\title{
CRISTIANE MARCELINO
}

\section{Qualidade de vida e coping religioso/espiritual em mães de crianças com cardiopatia congênita pré-operatórias}

Tese apresentada à Faculdade de Medicina da Universidade de São Paulo para obtenção do título de Doutor em Ciências

Programa de Cardiologia

Orientador: Prof. Dr. José Antonio Franchini Ramires

SÃO PAULO

2013 


\section{CRISTIANE MARCELINO}

\section{Qualidade de vida e coping religioso/espiritual em mães de crianças com cardiopatia congênita pré-operatórias}

Tese apresentada à Faculdade de Medicina da Universidade de São Paulo para obtenção do título de Doutor em Ciências

Programa de Cardiologia

Orientador: Prof. Dr. José Antonio Franchini Ramires

SÃO PAULO

2013 


\section{Dados Internacionais de Catalogação na Publicação (CIP)}

Preparada pela Biblioteca da

Faculdade de Medicina da Universidade de São Paulo

Creprodução autorizada pelo autor

\section{Marcelino, Cristiane}

Qualidade de vida e coping religioso/espiritual em mães de crianças com cardiopatia congênita pré-operatórias / Cristiane Marcelino. -- São Paulo, 2013.

Tese(doutorado)--Faculdade de Medicina da Universidade de São Paulo.

Programa de Cardiologia.

Orientador: José Antonio Franchini Ramires.

Descritores: 1.Qualidade de vida 2.Espiritualidade 3.Cardiopatia congênita 4.Adaptação psicológica 5.Mães 6.Questionários 7.Religião e psicologia 8.Acontecimentos que mudam a vida

USP/FM/DBD-075/13 


\section{DEDICATÓRIA}

A minha mãe, que com seu exemplo de pessoa e mãe, mesmo sozinha, nos criou com garra, amor e dedicação, sendo fundamental nesta obra, incentivando e ajudando-me a alcançar meus objetivos, a quem sem ela não vivo e sou eternamente grata;

Aos meus irmãos Marcilene, Lucilene e Neto que são as pilastras da minha vida;

Aos meus sobrinhos Bruno, Mariana, Lucas e Natália, meus maiores incentivos e filhos de coração;

Ao meu cunhado Pierre que muitas vezes fez o papel de pai ajudando com suas palavras de amor e força;

Ao Evandro Teixeira, mais que um amigo, um irmão, modelo de pessoa, competência e sucesso profissional, mostrando que tudo é possível se realmente queremos;

Ao meu pai, apesar da curta a permanência ao meu lado, sempre esteve presente através de sua imagem de homem e principalmente de ser humano;

A minha avó Bela e avô Edmundo, referência de força muitas vezes refletida em meus percalços;

A minha avó Glória e avô Alfredo que com a sua simplicidade e meiguice me ensinaram a ser uma pessoa melhor e descobrir o verdadeiro significado das coisas; 
A minha tia Nilce e tio Bertinho que direta e indiretamente me ajudaram com atitudes e palavras de incentivo;

As mães das crianças e as crianças com cardiopatia congênita, que enfrentando a doença dos filhos, foram prestativas e contribuíram significativamente para a realização desta obra, todas merecem meu respeito, amor e agradecimento; 


\section{AGRADECIMENTOS}

À Dr. José Antonio Franchini Ramires, meu orientador, pelo acolhimento, paciência, palavras de incentivo e principalmente pela sua orientação segura e ética. Minha total admiração, respeito e gratidão;

À Dr. Antonio Augusto Lopes pela sua ajuda incondicional e fundamental para a realização do trabalho;

À Neusa, assistente de direção da pós-graduação, que com sua serenidade e carinho sempre esteve ao meu lado, e cuja ajuda foi fundamental para concretização deste trabalho, agradeço a confiança depositada;

À Eva, Juliana e Tati, secretarias da pós-graduação que sempre me trataram com carinho e atenção,

À Glaucia e a Angélica, secretarias do Dr. Ramires que sempre me receberam com suas simpatias e dedicação;

Aos muito mais que amigos, Arthur e Renata Macedo, por todo apoio, acolhimento, obrigada pelo carinho e confiança;

À Dra Célia Sperandeo de Macedo, que sempre acreditou no meu potencial, Às minhas queridas amigas Sandra, Arlete, Nancy, Wana e Eliane e aos amigos Celso, Giuliano e Allysson que sempre estiveram ao meu lado em todos os momentos, dividindo alegrias e tristezas, serei eternamente grata; 
Às minhas amigas Adriana Ishi, Adriana Piesco, Mônica e Eneida, que a distância não impediu que participassem ativamente na minha vida, apoiando e incentivando nos momentos que mais precisei;

Aos meus grandes amigos e irmãos Amilton Franco e Celso Mucio pelo carinho, preocupação e apoio incondicional, jamais esquecerei; 
"Curar algumas vezes, aliviar freqüentemente, confortar sempre"

Dr. Harold G. Koenig 


\section{SUMÁRIO}

Lista de Abreviaturas

Lista de Tabelas

Lista de Gráficos

Resumo

Abstract

1 Introdução

1.1 Doenças Cardíacas Crônicas ......................................................................... 2

1.2 Estratégias de Enfrentamento diante de uma criança com cardiopatia congênita ........ 5

2 Métodos

2.1 Procedimento ................................................................................................. 15

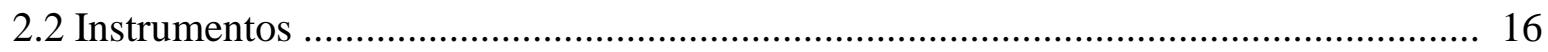

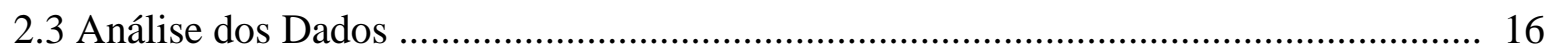

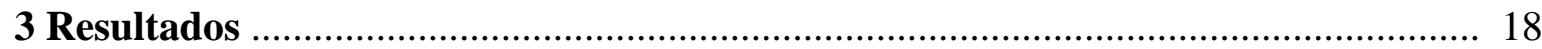

3.1 Caracterização da amostra ....................................................................... 18

3.1.1 Caracterização da amostra referente às crianças .............................................. 19

3.1.2 Caracterização da amostra referente às mães das crianças ................................. 19

3.2 Análise das características religiosas das mães ............................................... 21

3.3 Caracterização das freqüências de respostas às questões abertas coletas das mães ... 23

3.3.1 Caracterização das freqüências de respostas a questão: “O que é Deus para a sra.?”

3.3.2 Caracterização das freqüências de respostas a questão: "De que maneira a sra. acredita que a sua crença/religião ajudou ou não a enfrentar o problema com seu filho(a) ? " ...................................................................................................... 24 
3.3.3 Caracterização das freqüências de respostas a questão: "Baseado na sua experiência de que a crença/religião ajudou você a enfrentar estes problemas, que mensagem ou sugestão você daria a outras mães que se encontram nesta situação? ”.............................. 25

3.4 Análise de fidedignidade do instrumento WHOQOL - Breve na amostra .................. 25

3.5 Análise dos dados obtidos pelo Instrumento WHOQOL - Breve ............................... 26

3.6 Análise de fidedignidade do instrumento CRE - Abreviado na amostra ...................... 34

3.7 Análise dos dados obtidos pelo Instrumento CRE - Coping Religioso Espiritual ...... 35

3.7.1 Análise dos fatores positivos e negativos que compõem o instrumento CRE - Coping

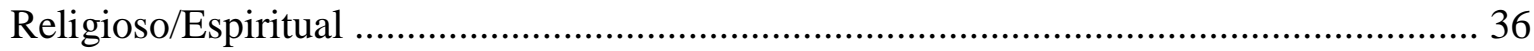

3.7.2 Análise das respostas das questões que compõem o instrumento CRE - Coping

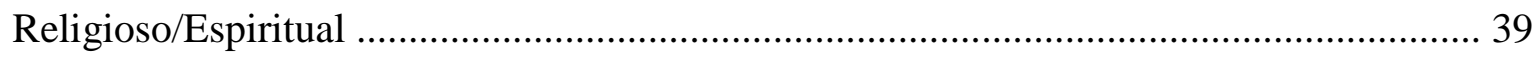

3.8 Correlação entre Qualidade de Vida x Coping Religioso/Espiritual ............................. 48

3.8.1 Analise das correlações entre os domínios do instrumento WHOQOL- Breve ....... 48 3.8.2 Analise das correlações entre fatores positivos $\mathrm{x}$ negativos do instrumento CRE Coping Religioso/Espiritual na amostra .......................................................................... 49

3.8.3 Correlação entre os instrumentos de Qualidade de Vida WHOQOL- Breve e o instrumento Coping Religioso/Espiritual na amostra .................................................... 50

3.9 Análise das variáveis: idade, estado civil, profissão, primeira cirurgia e já ter realizado outras cirurgias, tempo de internação, conhecimento sobre a data da cirurgia e grau de escolaridade de modo independente para o instrumento CRE - Coping Religioso/Espiritual 52

3.9.1 Análise das estratégias de Coping Religioso/Espiritual positivo e negativo x idade..52 3.9.2 Análise das estratégias de Coping Religioso/Espiritual positivo e negativo x estado civil 53

3.9.3 Análise das estratégias de Coping Religioso/Espiritual positivo e negativo x profissão 54

3.9.4 Análise das estratégias de Coping Religioso/Espiritual positivo e negativo x primeira cirurgia e pré-operatório com cirurgias anteriores ........................................................... 55 3.9.5 Análise das estratégias de Coping Religioso/Espiritual positivo e negativo x tempo de

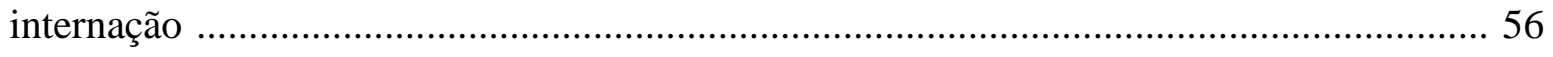


3.9.6 Análise das estratégias de Coping Religioso/Espiritual positivo e negativo x conhecimento sobre a data da cirurgia ................................................................. 56 3.9.7 Análise das estratégias de Coping Religioso/Espiritual positivo e negativo x grau de escolaridade 57

3 9.7.1 Análise da interação entre CRE positivo x idade das mães x já ter realizado cirurgias anteriores 58

3.10 Análise das variáveis: idade, estado civil, profissão, primeira cirurgia e já ter realizado outras cirurgias, tempo de internação, conhecimento sobre a data da cirurgia e grau de escolaridade de modo independente para o instrumento WHOQOL - Breve ................. 60

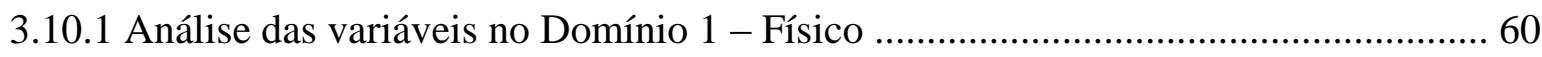

3.10.2 Análise das variáveis no Domínio 2 - Psicológico ............................................ 61

3.10.2.1 Análise da interação entre o Domínio 2 (Psicológico) x idade das mães ............. 62

3.10.3 Análise das variáveis no Domínio 3 - Relações Sociais ...................................... 62

3.10.3.1 Análise da interação entre o Domínio 3 (Relações Sociais) x profissão .............. 63

3.10.4 Análise das variáveis no Domínio 4 - Meio Ambiente ........................................ 64

3.10.4.1 Análise da interação entre o Domínio 4 (Meio Ambiente) x estado civil ........... 65

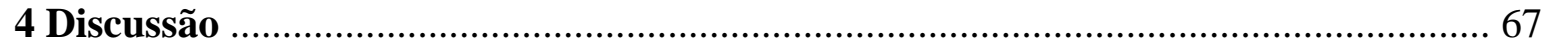

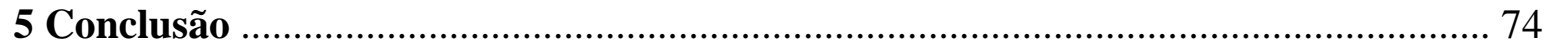

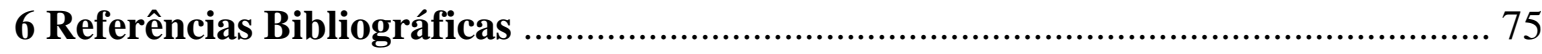

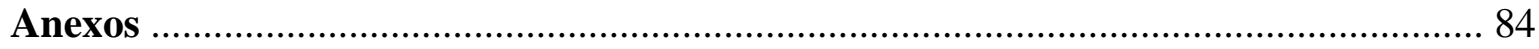

I - Termo de Consentimento Livre e Esclarecido ................................................. 84

II - Ficha de Dados Sociodemográficos ................................................................... 85

III- Questionário Qualitativo Semi Estruturado ..................................................... 88

IV- Instrumento de Avaliação de Qualidade de Vida WHOQOL - Abreviado .............. 90

VI - Escala de Coping Religioso-Espiritual Abreviada - Escala CRE-BREVE ............. 96 


\section{LISTA DE ABREVIATURAS}

AV: atrioventricular

VA: ventrículo arterial

D: direito

E: esquerdo

CIA: Comunicação interatrial

CIV: Comunicação interventricular

SOE: sem outra especificação

$\mathrm{RN}$ : recem nascido

UTI: Unidade de Terapia Intensiva

ER: Enfrentamento Religioso

CRE: Coping Religioso Espiritual

FACIT-SP: The Functional Assessment of Chronic Illness Therapy-Spiritual Well-Being Scale

WHOQOL-bref: World Health Organization of Quality of Life-Bref (Escala de qualidade de vida abreviada, com 26 questões)

WHOQOL-100: World Health Organization of Quality of Life-100 (Escala de qualidade de vida com 100 questões)

RCOPE: Religious Coping Scale.

CREN: Coping Religioso Espiritual Negativo

CREP: Coping Religioso Espiritual Positivo

BDI: Inventário Beck de Depressão

INCOR: Instituto do Coração

N1: Fator de reavaliação negativa de Deus

N2: Fator de posicionamento negativo frente a Deus

N3: Fator de insatisfação com o outro institucional

N4: Fator de reavaliação negativa do significado

P1: Fator de transformação de si e/ou de sua vida

P2: Fator de ações em busca de ajuda espiritual

P3: Fator de oferta de ajuda ao outro 
P4: Fator de posicionamento positivo frente a Deus

P5: Fator de ações em busca do outro institucional

P6: Fator de afastamento através de Deus, da religião e/ou espiritualidade

P7: Fator de busca pessoal de conhecimento espiritual

QV: Qualidade de vida

Q: questão

INV: invertido 


\section{LISTA DE TABELAS}

Tabela 1 - Características da amostra relativa às crianças

Tabela 2 - Características da amostra relativa às mães das crianças

Tabela 3 - Caracterização Religiosa/Espiritual das mães das crianças com cardiopatia congênita

Tabela 4 - Freqüência das respostas da questão: “O que é Deus para a sra.?” 24

Tabela 5 - Freqüência das respostas da questão: "De que maneira a sra. acredita que a sua crença/religião ajudou ou não a enfrentar o problema com seu filho?" 24

Tabela 6 - Frequiência das respostas da questão: “Baseado na sua experiência de que a crença/religião ajudou você a enfrentar estes problemas, que mensagem ou sugestão você daria a outras mães que se encontram nesta situação?” 25

Tabela 7 - Análise de Alpha de Cronbach nos domínios no WHOQOL- Breve 26

Tabela 8 - Distribuição das médias entre os domínios do WHOQOL - Breve na amostra 26

Tabela 9 - Distribuição das freqüências das questões de QV nos domínios 28

Tabela 10 - Análise de Alpha de Cronbach no CRE - Breve 35

Tabela 11 - Frequiência das respostas à questão que pede a descrição da situação que a mãe viveu de maior estresse nos últimos três anos 35

Tabela 12 - Distribuição das médias entre os fatores positivos e negativos do CRE - Breve 36 
Tabela 13 - Distribuição das médias dos fatores do CRE - Breve.

Tabela 14 - Distribuição das questões do CRE - Breve de acordo com os fatores 40

Tabela 15 - Correlação de Pearson entre domínios da QV e CRE 50

Tabela 16 - Caracterização do valor de p no teste de nulidade das correlações de Pearson entre domínios da QV e CRE 51

Tabela 17 - Descrição das médias dos escores de coping religioso/espiritual positivo por faixa etária 53

Tabela 18 - Descrição das médias dos escores de coping religioso/espiritual negativo por faixa etária 53

Tabela 19 - Descrição das médias dos escores de coping religioso/espiritual positivo e estado civil 54

Tabela 20 - Descrição das médias dos escores de coping religioso/espiritual negativo e estado civil 54

Tabela 21 - Descrição das médias dos escores de coping religioso/espiritual positivo e profissão 54

Tabela 22 - Descrição das médias dos escores de coping religioso/espiritual negativo e profissão 55

Tabela 23 - Descrição das médias dos escores de coping religioso/espiritual positivo e primeira cirurgia x pré-operatório com cirurgias anteriores 55 
Tabela 24 - Descrição das médias dos escores de coping religioso/espiritual negativo e primeira cirurgia x pré-operatório com cirurgias anteriores 55

Tabela 25 - Descrição das médias dos escores de coping religioso/espiritual positivo e tempo de internação 56

Tabela 26 - Descrição das médias dos escores de coping religioso/espiritual negativo e tempo de internação 56

Tabela 27 - Descrição das médias dos escores de coping religioso/espiritual positivo e conhecimento sobre a data da cirurgia 57

Tabela 28 - Descrição das médias dos escores de coping religioso/espiritual negativo e conhecimento sobre a data da cirurgia 57

Tabela 29 - Descrição das médias dos escores de coping religioso/espiritual positivo e grau de escolaridade 57

Tabela 30 - Descrição das médias dos escores de coping religioso/espiritual negativo e grau de escolaridade 58

Tabela 31 - Descrição do escore de QV (Domínio 1 - físico) e teste F da ANOVA para comparação de médias 60

Tabela 32 - Descrição do escore de QV (Domínio 2 - psicológico) e teste F da ANOVA para comparação de médias

Tabela 33 - Descrição do escore de QV (Domínio 3 - relações sociais) e teste F da ANOVA para comparação de médias 63 
Tabela 34 - Descrição do escore de QV (Domínio 4 - meio ambiente) e teste F da ANOVA

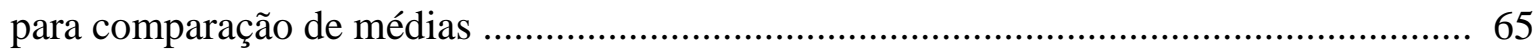




\section{LISTA DE GRÁFICOS}

Gráfico 1 - Freqüência dos Escores x Domínios do WHOQOL - Breve............................ 34

Gráfico 2 - Freqüência das Fatores x Escores do CRE - Breve ..................................... 37

Gráfico 3 - Comparação entre CRE Positivo x CRE Negativo ........................................ 38

Gráfico 4 - Razão entre os fatores (CREN/CREP) ............................................... 39

Gráfico 5 - Correlação entre os domínios do WHOQOL - Breve na amostra ................... 48

Gráfico 6 - Correlação entre os fatores do CRE - Breve na amostra ............................. 49

Gráfico 7 - Correlação entre WHOQOL - Breve x CRE positivo ........................... 52

Gráfico 8 - Interação entre CRE positivo x faixa etária x já ter realizado outras cirurgias 59

Gráfico 9 - Média de QV (Domínio 2 - Psicológico) x faixa etária ................................ 62

Gráfico 10 - Interação entre QV (Domínio 3 - Relações Sociais) x profissão ................. 64

Gráfico 11 - Interação entre QV (Domínio 4 - Meio Ambiente) x estado civil ............... 66 


\section{RESUMO}

Marcelino, Cristiane. Qualidade de vida e coping religioso/espiritual em mães de crianças com cardiopatia congênita pré-operatórias [tese]. São Paulo: Faculdade de Medicina, Universidade de São Paulo; 2013.

O presente estudo teve como objetivo avaliar se as mães de crianças com cardiopatia congênita utilizam a espiritualidade/religiosidade como estratégia de enfrentamento e se utilizam de forma negativa ou positiva. Também avaliou a qualidade de vida destas mães e suas associações com as estratégias de enfrentamento além das variáveis: idade, estado civil, profissão, primeira cirurgia e já ter realizado outras cirurgias, tempo de internação, conhecimento sobre a data da cirurgia e grau de escolaridade. Foi aplicado um questionário semi estruturado com o objetivo de obter dados referentes à religiosidade/espiritualidade, o instrumento que avalia a qualidade de vida WHOQOL-bref (World Health Organization Quality of Life - versão abreviada) e o instrumento CRE (Coping Religioso Espiritual) que avalia aspectos relacionados à: religiosidade/espiritualidade. A amostra foi composta por 48 mães de crianças portadoras de cardiopatia congênita que encontravam-se internadas aguardando procedimento cirúrgico. O presente estudo demonstrou através dos achados descritos que ser mãe de uma criança portadora de doença crônica, assim como a cardiopatia congênita, é um fato estressante devido às freqüentes internações, mudança na rotina, ansiedade com a cirurgia, medo da perda, entre outros. Estas mães diante desses eventos utilizam estratégias religiosas positivas e que estas estão correlacionadas com qualidade de vida.

Descritores: 1. qualidade de vida 2. espiritualidade 3. cardiopatia congênita 4. adaptação psicológica 5. mães 6. questionários 7. religião e psicologia 8. acontecimentos que mudam a vida 


\begin{abstract}
Marcelino, Cristiane. Quality of life and coping religious or spiritual mothers of children with congenital heart disease preoperative [thesis]. Sao Paulo: Faculty of Medicine, University of São Paulo; 2013.

The present study aimed to evaluate whether mothers of children with congenital heart disease use spirituality or religiosity as a coping strategy and are used negatively or positively. We also evaluated the quality of life of these mothers and their associated coping strategies besides their variables: age, marital status, occupation, first surgery and other surgeries that were already performed, length of stay, knowledge of the date of surgery and schooling . We applied a semi-structured questionnaire in order to obtain data on religiosity or spirituality, the instrument that assesses the quality of life WHOQOLBREF (World Health Organization Quality of Life - short version) and the instrument CRE (Religious Coping Spiritual) which evaluates aspects related to: religiosity or spirituality. The sample consisted of 48 mothers of children with congenital heart disease who were hospitalized awaiting surgery. The present study demonstrated by the findings reported to be a mother of a child with chronic illness, as well as congenital heart disease, it is a stressful fact due to frequent hospitalizations, change in routine, anxiety with surgery, fear of loss, among others. These mothers before these strategies use positive religious events and these are correlated with the quality of life.
\end{abstract}

Descriptors: 1. quality of life 2. spirituality 3. congenital heart disease 4. coping 5 . mothers 6. questionnaires 7. religion and psychology 8. life change events 


\section{Introdução}

Vários estudos traduzem “coping” como enfrentamento", ou seja, um conjunto de esforços cognitivos e comportamentais, utilizado pelos indivíduos com o objetivo de lidar com demandas específicas, internas ou externas, que surgem em situação de estresse e são interpretadas como sobrecarregando ou excedendo seus recursos pessoais ${ }^{2}$.

Segundo o modelo de Folkman e Lazarus, o “coping” é denominado um processo ou uma interação entre o indivíduo e o ambiente, cuja função é a de tentar administrar a situação estressora e não controlar ou dominar a mesma. Os processos de “coping” pressupõem a noção de como o fenômeno é percebido, interpretado e cognitivamente representado na mente do indivíduo, constituindo-se, deste modo, em mobilização de esforços cognitivos e comportamentais para administrar as demandas internas ou externas que surgem da sua interação com o ambiente ${ }^{3}$.

As estratégias de coping podem ser classificadas, segundo sua função, como aquelas focadas na emoção ou as focadas no problema ${ }^{4,3}$.

As estratégias focadas na emoção refere-se a um esforço cognitivo com o objetivo de regular a resposta emocional associada ao estresse, ou seja, reduzindo a sensação desagradável e modificando o estado emocional. As estratégias focadas no problema são esforços dirigidos para a definição do problema, na busca de alternativas onde envolvem escolhas e ação sobre o problema, ou seja, busca agir na origem do estresse, alternado o problema entre a pessoa e o evento causador de tensão ${ }^{5}$.

Em situações consideradas inalteradas como no caso de uma doença crônica, o "coping" focalizado na emoção tende a ser mais utilizado ${ }^{4}$.

Estas estratégias estão ligadas a fatores situacionais, que podem mudar de momento para momento, durante o estágio de uma situação estressante ${ }^{4}$.

O uso de estratégias de "coping” focalizado no problema ou na emoção depende de uma avaliação da situação estressora na qual o sujeito encontra-se envolvido.

O "coping” focalizado no problema é mais empregado em situações avaliadas como modificáveis, enquanto que o focalizado na emoção tende a ser mais utilizados nas situações 
avaliadas como inalteráveis ${ }^{4}$, podendo variar em resposta a diferentes tipos de estresse ou diferentes momentos no tempo ${ }^{3}$.

Ambas as estratégias de “coping” são usadas durante praticamente todos os episódios estressantes, variando sua eficácia de acordo com o tipo de evento estressor ${ }^{6}$.

Uma terceira estratégia, focalizada nas relações interpessoais, no qual o sujeito busca apoio nas pessoas do seu círculo social para a resolução da situação estressante tem sido estudada mais recentemente com o objetivo de entender o papel da personalidade e dos fatores situacionais na escolha dessas diferentes estratégias ${ }^{7,8}$.

\subsection{Doenças Cardíacas Crônicas na Infância}

Não há dúvidas quanto ao impacto que uma doença crônica causa na criança, na sua família e em todos os setores da vida: familiar, financeiro, social e pessoal ${ }^{9}$. Assim sendo, a doença crônica pode ser vista como um agente estressor que afeta não apenas a criança como também a sua família $^{10}$, tornando-se uma vivência marcante e de grande impacto na vida das pessoas. A separação da família, a mudança na rotina, entre outros fatores geram desgaste não apenas físico, mas, também psicológico para a criança e os familiares, despertando sentimentos como: medo, insegurança, depressão ${ }^{11}$. Em estudo realizado com mães de crianças portadoras de cardiopatia congênita com o objetivo de compreender a vivência das mesmas sentimentos como: desespero, culpa e insegurança foram descritos como presentes ${ }^{12}$.

Define-se doença crônica como a condição que afeta as funções do indivíduo em suas atividades diárias por mais de três meses, causa hospitalizações durante pelo menos um mês por ano ou requer o uso de dispositivos especiais de adaptação, apresentando uma elevada prevalência de implicações para o desenvolvimento da própria criança e para a sua relação familiar $^{13,14}$.

Entre as doenças crônicas da infância estão as cardiopatias congênitas ${ }^{15}$, a fibrose cística ${ }^{16}$, a doença hepática ${ }^{17}$, e o câncer ${ }^{18}$. E as cardiopatias congênitas ocorrem em aproximadamente 810 indivíduos por 1000 nascidos vivos, abrangendo 50\% das causas de óbitos por malformações congênitas e $15 \%$ dos óbitos infantis ${ }^{19 .}$. 
Leite $^{20}$, através da revisão de 1591 necropsias realizadas de janeiro de 1996 a dezembro de 2007, demonstrou que ainda é alta a prevalência de anomalias cardíacas congênitas e o índice de mortalidade associada a essas anomalias elevada, constituindo-se na segunda causa de morte infantil no Brasil. Assim sendo, reveste-se de grande importância, uma vez que são inúmeras as possibilidades de defeitos e de alterações funcionais, acarretando desde simples modificações hemodinâmicas até situações das mais complexas ${ }^{21}$. Cerca de 20-30\% das crianças morrem no primeiro mês de vida por insuficiência cardíaca ou crises de hipóxia ${ }^{19}$.

As cardiopatias congênitas acometem o coração e/ou os vasos sanguíneos ainda em seu desenvolvimento intra-uterino, podendo ser identificada no período gestacional, ao nascimento, ou mesmo na primeira infância podendo ser tratadas clinicamente e cirurgicamente ${ }^{22}$.

Quanto à classificação da gravidade, as cardiopatias congênitas podem progredir favoravelmente com o crescimento físico da criança sendo corrigidas espontaneamente, até casos mais graves, que colocam a vida em risco obrigando a tratamentos clínicos e/ou cirúrgicos sem os quais a criança morrerá nos primeiros anos de vida ${ }^{23,24}$.

A classificação das cardiopatias congênitas deu-se em 1936 quando foram subdivididas em: cianóticas e acianóticas, através da publicação da tabela de Abbott, tornando-se assim um marco para o seu diagnóstico clínico, classificação esta a mais aceita no meio médico até hoje ${ }^{25,26}$.

As cardiopatias congênitas acianóticas ocorrem por um desvio de sangue da esquerda para a direita, envolve funções das paredes das câmaras cardíacas através da obstrução das mesmas, e ainda por anomalias das artérias coronárias; enquanto que nas cardiopatias congênitas cianóticas ocorre o desvio de sangue da direita para a esquerda, consequiência de lesões obstrutivas de câmaras cardíacas direitas acompanhadas de comunicação intracavitária ou quando levam à dessaturação do fluxo sanguíneo por mistura da circulação sistêmica com a circulação pulmonar ou por discordância da conexão ventrículo-arterial ${ }^{27}$. Esse processo resulta em oxigenação reduzida de sangue dando a pele uma coloração azulada generalizada ou nas extremidades do corpo, alterando a aparência das crianças ${ }^{28,29}$.

Utilizando-se do sistema de nomenclatura único proposto pelo Instituto do Coração podemos classificar os defeitos congênitos como:

1- Anomalias de situs: situs inverso, situs ambíguo,

2- Anomalias do retorno venoso: veias sistêmicas, veias pulmonares,

3- Anomalias da conexão AV: conexão AV discordante, conexão AV univentricular (UV), 
4- Anomalias da conexão VA: conexão VA discordante (transposição das grandes artérias), via de saída única, dupla via de saída ventricular,

5- Defeitos septais: comunicação interatrial, comunicação interventricular, defeito do septo atrioventricular,

6- Anomalias do coração D: tetralogia de Fallot, atresia pulmonar, lesões da via de saída, anamalia da valva tricúspide,

7- Anomalias do coração E: lesões da via de saída, síndrome da hipoplasia do coração E, anomalias da valva mitral,

8- Anomalias das artérias torácicas: anomalias da aorta, persistência do canal arterial, janela aorto-pulmonar, anomalias das artérias pulmonares, anomalias das artérias coronárias,

9- Miscelânea: aneurisma do Átrio Direito, aneurisma do Átrio Esquerdo, aneurisma de Ventrículo Direito, Aneurisma de Ventrículo Esquerdo, aneurisma do septo atrial (fossa oval), Aneurisma do septo membranoso, CIA não restritiva, CIA restritiva, Cisto do pericárdio, CIV não restritiva, CIV restritiva, Coração normal, Criss-Cross, Doença de depósito com comprometimento miocárdico, Doença Veno-oclusiva pulmonar, Ectopia do Coração (fora da cavidade torácica), Estenose aórtica valvar, Estenose pulmonar valvar, Estenose sub-aórtica, Estenose sub-pulmonar, Estenose supra-valvar aórtica, estenose supra-valvar pulmonar, Estenose valva AV Direita, Estenose valva AV esquerda, Fístula arteriovenosa cerebral, Fístula arteriovenosa hepática, Fístula arteriovenosa pulmonar, Fístula arteriovenosa SOE, Hipertensão Pulmonar Persistente do RN, Hipoplasia de ventrículo direito, Hipoplasia do ventrículo esquerdo, Hipoplasia valva AV Direita, Hipoplasia valva AV Esquerda, Imperfuração valva aórtica, Imperfuração valva AV Direita, Imperfuração valva AV Esquerda, Imperfuração valva pulmonar, Insuficiência valva AV Direita, Insufuciência valva AV Esquerda, Justaposição de aurículas, Miocardiopatia hipertrófica não obstrutiva, Miocardiopatia hipertrófica obstrutiva, Miocardiopatia restritiva, Pseudoaneurisma de Ventrículo Direito, Pseudoaneurisma de Ventrículo Esquerdo, Síndromes genéticas, Tumor cardíaco no Átrio Direito, Tumor cardíaco no Átrio Esquerdo, Tumor cardíaco no Ventrículo Direito, Tumor cardíaco no Ventrículo Esquerdo, Tumor no pericárdio e Ventrículo Súpero-Inferior.

Esta lista foi dividida em 3 níveis hierárquicos. O primeiro representa os passos da análise seqüencial segmentar (itens 1 a 4), acrescidos por outros grupos de anomalias septais, do coração direito, do coração esquerdo e das artérias torácicas (itens 5 a 8), não contemplados pela análise 
segmentar e o item miscelânia (item 9) que não tinham possibilidade de serem agrupados nos itens anteriores ${ }^{30}$.

1.2 Estratégias de Enfrentamento diante de uma criança com cardiopatia congênita

As terapêuticas nos casos de doenças graves vêm procurando garantir o prolongamento da vida, entretanto o impacto dessas doenças e dos tratamentos é difícil de ser enfrentado tanto pela criança como por sua família ${ }^{15,31}$.

Segundo Kohlsdorf ${ }^{32}$, várias pesquisas que investigam como os cuidadores lidam com a enfermidade pediátrica apontaram que estes sofrem uma grande quantidade de eventos estressores, que interferem na dinâmica familiar e social ${ }^{33}$.

O processo de tratamento da cardiopatia congênita é permeado por várias internações, podendo ser vivenciada como uma situação estressante pelos acompanhantes ${ }^{34}$, sendo que tanto a mãe quanto o pai podem ser bastante atingidos ${ }^{35.24}$.

Pesquisa realizada com 57 familiares de crianças com cardiopatia congênita demonstrou que, para casais jovens de classe social média baixa em fase de estruturação familiar, o nascimento de uma criança doente e o evento da cirurgia gera estresse, sendo que alguns evitavam falar do futuro ${ }^{36}$. Estudo realizado com 44 acompanhantes de crianças com cardiopatias congênitas internadas em pré e pós-operatório demonstrou que as estratégias de enfrentamento mais utilizadas foram: resolução de problemas, fuga e esquiva e reavaliação positiva ${ }^{34}$.

A confirmação do diagnóstico, as mudanças no estilo de vida tanto do paciente quanto da família, o medo da morte, consultas regulares, absenteísmo escolar, adesão a nova terapêutica medicamentosa e seus efeitos colaterais, hospitalizações freqüentes tanto para realização de exames quanto procedimentos invasivos, limitações das atividades físicas, a permanência na UTI no pós-operatório, a privação de sono, barulho de aparelhos, separação entre a criança e família, além da dependência são fatores estressores que causarão as mais diversas alterações emocionais $^{14,37,38,29}$. Yali e Lobel $^{39}$, em estudo realizado com 167 gestantes de alto risco, associando coping, gestação e estresse identificaram altos níveis de estresse sendo que, frente às demandas e desafios, a religião e a reavaliação positiva foram estratégias mais usadas. 
Estudos que avaliaram nível de estresse e estratégias de enfrentamento em mães de crianças com cardiopatia congênita identificaram que as estratégias mais utilizadas foram: a busca da prática religiosa, resolução de problemas, suporte social, fuga/esquiva ${ }^{29,40}$.

Estratégias cognitivas ou comportamentais para lidar com eventos estressores, advindas da religião ou da espiritualidade da pessoa, são denominadas de enfrentamento religioso (ER), assim, quando as pessoas se apóiam na religião para lidar com o estresse, considera-se que ocorre o coping religioso - espiritual (CRE) ${ }^{41,42}$.

Estudos indicam que as crenças religiosas estão associadas com melhor saúde física ${ }^{43,44}$, mental $^{45,46}$ e à melhor qualidade de vida ${ }^{47}$. A religiosidade tem sido apontada como uma das dimensões da qualidade de vida ${ }^{48}$.

Considerando-se que a Organização Mundial de Saúde $^{49}$ conceitua saúde como um completo bem estar físico, mental, social e não apenas a ausência de doença ou enfermidade, o foco na doença cederia espaço às características adaptativas como resiliência, esperança, sabedoria, criatividade, coragem e espiritualidade ${ }^{48}$.

A religiosidade atribui um significado a doença, porém pode carregar consigo um conceito de culpa e castigo, sendo necessário e importante que os profissionais da área da saúde estejam atentos às crenças e aos valores que as famílias disponibilizam para lidar com a doença, auxiliando no desenvolvimento de estratégias de enfrentamento eficientes e menos disfuncionais $^{50}$.

A espiritualidade e a religiosidade como estratégias de enfrentamento têm sido bastante investigadas nos contextos de oncologia pediátrica ${ }^{51,52}$. Em estudo realizado com cuidadores de crianças e adolescentes analisando as estratégias de enfrentamento, a estratégia focalizada em práticas religiosas atingiu as médias mais elevadas ${ }^{52}$.

A religiosidade tem sido medida de diferentes maneiras, geralmente através da afiliação religiosa, prática e frequiência aos cultos. No entanto, por se tratar de algo tão complexo, uma única variável limita o estudo ${ }^{53}$.

É importante salientar que espiritualidade e religiosidade não possuem o mesmo significado. A religião está diretamente ligada a uma doutrina específica, com práticas religiosas e rituais, enquanto a espiritualidade não está necessariamente vinculada a uma crença ou prática religiosa e sim a uma orientação filosófica que produz sentimentos de amor, fé e esperança ${ }^{54,55}$. 
Embora distintas conceitualmente, a espiritualidade e a religiosidade estão intimamente imbricadas, uma vez que a espiritualidade define-se como a essência de uma pessoa, assim como a busca de significado e propósito de vida, enquanto a religiosidade pode ser considerada a expressão da própria espiritualidade manifesta através de rituais, dogmas e doutrinas ${ }^{56,57,58}$.

A análise de 225 estudos investigando a relação do CRE com saúde física verificou resultados benéficos do envolvimento religioso em relação à dor, debilidade física, doenças do coração, pressão sanguínea, infarto as funções imune e neuroendócrina, doenças infecciosas, câncer e mortalidade na maioria desses estudos ${ }^{45}$.

Já em outros estudo, com 850 pesquisas examinando relação do CRE com saúde mental, a maioria encontrou associação do envolvimento religioso com maiores níveis de satisfação de vida, bem estar, senso de propósito e significado de vida ${ }^{43}$.

Ferriss $^{59}$ encontrou a variável felicidade associada à freqüência/presença em serviços religiosos e concluiu que estas organizações contribuem para a qualidade de vida devido à integração da comunidade, e que a religião pode proporcionar um propósito na vida que promova bem estar ${ }^{59}$.

Na validação do instrumento FACIT-SP (The Functional Assessment of Chronic Illness Therapy-Spiritual Well-Being Scale) em amostra multiétnica de 1617 participantes, cuja média de idade era 54,6 anos, foi encontrado associação positiva entre qualidade de vida e bem estar espiritual em diferentes populações ${ }^{60}$.

Vários estudos apontam os benefícios relacionados à espiritualidade, religiosidade e ao ato de $\operatorname{orar}^{61}$ em pacientes oncológicos ${ }^{62,63}$, em famílias de crianças com insuficiência renal crônica $^{57}$, em adultos com doenças crônicas ou que estão passando por eventos estressantes ${ }^{64,65}$.

Quando apontamos as estratégias de coping religioso espiritual e sua associação com qualidade de vida ${ }^{66}$, estas podem ser positivas (proporcionam efeito benéfico ao praticante) e negativas (delega a Deus a resolução dos problemas e avalia o estressor como punição divina) ${ }^{48}$. Desta maneira os autores concluíram que a religião/espiritualidade pode ser fonte de alívio ou desconforto e solução de problemas bem, como causa de estresse, dependendo da relação da pessoa com a mesma ${ }^{67}$. É freqüente encontrar nos relatos de pacientes alusão a causalidade religiosa para suas doenças ou curas ${ }^{68}$.

Uma vez que a literatura aponta que o nascimento de uma criança com doença crônica e suas consequiências é um fator que gera estresse nos pais e que estratégias de enfrentamento 
baseadas na religião e espiritualidade têm ajudado em diversas doenças associadas à maior qualidade de vida, o presente estudo teve como objetivo avaliar se as mães de crianças portadoras de cardiopatia congênita utilizam da religiosidade/espiritualidade para lidar com o estresse gerado pelo diagnóstico, internação, intervenções e cirurgia, e se utilizam de maneira positiva ou negativa. Também tem como objetivo avaliar a qualidade de vida dessas mães através do WHOQOL-Breve e suas possíveis relações com Coping Religioso Espiritual através do instrumento CRE-breve além de analisar as possíveis correlações das variáveis: idade, estado civil, profissão, ter a experiência de cirurgias anteriores, tempo de internação, conhecimento sobre a data da cirurgia e grau de escolaridade com os instrumentos: WHOQOL-Breve que avalia qualidade de vida (QV) e “coping” religioso espiritual (CRE). 


\section{Métodos}

A pesquisa foi realizada no Instituto do Coração, do Hospital das Clínicas da Faculdade de Medicina da Universidade de São Paulo, na Unidade de Cardiopatia Congênita. O período de coleta dos dados se deu de junho a dezembro de 2011. Trata-se de um estudo descritivo, exploratório, de corte transversal e abordagem quantitativa.

A seleção da amostra seguiu os seguintes critérios:

Critérios de inclusão: mães de crianças portadoras de cardiopatia congênita que aguardavam procedimento cirúrgico independente de já terem realizados algum procedimento cirúrgico anterior, ou seja, pré-operatórios. Quanto ao sexo das crianças este foi aleatório.

Critério de exclusão: mães de crianças com dificuldade de compreensão dos instrumentos, que se negassem a participar do estudo e mães de crianças pós-operatórias.

Foram consideradas as mães de crianças que iriam realizar o primeiro procedimento cirúrgico e também as mães de crianças que já tinham se submetido a cirurgias anteriores, porém na ocasião da coleta aguardavam novo procedimento cirúrgico.

Após a assinatura do termo de consentimento livre e esclarecido (Anexo I), foram aplicados três instrumentos: um questionário semi-estruturado para a coleta de dados sócio-econômicos (Anexo II) e religiosos (Anexo III), o instrumento que avalia a qualidade de vida WHOQOL-Bref (World Health Organization Quality of Life), versão abreviada do WHOQOL-100 (Anexo IV) e a escala CRE (Coping Religioso Espiritual) (Anexo V).

Em relação a escala CRE (Coping Religioso-Espiritual), esta foi validada no Brasil por Panzini $^{5,}{ }^{69}$, em estudo transversal, que compreendeu duas fases: a tradução, adaptação e teste piloto e na segunda fase: o teste de campo que contou com uma amostra final de 616 participantes, de ambos os sexos e instituições religiosas de diversas crenças, esta foi validada com base na escala norte-americana RCOPE (Religious Coping Scale) ${ }^{70}$.

Foram modificados 28 itens, em relação à RCOPE original, 42 foram descartados e 33 foram acrescentados, resultando numa escala com 96 itens. Tais modificações sofridas fizeram com que fosse renomeada para "Escala de Coping Religioso Espiritual (Escala CRE)". Após uma revisão nas análises, a dimensão de Coping Religioso Espiritual positivo da escala CRE 
ficou com 66 itens distribuídos em oito fatores, deixando a escala com um conjunto de 87 itens, sendo que a sua versão abreviada é composta por 49 itens 5.

Quanto a escala CRE, sua instrução fornece os conceitos de coping religioso espiritual e de estresse, pede a descrição breve da situação de maior estresse que a pessoa vivenciou nos últimos 3 anos e solicita que a pessoa responda o quanto fez ou não o que está escrito em cada item para lidar com a situação estressante. As respostas são dadas em escala Likert de cinco pontos (1 nem um pouco a 5 - muitíssimo) ${ }^{69}$. Esta escala é composta por questões que compreendem aspectos negativos e positivos do uso da religiosidade/espiritualidade possibilitando, de acordo com as respostas, identificar a predominância de uma ou de outra.

A escala CRE considera quatro índices principais para a avaliação do indivíduo: dois dimensionais e dois gerais. Os dois primeiros dizem respeito a cada uma das dimensões da escala, e são importantes para indicar os diferentes tipos de CRE praticados pelo avaliado, bem como seus respectivos níveis, configurando-se como medidas básicas desta escala. Os índices denominados gerais integram todas as informações providas pela escala relacionando as duas primeiras medidas, a fim de obter índices gerais utilizando todos os itens da Escala CRE. Assim, apontam para a interação entre as medidas básicas, mostrando um perfil sobre o conjunto dos comportamentos realizados/avaliados ${ }^{5}$.

A escala CRE versão abreviada possui 34 itens (questões 1, 2, 4 - 6, 8, 10, 12, 14 - 18, 20, 21, 24 - 27, 29 - 31, 34, 35, 36, 38 - 40, 42, 43, 45 - 47, 49), de coping positivos. Os itens de coping negativos que compõem esta versão abreviada são as seguintes questões: 3, 7, 9, 11, 13, $19,22,23,28,32,33,37,41,44,48$, totalizando 15 itens.

Os fatores que compõem os itens do coping positivo são sete:

P1- Transformação de si e/ou de sua vida

P2- Ações em busca de ajuda espiritual

P3- Oferta de ajuda ao outro

P4- Posicionamento positivo frente a Deus

P5- Busca pessoal de crescimento espiritual

P6- Ações em busca do outro institucional,

P7- Busca pessoal de conhecimento espiritual. 
Os fatores que compõem os itens negativos são quatro:

N1- Reavaliação negativa de Deus,

N2- Posicionamento negativo frente a Deus,

N3- Reavaliação negativa do significado

N4- Insatisfação com o outro institucional.

Assim sendo, a escala CRE-Breve possui 49 itens divididos em duas dimensões: CRE positivo e CRE negativo. O CRE positivo é composto de 34 ítens e 7 fatores, enquanto o CRE negativo é composto de 15 itens e quatro fatores.

Para a análise dos participantes através da escala CRE foram criados índices a partir de

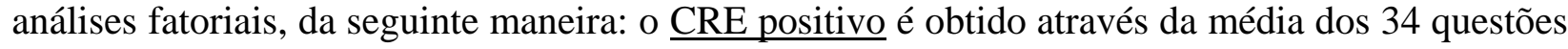
da Dimensão CREP, o CRE negativo obtido através da média das 15 questões da Dimensão CREN.

O CRE Total: indica a quantidade total de CRE's praticado pelo avaliado, através da média entre o Índice CRE Positivo e a média das respostas invertidas aos itens CREN (CRE Negativo Invertido); a Razão CREN/CREP: revela a percentagem de CRE Negativo utilizado em relação ao CRE Positivo, através da divisão simples entre os índices básicos ${ }^{69}$.

Em recente estudo para validação da versão brasileira do instrumento de qualidade de vida/espiritualidade, religião e crenças pessoais ${ }^{71}$, a escala foi aplicada considerando os seguintes dados para sua análise: resultados de 1 a 5 para utilização de CRE (nenhuma ou irrisória (1,00 a 1,50); baixa (1,51 a 2,50); média (2,51 a 3,50); alta (3,51 a 4,50); altíssima (4,51 a 5,00). Consistência interna alfa $=0,93(\mathrm{CRE}$ Positivo alfa $=0,95$; $\mathrm{CRE}$ Negativo alfa $=0,79)$ e entre 0,60 e 0,89 para os fatores.

A escala WHOQOL (World Health Organization Quality of Life Instrument - Breve) avalia a qualidade de vida. A versão abreviada do WHOQOL surgiu devido à necessidade de um instrumento menos extenso para estudos nos quais a qualidade de vida é apenas uma das variáveis $^{72}$.

Para validação do WHOQOL, versão abreviada foram aplicados o WHOQOL-bref, o BDI (Inventário de Beck para a depressão) e o BHS (Escala de Desesperança de Beck) numa pesquisa realizada com 300 indivíduos na cidade de Porto Alegre, sendo 250 pacientes de um hospital de clínicas e 50 voluntários-controle. $\mathrm{O}$ instrumento apresentou um bom desempenho psicométrico aliado a uma praticidade de uso $^{72}$. 
O WHOQOL versão abreviada é composto por 26 questões fechadas que obtiveram desempenho psicométrico satisfatório do WHOQOL-100, duas questões são perguntas gerais de qualidade de vida e as 24 restantes distribuídos em 4 domínios: físico (7 ítens), psicológico (6 itens), relações sociais (três itens) e meio ambiente (8 itens) ${ }^{72,73}$.

Domínio físico: composto pelas seguintes facetas:

Dor e desconforto,

Energia e fadiga,

Sono e repouso,

Mobilidade,

Atividades da vida cotidiana,

Dependência de medicação ou de tratamentos,

Capacidade de trabalho.

\section{Domínio psicológico:}

Sentimentos positivos,

Pensar, aprender, memória e concentração,

Auto-estima,

Imagem corporal e aparência,

Sentimentos negativos,

Espiritualidade/religião/crenças pessoais.

\section{Domínio relacões sociais:}

Relações pessoais,

Suporte (apoio) social,

Atividade sexual. 


\section{Domínio meio ambiente:}

Segurança física e proteção,

Ambiente no lar,

Recursos financeiros,

Cuidados de saúde e sociais: disponibilidade e qualidade,

Oportunidades de adquirir novas informações e habilidades,

Participação em/e oportunidades de recreação/laser,

Ambiente físico (poluição/ruído/trânsito/clima),

Transporte.

\section{As questões gerais sobre qualidade de vida e percepcão geral da saúde são:}

como o entrevistado avalia a sua qualidade de vida (questão 1)

grau de satisfação com a sua saúde (questão 2$)^{74}$.

A escala WHOQOL é do tipo Likert e compreende as escalas de intensidade (nada extremamente), capacidade (nada - completamente), frequência (nunca - sempre) e avaliação (muito insatisfeito, muito satisfeito, muito ruim, muito bom) com escores que variam de um a cinco pontos ${ }^{75}$.

As questões que compõem o Domínio I (físico) são:

- Em que medida você acha que sua dor (física) impede você de fazer o que você precisa? (questão 3)

- Você tem energia suficiente para seu dia-a-dia? (questão 10)

- Quão satisfeito (a) você esta com o seu sono? (questão 16)

- Quão bem você é capaz de se locomover? (questão 15)

- Quão satisfeito (a) você esta com a sua capacidade de desempenhar as atividades do seu dia-adia? (questão 17)

- O quanto você precisa de algum tratamento para levar sua vida diária? (questão 4)

- Quão satisfeito (a) você esta com sua capacidade para o trabalho? (questão 18) 
As questões que compõem o Domínio II (psicológico) são:

- O quanto você aproveita a vida? (questão 5)

- O quanto você consegue se concentrar? (questão 7)

- Em que medida você acha que sua vida tem sentido? (questão 6)

- Você é capaz de aceitar sua aparência física? (questão 11)

- Com que freqüência você tem sentimentos negativos tais como mau humor, desespero, ansiedade, depressão? (questão 26)

- Quão satisfeito (a) você esta consigo mesmo? (questão 19)

As questões que compõem o Domínio III (relações sociais) são:

- Quão satisfeito (a) você esta com suas relações pessoais (amigos, parentes, conhecidos, colegas)? (questão 20)

- Quão satisfeito (a) você está com sua vida sexual? (questão 21)

As questões que compõem o Domínio IV (meio ambiente) são:

- Quão seguro (a) você se sente em sua vida diária? (questão 8)

- Quão satisfeito (a) você esta com as condições do local onde você mora? (questão 23)

- Você tem dinheiro suficiente para satisfazer suas necessidades? (questão 12)

- Quão satisfeito (a) você esta com o seu acesso aos serviços de saúde? (questão 24)

- Quão disponíveis para você estão as informações que precisa no seu dia-a-dia? (questão 13)

- Em que medida você tem oportunidades de atividades de lazer? (questão 14)

- Quão saudável é o seu ambiente físico (clima, barulho, poluição, atrativos)? (questão 9)

- Quão satisfeito (a) você esta com o seu meio de transporte? (questão 25)

As questões sobre qualidade de vida geral e percepção geral da saúde são:

- Como você avaliaria sua qualidade de vida? (questão 1)

- Quão satisfeito (a) você esta com a sua saúde? (questão 2$)^{76}$.

A pontuação da escala de respostas pode variar de 1-5, no entanto algumas questões possuem o sistema de avaliação invertido 5-1, quais sejam: questão 3: em que medida você acha que sua dor (física) impede você de fazer o que você precisa? , questão 4: o quanto você precisa de algum tratamento médico para levar sua vida diária? e questão 26: com que freqüência você tem sentimentos negativos tais como mau humor, desespero, ansiedade, depressão? 
Quanto ao questionário semi-estruturado, este enriquece a pesquisa, pois contempla aspectos não avaliados nos instrumentos anteriores. As questões abordadas neste questionário foram:

A Sra. tem alguma crença ou religião?

A quanto tempo freqüenta a sra freqüenta esta religião?

Esta crença/religião possui alguma prática religiosa como: jejuar, orar, etc?

Com que freqüência você pratica?

Já mudou de religião alguma vez?

Depois que soube do problema da criança percebeu alguma alteração na freqüência desta prática religiosa?

A Sra. acredita em Deus?

O que é Deus para a Sra.?

A Sra. acredita que a sua crença/religião ajudou ou não a enfrentar o problema com o seu filho?

De que maneira?

Baseado na sua experiência de que a crença/religião ajudou você a enfrentar estes problemas, que mensagem ou sugestão você daria a outras mães que se encontram nesta situação?

\subsection{Procedimento}

Após a aprovação do projeto pelo Comitê de Ética em Pesquisa da Faculdade de Medicina da Universidade de São Paulo - Incor (Instituto do Coração), sob o número do protocolo CAPPesq n 0601/08, foi realizada a coleta de dados com as mães das crianças. A coleta foi feita pela autora do trabalho, durante a internação da criança e enquanto as mães aguardavam procedimento cirúrgico. Após a leitura do Termo de Consentimento Livre e Esclarecido, as mães responderam aos instrumentos.

As entrevistas foram realizadas em único dia.

O tempo de aplicação de cada instrumento foi de aproximadamente 10 minutos, assim levamos em média 30 minutos cada encontro. 
As entrevistas foram feitas junto ao leito da criança após a visita do médico e antes do horário de visitas dos pacientes, período em que as mães estão sozinhas.

\subsection{Instrumentos}

Após a assinatura do Termo de Consentimento Livre e Esclarecido (Anexo I) foram coletos os dados referentes as características sócio-demográficos (Anexo II).

$\mathrm{Na}$ sequencia, um questionário semi estruturado foi gravado em fita, com o objetivo de obter dados referentes à religiosidade/espiritualidade: existência, prática, frequiência e importância da mesma para o enfrentamento da situação (Anexo III).

E por fim, o WHOQOL-Breve (World Health Organization Quality of Life- versão abreviada), instrumento que avalia a qualidade de vida, composto por 24 questões e o instrumento CRE (Coping Religioso Espiritual) composto por 49 itens que avaliam aspectos relacionados à: religiosidade/espiritualidade.

\subsection{Análise dos Dados}

O objetivo do estudo foi avaliar se as mães das crianças com cardiopatia congênita utilizam a espiritualidade/religiosidade como estratégia de enfrentamento, e se utilizam de forma negativa ou positiva. Avaliar a qualidade de vida destas mães e suas possíveis associações com a estratégia de enfrentamento, também as variáveis: idade, estado civil, profissão, ter realizado cirurgia anterior, tempo de internação, saber sobre a data da cirurgia e grau de escolaridade. As variáveis categóricas são descritas em tabelas com frequências absolutas e relativas e as contínuas através de medidas de posição (mínimo e máximo), médias, desvios padrão e boxplots.

Para avaliação da consistência interna dos instrumentos avaliou-se o Alpha de Cronbach e para as correlações entre os Domínio dos questionários calculou-se o coeficiente de correlação de Pearson. As médias dos Domínios foram comparadas segundo os fatores das variáveis explicativas utilizando teste $t$-student ou Teste F de ANOVA (diferença entre 3 ou mais grupos). Especificamente para a comparação do Domínio 3 do escore de QV ajustou-se modelo de 
regressão linear com duas variáveis explicativas. O nível de significância dos testes foi de 5\%, sempre sob hipóteses bicaudais. 


\section{Resultados}

A amostra deste estudo foi composta por 48 mães de crianças com cardiopatia congênita, 22 $(45,8 \%)$ tiveram conhecimento do diagnóstico do filho até o primeiro anos de vida da criança, 38 $(79,2 \%)$ residentes no estado de São Paulo, metade (50\%) são casadas e as restantes se dividem em separadas, amasiadas, viúva ou solteira

Quanto ao grau de escolaridade apenas uma era analfabeta e as outras (98\%) possuíam o ensino fundamenta e/ou o ensino médio. Em relação a mãe analfabeta, a pesquisadora obteve o seu termo de consentimento para participação na pesquisa através de gravação. Como tanto os dados da mãe em questão quanto das outras foram coletados pela própria pesquisadora o grau de escolaridade não interferiu na coleta dos mesmos. Também participou da pesquisa uma única mãe com idade inferior a 18 anos, neste caso a obtenção do termo de consentimento foi feito pela mãe da participante e também pela mesma. Em relação a terem profissão ou trabalharem consideramos o fato de terem profissão e estarem trabalhando no momento da coleta dos dados para compilação dos mesmos. A maioria das mães $(52,1 \%)$ trabalhavam e $(47,9 \%)$ não trabalhavam embora algumas afirmaram ter profissão. Estes dados não foram considerados nesta pesquisa, no entanto, em futuras investigações devem ser avaliados uma vez que algumas mães afirmaram ter deixado de trabalhar para cuidar do filho em questão.

\subsection{Caracterização da amostra}

A amostra constituiu-se de 48 mães de crianças portadoras de cardiopatia congênita que estavam aguardando procedimento cirúrgico dos filhos internados na Unidade de Cardiopatia Congênita do Instituto do Coração. 


\subsubsection{Caracterização da amostra referente às crianças}

Em relação ao período de internação das crianças, 9 (18,7\%) haviam dado entrada no dia da coleta dos dados, 23 (48\%) estavam internadas no período de 1 a 7 dias, $15(31,2 \%)$ entre 8 e 15 dias e apenas $1(2,1 \%)$ acima de 15 dias.

A amostra foi aleatória em relação ao sexo das crianças, compreendendo 22 (45,8\%) meninos e $26(54,2 \%)$ meninas. A idade das crianças variou de 11 dias de nascido até 15 anos.

Vinte e nove $(60,4 \%)$ dessas crianças iriam ser submetidas à cirurgia pela primeira vez e 19 $(39,6 \%)$ crianças já haviam realizado algum procedimento cirúrgico anterior. Das crianças que já haviam realizado cirurgia, 16 (84,2\%) foram realizadas no Incor- Instituto do Coração.

A tabela abaixo resume as características das crianças estudadas.

Tabela 1 - Características da amostra relativa às crianças

\begin{tabular}{lcc}
\hline \multirow{2}{*}{ Variável } & \multicolumn{2}{c}{$\mathrm{N}=48$} \\
\cline { 2 - 3 } & $\mathrm{N}$ & $\%$ \\
\hline Sexo das crianças & 22 & 45,8 \\
Meninos & 26 & 54,2 \\
Meninas & & \\
\hline Tempo de internação das crianças & 9 & 18,7 \\
\hline dia & 23 & 48,0 \\
1 a 7 dias & 15 & 31,2 \\
8 a 15 dias & 1 & 2,1 \\
Mais de 15 dias & & \\
\hline Já realizou alguma cirurgia & 29 & 60,4 \\
Não & 19 & 39,6 \\
\hline Sim & & \\
\hline
\end{tabular}

\subsubsection{Caracterização da amostra referente às mães das crianças}

Foram consideradas as mães de crianças que iriam realizar o primeiro procedimento cirúrgico e também as mães de crianças que já tinham se submetido a cirurgias anteriores, mas que no momento da coleta aguardavam novo procedimento. 
Em relação à previsão da cirurgia, 19 mães $(39,6 \%)$ tinham conhecimento sobre a data qual seria realizada, enquanto $29(60,4 \%)$ não tinham informação alguma ou aguardavam algum resultado de exames.

Quanto ao estado civil 24 (50\%) são casadas, 11 (22,9\%) solteiras, $10(20,8 \%)$ moram com o companheiro ou se intitulam amasiadas, 1 (2,1\%) separada, 1 (2,1\%) viúva e $1(2,1 \%)$ divorciada.

Quanto a ter outros filhos $16(33,3 \%)$ mães tem apenas a criança em questão, 32 (66.7\%) tem outros filhos além da criança com cardiopatia congênita.

A idade mínima das mães é de 16 anos e a máxima idade é 56 anos, 24 mães (50\%) compreendem a faixa etária de 26 a 36 anos.

Quanto ao grau de escolaridade, 1 (2\%) mãe é analfabeta, 20 (41,7\%) possuem o ensino fundamental e $27(56,3 \%)$ o ensino médio.

Em relação à profissão, 25 mães $(52,1 \%)$ trabalham e 23 (47,9\%) não trabalham.

Quanto à descoberta do problema da criança, 5 mães $(10,4 \%)$ descobriram no pré-natal, 14 $(29,2 \%)$. Após nascimento da criança, $22(45,8 \%)$ até o primeiro ano de vida e $7(14,6 \%)$, durante a infância.

Quanto ao estado em que residem, 38 mães $(79,2 \%)$ moram no estado de São Paulo, sendo 17 no interior do estado, 4 (8,3\%) moram em Minas Gerais, 3 (6,2\%) no Rio de Janeiro, 1 (2,1\%) em Santa Catarina, 1 (2,1\%) no Estado do Ceará e 1 (2,1\%) no Estado da Bahia.

A tabela 2 resume as características das mães da amostra. 
Tabela 2 - Características da amostra relativa às mães das crianças

\begin{tabular}{|c|c|c|}
\hline \multirow{2}{*}{ Variável } & \multicolumn{2}{|c|}{$\mathrm{N}=48$} \\
\hline & $\mathrm{N}$ & $\%$ \\
\hline \multicolumn{3}{|c|}{ Conhecimento sobre a data da cirurgia } \\
\hline Tinham conhecimento & 19 & 39,6 \\
\hline Não tinham conhecimento & 29 & 60,4 \\
\hline \multicolumn{3}{|l|}{ Outros filhos } \\
\hline Não & 16 & 33,3 \\
\hline Sim & 32 & 66,7 \\
\hline \multicolumn{3}{|l|}{ Escolaridade de mãe } \\
\hline Analfabeta & 1 & 2,0 \\
\hline Ensino fundamental & 20 & 41,7 \\
\hline Ensino médio & 27 & 56,3 \\
\hline \multicolumn{3}{|l|}{ Profissão } \\
\hline Sim & 25 & 52,1 \\
\hline Não & 23 & 47,9 \\
\hline \multicolumn{3}{|l|}{ Quando soube do problema } \\
\hline Durante o pré natal & 5 & 10,4 \\
\hline No nascimento & 14 & 29,2 \\
\hline Até o primeiro ano de vida & 22 & 45,8 \\
\hline Após o primeiro ano de vida & 7 & 14,6 \\
\hline \multicolumn{3}{|l|}{ Estado de Procedência } \\
\hline São Paulo & 38 & 79,2 \\
\hline Minas Gerais & 4 & 8,3 \\
\hline Rio de Janeiro & 3 & 6,2 \\
\hline Santa Catarina & 1 & 2,1 \\
\hline Ceará & 1 & 2,1 \\
\hline Bahia & 1 & 2,1 \\
\hline
\end{tabular}

\subsection{Análise das características religiosas das mães}

Todas as mães afirmaram acreditar em Deus e apenas uma relatou não ter religião propriamente dita, mas, acredita que existe um Criador, ou força superior e possui a prática de orar sempre.

Quanto às religiões das mães, $25(52,1 \%)$ são Católicas, $16(33,3 \%)$ são Evangélicas, 1 $(2,1 \%)$ é Testemunha de Jeová, 1 (2,1\%) é Mórmon (considerada Igreja de Jesus Cristo do Santos 
do Últimos Dias), 3 (6,3\%) são Adventistas do Sétimo Dia, 1 (2,1\%) é Espírita Umbandista e 1 $(2,1 \%)$ não tem religião.

Todas as participantes afirmaram que estas religiões possuem algum tipo de prática religiosa, sendo que 15 mães (31,2\%) afirmaram realizar alguma dessas práticas diariamente, 15 mães $(31,2 \%)$ afirmaram realizar alguma prática as vezes (1 vez na semana), 8 (17\%) mães realizam freqüentemente ( 2 a 3 vezes na semana), 7 (14,5\%) nunca e $3(6,2 \%)$ raramente (1 vez no mês). Neste item o número de mães que possuem alguma prática religiosa foi de 41, pois embora todas afirmem que sua crença ou religião possuem alguma prática religiosa, 7 não praticam nunca. No entanto, a única mãe que afirmou não ter nenhuma religião propriamente dita declarou orar freqüentemente.

Quanto ao tempo que freqüentam a religião, 30 (63,8\%) freqüentam desde criança, 10 $(21,3 \%)$ a aproximadamente 10 anos e 7 (14,9\%) a menos de 5 anos, sendo que 17 (36,2\%) já mudaram de religião alguma vez e $30(63,8 \%)$ não.

Em relação à frequiência a alguma prática religiosa após o diagnóstico da criança, 35 $(72,9 \%)$ afirmaram que aumentaram a prática e que passaram a orar, freqüentar os cultos religiosos e buscar a Deus, 12 (25\%) disseram que não houve alteração, 1(2,1\%) afirmou que diminuiu e que atualmente deixou na mão de Deus.

A tabela 3 mostra uma síntese das características religiosas das mães. 
Tabela 3 - Caracterização Religiosa/Espiritual das mães das crianças com cardiopatia congênita

\begin{tabular}{|c|c|c|}
\hline \multirow{2}{*}{ Variável } & \multicolumn{2}{|c|}{$\mathrm{N}=48$} \\
\hline & $\mathrm{n}$ & $\%$ \\
\hline \multicolumn{3}{|l|}{ Religião } \\
\hline Católicas & 25 & 52,1 \\
\hline Evangélicas & 16 & 33,3 \\
\hline Testemunha de Jeová & 1 & 2,1 \\
\hline Mórmons & 1 & 2,1 \\
\hline Adventista & 3 & 6,3 \\
\hline Espírita umbandista & 1 & 2,1 \\
\hline Sem religião & 1 & 2,1 \\
\hline \multicolumn{3}{|l|}{ Freqüiência de prática religiosa: orar, etc. } \\
\hline Freqüentemente ( 2 a 3 vezes na semana) & 8 & 17 \\
\hline Nunca & 7 & 14,5 \\
\hline Às vezes (1 vez na semana) & 15 & 31,2 \\
\hline Raramente (1 vez no mês) & 3 & 6,3 \\
\hline Diariamente & 15 & 31,2 \\
\hline \multicolumn{3}{|l|}{ Tempo que freqüenta a religião* } \\
\hline Desde criança & 30 & 63,8 \\
\hline A mais de 10 anos & 10 & 21,3 \\
\hline 5 anos ou menos & 7 & 14,9 \\
\hline \multicolumn{3}{|l|}{ Já mudou de religião* } \\
\hline Sim & 17 & 36,2 \\
\hline Não & 30 & 63,8 \\
\hline \multicolumn{3}{|c|}{ Alterou a freq. na prática religiosa pós diagnóstico? } \\
\hline Sim, aumentou. & 35 & 72,9 \\
\hline Não & 12 & 25,0 \\
\hline Sim, diminuiu & 1 & 2,1 \\
\hline
\end{tabular}

3.3 Caracterização das Freqüências de respostas às questões abertas coletadas das mães

As questões: "O que é Deus para a sra.?”, "De que maneira a sra. acredita que a sua crença/religião ajudou ou não a enfrentar o problema com seu filho?" e "Baseado na sua experiência, de que a crença/religião ajudou você a enfrentar estes problemas, que mensagem ou sugestão você daria a outras mães que se encontram nesta situação?" estão descritas nas tabelas 4,5 e 6. 
3.3.1 Caracterização da frequiência de respostas a questão: "O que é Deus para a sra.?"

Através do agrupamento dos dados (Anexo VI), observa-se na Tabela 4 que em relação ao significado de Deus para estas mães, a palavra "Tudo" foi a mais citada, por 21 mães (44\%).

Tabela 4 - Freqüência das respostas da questão: "O que é Deus para a sra?"

\begin{tabular}{|c|c|c|}
\hline & \multicolumn{2}{|c|}{$\mathrm{N}=48$} \\
\hline & $\mathrm{n}$ & $\%$ \\
\hline \multicolumn{3}{|l|}{ O que é Deus } \\
\hline É tudo & 21 & 44,0 \\
\hline É tudo, seguida de breve explicação & 14 & 29,0 \\
\hline Outras respostas $*$ & 13 & 27,0 \\
\hline
\end{tabular}

* Mãe que afirmou não ter religião

3.3.2 Caracterização da frequiência de respostas a questão: "De que maneira a sra. acredita que a sua crença/religião ajudou ou não a enfrentar o problema com seu filho(a)?”

A Tabela 5 descreve de que forma essas mães acreditam que a sua crença/religião as ajudaram a enfrentar o problema com o filho. A resposta mais freqüente foi: "Dando força" ou "acalmando" 25 mães $(52,1 \%)$, através das orações também foi apontada como uma das maneiras de ajuda-las, 10 mães $(20,8 \%)$. As outras formas de ajuda citadas por 13 mães $(27,1 \%)$ apontam que de uma maneira ou de outra a crença/religião é considerada fonte de alívio, conforto, paz e suporte social (Anexo VII).

Tabela 5 - Freqüência das respostas da questão: "De que maneira a sra. acredita que a sua crença/religião ajudou ou não a enfrentar o problema com seu filho(a)?"

\begin{tabular}{|c|c|c|}
\hline & \multicolumn{2}{|c|}{$\mathrm{N}=48$} \\
\hline & $\mathrm{n}$ & $\%$ \\
\hline \multicolumn{3}{|l|}{ De que maneira? } \\
\hline Dando força/acalmando * & 25 & 52,1 \\
\hline Através da orações & 10 & 20,8 \\
\hline Outras respostas & 13 & 27,1 \\
\hline
\end{tabular}

* Mãe que afirmou não ter religião 
3.3.3 Caracterização da frequiência de respostas a questão: "Baseado na sua experiência de que a crença/religião ajudou você a enfrentar estes problemas, que mensagem ou sugestão você daria a outras mães que se encontram nesta situação?"

Em relação às sugestões para outras mães, que também se encontram na mesma situação, 36 mães (75\%) responderam "Buscar Deus”, "Pedir a Deus”, “Acreditar em Deus", 7 mães (14,6\%) sugerem a outras mães terem fé e 5 mães (10,4\%) deram outras sugestões (Anexo VIII).

Tabela 6 - Freqüência das respostas da questão: "Baseado na sua experiência de que a crença/religião ajudou você a enfrentar estes problemas, que mensagem ou sugestão você daria a outras mães que se encontram nesta situação?"

\begin{tabular}{|c|c|c|}
\hline & \multicolumn{2}{|c|}{$\mathrm{N}=48$} \\
\hline & $\mathrm{n}$ & $\%$ \\
\hline \multicolumn{3}{|c|}{ Sugestões a outras mães } \\
\hline Buscarem à Deus & 36 & 75 \\
\hline Terem fé & 7 & 14,6 \\
\hline Outras sugestões * & 5 & 10,4 \\
\hline
\end{tabular}

* Mãe que afirmou não ter religião

3.4 - Análise de fidedignidade do instrumento WHOQOL-Breve na amostra

Para analisarmos a fidedignidade do teste na amostra, foi aplicado o Alpha de Cronbach para todos os domínios que compõem o WHOQOL-Bref (Tabela 7). Todos os domínios apresentaram um resultado acima de 0,5 que é considerado aceitável para uma amostra de 48 mães ${ }^{77}$. Assim sendo, os domínios deste instrumento apresenta consistência interna satisfatória. 
Tabela 7 - Análise de Alpha de Cronbach nos domínios no WHOQOL - Breve

\begin{tabular}{|c|c|}
\hline Domínios & Alpha de Cronbach \\
\hline Físico & 0,738 \\
\hline Psicológico & 0,718 \\
\hline Relações Sociais & 0,655 \\
\hline Meio Ambiente & 0,759 \\
\hline Total & 0,852 \\
\hline
\end{tabular}

3.5 - Análise dos dados obtidos pelo Instrumento WHOQOL - Breve

Entre os quatro domínios que compõem o instrumento: físico, psicológico, relações social e meio ambiente (Tabela 8), o que obteve maior média foi o das relações sociais $16,11(\mathrm{dp}=3,43)$, seguido do domínio físico 15,40 ( $\mathrm{dp}=2,66)$, psicológico 14,86 ( $\mathrm{dp}=2,51)$ e meio ambiente 13,69 $(\mathrm{dp}=2,56)$.

Tabela 8 - Distribuição das médias entre os domínios do WHOQOL - Breve na amostra

\begin{tabular}{|c|c|c|c|c|c|c|c|}
\hline \multirow{2}{*}{ Domínios } & \multirow{2}{*}{$\mathrm{N}$} & \multirow{2}{*}{ Mínimo } & \multirow{2}{*}{ Máximo } & \multirow{2}{*}{ Média } & \multirow{2}{*}{ Desvio padrão } & \multicolumn{2}{|c|}{ IC para média $(95 \%)$} \\
\hline & & & & & & Inf & Sup \\
\hline Físico & 48 & 9,1 & 20,0 & 15,40 & 2,66 & 14,63 & 16,18 \\
\hline Psicológico & 48 & 6,7 & 20,0 & 14,86 & 2,51 & 14,13 & 15,59 \\
\hline \multicolumn{8}{|l|}{ Relações } \\
\hline Sociais & 48 & 4,0 & 20,0 & 16,11 & 3,43 & 15,11 & 17,11 \\
\hline \multicolumn{8}{|l|}{ Meio } \\
\hline Ambiente & 48 & 7,0 & 18,5 & 13,69 & 2,56 & 12,94 & 14,43 \\
\hline \multicolumn{8}{|l|}{$\begin{array}{l}\text { Auto- } \\
\text { avaliação da }\end{array}$} \\
\hline QV & 48 & 4,0 & 20,0 & 15,29 & 2,69 & 14,51 & 16,07 \\
\hline
\end{tabular}

Comparando as três questões: Q20: "Quão satisfeito(a) você esta com suas relações pessoais (amigos, parentes, conhecidos, colegas)?”, Q21: “Quão satisfeito(a) você esta com sua vida sexual? e Q22: “Quão satisfeito(a) você esta com o apoio que você recebe de seus amigos?, 
que compõem o domínio relações sociais a questão 22, foi que obteve a média mais alta (56,2\%) (Tabela 9).

Dados gerais sobre a saúde e a qualidade de vida das mães de crianças com cardiopatia congênita podem ser encontrados nas questões: Q1: "Como você avaliaria sua qualidade de vida?” e Q2: "Quão satisfeito(a) você esta com sua saúde?) do instrumento WHOQOL-bref. Através da análise das respostas (Tabela 9) podemos observar que na questão que avalia a sua percepção quanto à qualidade de vida $(\mathrm{Q} 1), 10$ mães $(20,8 \%)$ consideram muito boa, 25 mães $(52,1 \%)$ consideram boa, $12(25 \%)$ nem ruim, nem boa, $0(0 \%)$ consideram ruins e $1(2,1 \%)$ considera muito ruim. No entanto podemos avaliar que mais da metade das mães $35(72,9 \%)$ consideram sua qualidade de vida como sendo boa ou muito boa.

Quanto à questão que avalia a percepção sobre o quão satisfeitas elas estão com a sua saúde (Q2), 9 mães $(18,8 \%)$ consideram muito satisfeita, 22 mães $(45,8 \%)$ consideram satisfeitas, 14 (29.2\%) nem satisfeita, nem insatisfeita, 2 (4,2\%) insatisfeita e $1(2 \%)$ muito insatisfeita. Assim sendo 31 mães $(64,6 \%)$ tem percepção em relação a saúde satisfatória.

Dados específicos sobre quanto à saúde e a qualidade de vida dessas mães podem ser descritos através da análise de freqüência de respostas das Q4: "O quanto você precisa de algum tratamento médico para levar sua vida diária?, Q16: "Quão satisfeito(a) você esta com o seu sono?" e através da questão 26: "Com que freqüência você tem sentimentos negativos tais como: mau humor, desespero, ansiedade, depressão?”, 27 mães declararam não precisar de nada $(56,2 \%)$ e 12 muito pouco $(25 \%)$ tratamento médico para levar a sua vida diária. Em relação a satisfação com o sono, 6 mães declararam muito insatisfeitas (12,5\%), 11 insatisfeitas (22,9\%), 12 mães nem satisfeitas, nem insatisfeitas (25\%), 12 mães satisfeitas (25\%) e 7 muito satisfeitas (14,6\%). A questão que obteve a maior média foi a Q26: 29 mães declararam apresentar frequentemente $(60,4 \%)$ algum tipo de sentimentos negativos tais como: mau humor, desespero, ansiedade e depressão (Tabela 9). 
Tabela 9 - Distribuição das freqüências das questões de QV nos domínios

\section{Questões que compõem o Domínio 1 (físico)}

\begin{tabular}{|c|c|c|c|c|c|c|c|}
\hline Item & & 1 & 2 & 3 & 4 & 5 & Total \\
\hline Q3 inv * & & nada & $\begin{array}{l}\text { muito } \\
\text { pouco }\end{array}$ & $\begin{array}{l}\text { mais ou } \\
\text { menos }\end{array}$ & bastante & Extremamente & \\
\hline \multirow{2}{*}{$\begin{array}{l}\text { Em que medida você } \\
\text { acha que sua dor } \\
\text { (física) impede você de } \\
\text { fazer o que você } \\
\text { precisa? }\end{array}$} & $\mathrm{N}$ & 27 & 12 & 6 & 2 & 1 & 48 \\
\hline & $\%$ & 56,2 & 25 & 12,5 & 4,2 & 2,1 & 100 \\
\hline Item & & 1 & 2 & 3 & 4 & 5 & Total \\
\hline Q4 inv * & & nada & $\begin{array}{l}\text { muito } \\
\text { pouco }\end{array}$ & $\begin{array}{l}\text { mais ou } \\
\text { menos }\end{array}$ & bastante & Extremamente & \\
\hline \multirow{2}{*}{$\begin{array}{l}\text { O quanto você precisa } \\
\text { de algum tratamento } \\
\text { médico para levar sua } \\
\text { vida diária? }\end{array}$} & $\mathrm{N}$ & 27 & 12 & 6 & 2 & 1 & 48 \\
\hline & $\%$ & 56,2 & 25 & 12,5 & 4,2 & 2,1 & 100 \\
\hline Item & & 1 & 2 & 3 & 4 & 5 & Total \\
\hline Q10 & & nada & $\begin{array}{l}\text { muito } \\
\text { pouco }\end{array}$ & médio & muito & Completamente & \\
\hline \multirow{2}{*}{$\begin{array}{l}\text { Você tem energia } \\
\text { suficiente para seu dia- } \\
\text { a-dia? }\end{array}$} & $\mathrm{N}$ & 0 & 4 & 14 & 16 & 14 & 48 \\
\hline & $\%$ & 0 & 8,3 & 29,2 & 33,3 & 29,2 & 100 \\
\hline Item & & 1 & 2 & 3 & 4 & 5 & Total \\
\hline Q15 & & muito ruim & ruim & $\begin{array}{l}\text { nem ruim } \\
\text { nem bom }\end{array}$ & Bom & muito bom & \\
\hline \multirow{2}{*}{$\begin{array}{l}\text { Quão bem você é capaz } \\
\text { de se locomover? }\end{array}$} & $\mathrm{N}$ & 2 & 1 & 5 & 14 & 26 & 48 \\
\hline & $\%$ & 4,1 & 2,1 & 10,4 & 29,2 & 54,2 & 100 \\
\hline Item & & 1 & 2 & 3 & 4 & 5 & Total \\
\hline Q16 & & $\begin{array}{l}\text { muito } \\
\text { insatisfeito }\end{array}$ & insatisfeito & $\begin{array}{l}\text { nem } \\
\text { satisfeito } \\
\text { nem } \\
\text { insatisfeito }\end{array}$ & satisfeito & muito satisfeito & \\
\hline \multirow{2}{*}{$\begin{array}{l}\text { Quão satisfeito(a) você } \\
\text { esta com o seu sono? }\end{array}$} & $\mathrm{N}$ & 6 & 11 & 12 & 12 & 7 & 48 \\
\hline & $\%$ & 12,5 & 22,9 & 25 & 25 & 14,6 & 100 \\
\hline
\end{tabular}




\begin{tabular}{|c|c|c|c|c|c|c|c|}
\hline Item & & 1 & 2 & 3 & 4 & 5 & Total \\
\hline Q17 & & $\begin{array}{l}\text { muito } \\
\text { insatisfeito }\end{array}$ & insatisfeito & $\begin{array}{l}\text { nem } \\
\text { satisfeito } \\
\text { nem } \\
\text { insatisfeito }\end{array}$ & satisfeito & muito satisfeito & \\
\hline \multirow{2}{*}{$\begin{array}{l}\text { Quão satisfeito(a) você } \\
\text { esta com sua } \\
\text { capacidade de } \\
\text { desempenhar as } \\
\text { atividades do seu dia-a- } \\
\text { dia? }\end{array}$} & $\overline{\mathrm{N}}$ & 3 & 4 & 10 & 22 & 9 & 48 \\
\hline & $\%$ & 6,3 & 8,3 & 20,8 & 45,8 & 18,8 & 100 \\
\hline Item & & 1 & 2 & 3 & 4 & 5 & Total \\
\hline Q18 & & $\begin{array}{l}\text { muito } \\
\text { insatisfeito }\end{array}$ & insatisfeito & $\begin{array}{l}\text { nem } \\
\text { satisfeito } \\
\text { nem } \\
\text { insatisfeito }\end{array}$ & satisfeito & muito satisfeito & \\
\hline \multirow{2}{*}{$\begin{array}{l}\text { Quão satisfeito(a) você } \\
\text { esta com sua } \\
\text { capacidade para o } \\
\text { trabalho? }\end{array}$} & $\mathrm{N}$ & 4 & 4 & 8 & 24 & 8 & 48 \\
\hline & $\%$ & 8,3 & 8,3 & 16,7 & 50 & 16,7 & 100 \\
\hline
\end{tabular}

Questões que compõem o Domínio 2 (psicológico)

\begin{tabular}{|c|c|c|c|c|c|c|c|}
\hline Item & & 1 & 2 & 3 & 4 & 5 & Total \\
\hline Q5 & & nada & $\begin{array}{l}\text { muito } \\
\text { pouco }\end{array}$ & $\begin{array}{l}\text { mais ou } \\
\text { menos }\end{array}$ & bastante & Extremamente & \\
\hline \multirow{2}{*}{$\begin{array}{l}\text { O quanto você } \\
\text { aproveita a vida? }\end{array}$} & $\mathrm{N}$ & 2 & 5 & 11 & 18 & 12 & 48 \\
\hline & $\%$ & 4,2 & 10,4 & 22,9 & 37,5 & 25 & 100 \\
\hline Item & & 1 & 2 & 3 & 4 & 5 & Total \\
\hline Q6 & & nada & $\begin{array}{l}\text { muito } \\
\text { pouco }\end{array}$ & $\begin{array}{l}\text { mais ou } \\
\text { menos }\end{array}$ & bastante & Extremamente & \\
\hline \multirow{2}{*}{$\begin{array}{l}\text { Em que medida você } \\
\text { acha que a sua vida } \\
\text { tem sentido? }\end{array}$} & $\mathrm{N}$ & 0 & 2 & 4 & 23 & 19 & 48 \\
\hline & $\%$ & 0 & 4,2 & 8,3 & 47,9 & 39,6 & 100 \\
\hline
\end{tabular}




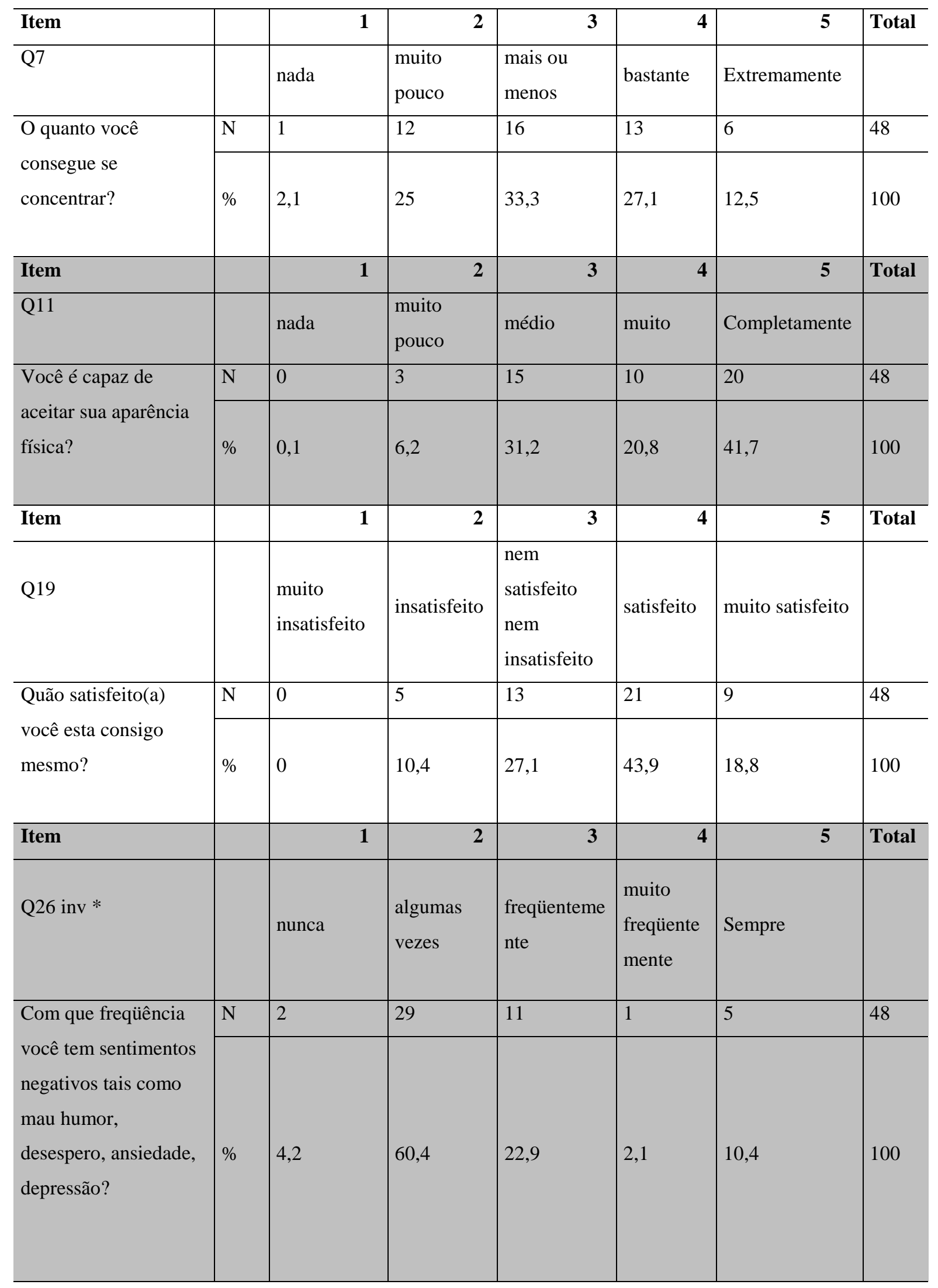


Questões que compõem o Domínio 3 (relações sociais)

\begin{tabular}{|c|c|c|c|c|c|c|c|}
\hline Item & & $\mathbf{1}$ & 2 & 3 & 4 & 5 & Total \\
\hline Q20 & & $\begin{array}{l}\text { muito } \\
\text { insatisfeito }\end{array}$ & insatisfeito & $\begin{array}{l}\text { nem } \\
\text { satisfeito } \\
\text { nem } \\
\text { insatisfeito }\end{array}$ & satisfeito & muito satisfeito & \\
\hline \multirow{2}{*}{$\begin{array}{l}\text { Quão satisfeito(a) } \\
\text { você esta com suas } \\
\text { relações pessoais } \\
\text { (amigos, parentes, } \\
\text { conhecidos, colegas)? }\end{array}$} & $\mathrm{N}$ & 2 & 3 & 4 & 19 & 20 & 48 \\
\hline & $\%$ & 4,2 & 6,2 & 8,3 & 39,6 & 41,7 & 100 \\
\hline Item & & 1 & 2 & 3 & 4 & 5 & Total \\
\hline Q21 & & $\begin{array}{l}\text { muito } \\
\text { insatisfeito }\end{array}$ & insatisfeito & $\begin{array}{l}\text { nem } \\
\text { satisfeito } \\
\text { nem } \\
\text { insatisfeito }\end{array}$ & satisfeito & muito satisfeito & \\
\hline \multirow{2}{*}{$\begin{array}{l}\text { Quão satisfeito(a) } \\
\text { você esta com sua } \\
\text { vida sexual? }\end{array}$} & $\mathrm{N}$ & 5 & 3 & 13 & 10 & 17 & 48 \\
\hline & $\%$ & 10,5 & 6,2 & 27,1 & 20,8 & 35,4 & 100 \\
\hline Item & & 1 & 2 & 3 & 4 & 5 & Total \\
\hline Q22 & & $\begin{array}{l}\text { muito } \\
\text { insatisfeito }\end{array}$ & insatisfeito & $\begin{array}{l}\text { nem } \\
\text { satisfeito } \\
\text { nem } \\
\text { insatisfeito }\end{array}$ & satisfeito & $\begin{array}{l}\text { Muito } \\
\text { insatisfeito }\end{array}$ & \\
\hline \multirow{2}{*}{$\begin{array}{l}\text { Quão satisfeito(a) } \\
\text { você esta com o apoio } \\
\text { que você recebe de } \\
\text { seus amigos? }\end{array}$} & $\mathrm{N}$ & 1 & 2 & 3 & 15 & 27 & 48 \\
\hline & $\%$ & 2,2 & 4,2 & 6,2 & 31,2 & 56,2 & 100 \\
\hline
\end{tabular}

Questões que compõem o Domínio 4 (meio ambiente)

\begin{tabular}{|c|c|c|c|c|c|c|c|}
\hline Item & & 1 & 2 & 3 & 4 & 5 & Total \\
\hline Q8 & & nada & $\begin{array}{l}\text { muito } \\
\text { pouco }\end{array}$ & $\begin{array}{l}\text { mais ou } \\
\text { menos }\end{array}$ & bastante & Extremamente & \\
\hline \multirow{2}{*}{$\begin{array}{l}\text { Quão seguro(a) você } \\
\text { se sente em sua vida } \\
\text { diária? }\end{array}$} & $\mathrm{N}$ & 1 & 2 & 15 & 26 & 4 & 48 \\
\hline & $\%$ & 2,1 & 4,2 & 31,2 & 54,2 & 8,3 & 100 \\
\hline
\end{tabular}




\begin{tabular}{|c|c|c|c|c|c|c|c|}
\hline Item & & 1 & 2 & 3 & 4 & 5 & Total \\
\hline Q9 & & nada & $\begin{array}{l}\text { muito } \\
\text { pouco }\end{array}$ & $\begin{array}{l}\text { mais ou } \\
\text { menos }\end{array}$ & bastante & Extremamente & \\
\hline \multirow{2}{*}{$\begin{array}{l}\text { Quão saudável é o seu } \\
\text { ambiente físico (clima, } \\
\text { barulho, poluição, } \\
\text { atrativos)? }\end{array}$} & $\mathrm{N}$ & 2 & 4 & 13 & 24 & 5 & 48 \\
\hline & $\%$ & 4,2 & 8,3 & 27,1 & 50 & 10,4 & 100 \\
\hline Item & & 1 & 2 & 3 & 4 & 5 & Total \\
\hline Q12 & & nada & $\begin{array}{l}\text { muito } \\
\text { pouco }\end{array}$ & médio & muito & Completamente & \\
\hline \multirow{2}{*}{$\begin{array}{l}\text { Você tem dinheiro } \\
\text { suficiente para } \\
\text { satisfazer suas } \\
\text { necessidades? }\end{array}$} & $\mathrm{N}$ & 4 & 12 & 26 & 4 & 2 & 48 \\
\hline & $\%$ & 8,3 & 25 & 54,2 & 8,3 & 4,2 & 100 \\
\hline Item & & 1 & 2 & 3 & 4 & 5 & Total \\
\hline Q13 & & nada & $\begin{array}{l}\text { muito } \\
\text { pouco }\end{array}$ & médio & muito & Completamente & \\
\hline \multirow{2}{*}{$\begin{array}{l}\text { Quão disponíveis para } \\
\text { você estão as } \\
\text { informações que } \\
\text { precisa no seu dia-a- } \\
\text { dia? }\end{array}$} & $\mathrm{N}$ & 1 & 5 & 14 & 19 & 9 & 48 \\
\hline & $\%$ & 2 & 10,4 & 29,2 & 39,6 & 18,8 & 100 \\
\hline Item & & 1 & 2 & 3 & 4 & 5 & Total \\
\hline Q14 & & nada & $\begin{array}{l}\text { muito } \\
\text { pouco }\end{array}$ & médio & muito & Completamente & \\
\hline \multirow{2}{*}{$\begin{array}{l}\text { Em que medida você } \\
\text { tem oportunidades de } \\
\text { atividade de lazer? }\end{array}$} & $\mathrm{N}$ & 9 & 11 & 17 & 8 & 3 & 48 \\
\hline & $\%$ & 18,8 & 22,9 & 35,4 & 16,7 & 6,2 & 100 \\
\hline Item & & 1 & 2 & 3 & 4 & 5 & Total \\
\hline Q23 & & $\begin{array}{l}\text { muito } \\
\text { insatisfeito }\end{array}$ & insatisfeito & $\begin{array}{l}\text { nem } \\
\text { satisfeito } \\
\text { nem } \\
\text { insatisfeito }\end{array}$ & satisfeito & muito satisfeito & \\
\hline \multirow{2}{*}{$\begin{array}{l}\text { Quão satisfeito(a) } \\
\text { você esta com as } \\
\text { condições do local } \\
\text { onde mora? }\end{array}$} & $\mathrm{N}$ & 5 & 4 & 6 & 15 & 18 & 48 \\
\hline & $\%$ & 10,5 & 8,3 & 12,5 & 31,2 & 37,5 & 100 \\
\hline
\end{tabular}




\begin{tabular}{|c|c|c|c|c|c|c|c|}
\hline Item & & 1 & 2 & 3 & 4 & 5 & Total \\
\hline Q24 & & \begin{tabular}{|l} 
muito \\
insatisfeito
\end{tabular} & insatisfeito & $\begin{array}{l}\text { nem } \\
\text { satisfeito } \\
\text { nem } \\
\text { insatisfeito }\end{array}$ & satisfeito & muito satisfeito & \\
\hline \multirow{2}{*}{$\begin{array}{l}\text { Quão satisfeito(a) } \\
\text { você esta com o seu } \\
\text { acesso aos serviços de } \\
\text { saúde? }\end{array}$} & $\mathrm{N}$ & 2 & 2 & 8 & 20 & 16 & 48 \\
\hline & $\%$ & 4,1 & 4,2 & 16,7 & 41,7 & 33,3 & 100 \\
\hline Item & & 1 & 2 & 3 & 4 & 5 & Total \\
\hline Q25 & & $\begin{array}{l}\text { muito } \\
\text { insatisfeito }\end{array}$ & insatisfeito & $\begin{array}{l}\text { nem } \\
\text { satisfeito } \\
\text { nem } \\
\text { insatisfeito }\end{array}$ & satisfeito & muito satisfeito & \\
\hline \multirow{2}{*}{$\begin{array}{l}\text { Quão satisfeito(a) } \\
\text { você esta com o seu } \\
\text { meio de transporte? }\end{array}$} & $\mathrm{N}$ & 4 & 6 & 13 & 16 & 9 & 48 \\
\hline & $\%$ & 8,3 & 12,5 & 27,1 & 33,3 & 18,8 & 100 \\
\hline
\end{tabular}

Questões gerais relativas à QV

\begin{tabular}{|c|c|c|c|c|c|c|c|}
\hline Item & & 1 & 2 & 3 & 4 & 5 & Total \\
\hline Q1 & & muito ruim & ruim & $\begin{array}{l}\text { nem ruim } \\
\text { nem boa }\end{array}$ & Boa & muito boa & \\
\hline \multirow{2}{*}{$\begin{array}{l}\text { Como você avaliaria } \\
\text { sua qualidade de vida? }\end{array}$} & $\mathrm{N}$ & 1 & 0 & 12 & 25 & 10 & 48 \\
\hline & $\%$ & 2,1 & 0 & 25 & 52,1 & 20,8 & 100 \\
\hline Item & & 1 & 2 & 3 & 4 & 5 & Total \\
\hline Q2 & & $\begin{array}{l}\text { muito } \\
\text { insatisfeito }\end{array}$ & insatisfeito & $\begin{array}{l}\text { nem } \\
\text { satisfeito } \\
\text { nem } \\
\text { insatisfeito }\end{array}$ & satisfeito & muito satisfeito & \\
\hline \multirow{2}{*}{$\begin{array}{l}\text { Quão satisfeito(a) } \\
\text { você esta com a sua } \\
\text { saúde? }\end{array}$} & $\mathrm{N}$ & 1 & 2 & 14 & 22 & 9 & 48 \\
\hline & $\%$ & 2 & 4,2 & 29,2 & 45,8 & 18,8 & 100 \\
\hline
\end{tabular}

* Itens com sistema de pontuação inversa 
Em relação à freqüência dos escores (Gráfico 1), o domínio Relações Sociais foi o que obteve a maior freqüência de respostas com escores altos, seguido do domínio físico, psicológico e meio ambiente. Em relação à auto-avaliação apenas uma mãe não considerou sua qualidade de vida boa.

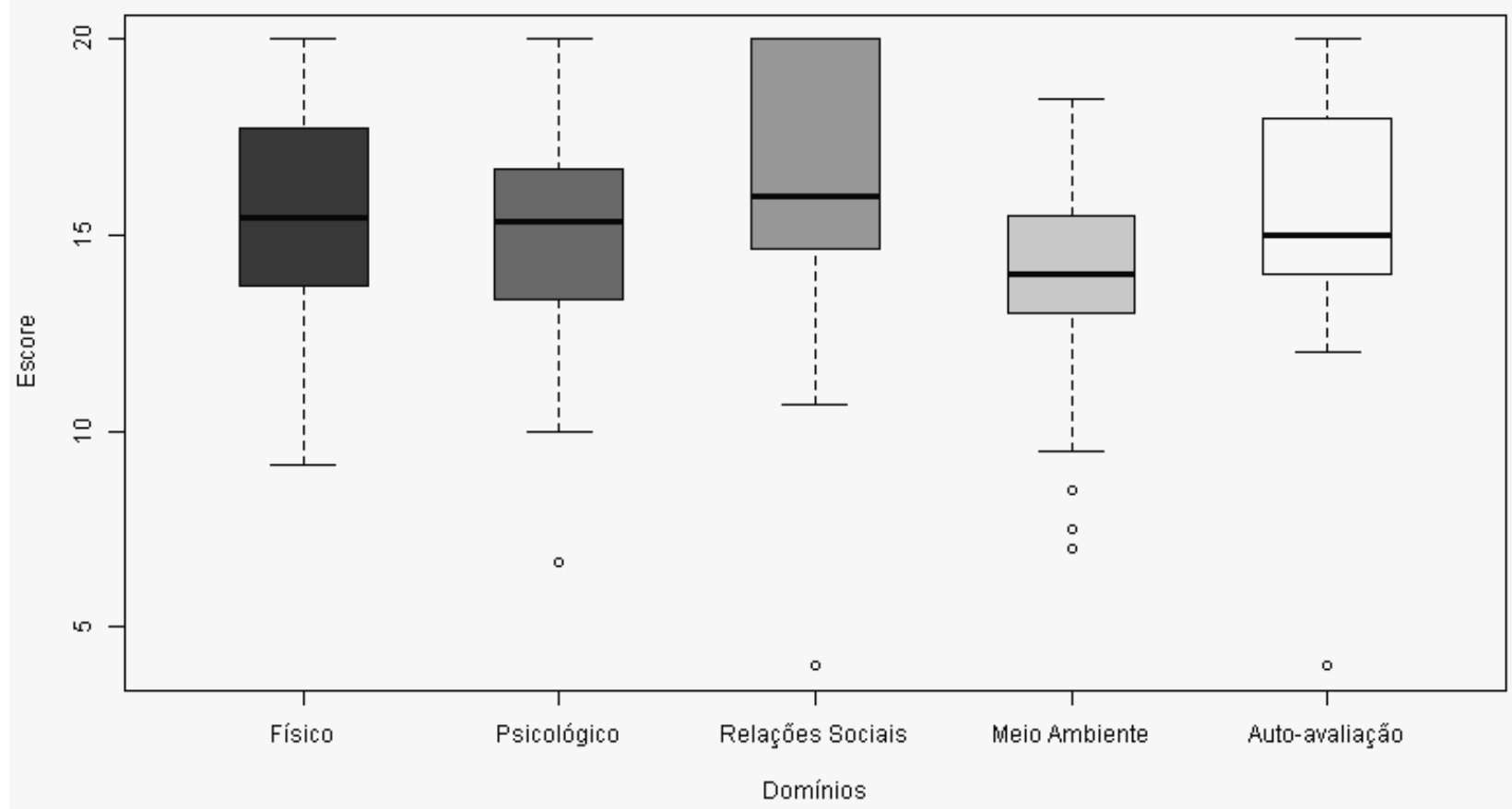

Gráfico 1 - Frequiência dos Escores x Domínios do WHOQOL - Breve

3.6 Análise de fidedignidade do instrumento CRE - Coping Religioso Espiritual na amostra

A avaliação da consistência interna do instrumento CRE pelo Alpha de Cronbach demonstrou alta fidedignidade em todos os fatores positivos. Nos fatores negativos o único que não apresentou coeficiente interno satisfatório foi o fator N4 (Insatisfação com o outro institucional), ou seja, as questões que compõe o fator não satisfazem a suposição de correlação entre os itens para essa amostra. 
Tabela 10 - Análise de Alpha de Cronbach no CRE - Breve

\begin{tabular}{ll}
\hline \multicolumn{1}{c}{ Fatores } & Alpha de \\
& Cronbach \\
\hline P1 - Transformação de sua vida & 0,751 \\
P2 - Busca de ajuda espiritual & 0,792 \\
P3 - Oferta de ajuda a outro & 0,803 \\
P4 - Posição positiva frente a Deus & 0,662 \\
P5 - Busca pessoal de crescimento espiritual & 0,636 \\
P6 - Ações em busca do outro institucional & 0,663 \\
P7 - Busca pessoal de conhecimento espiritual & 0,722 \\
\hline \multicolumn{1}{c}{ Escore Positivo Total } & 0,912 \\
\hline N1 - Reavaliação negativa de Deus & 0,579 \\
N2 - Posição negativo frente a Deus & 0,621 \\
N3 - Reavaliação negativa do significado & 0,706 \\
N4 - Insatisfação com o outro institucional & 0,186 \\
\hline \multicolumn{1}{c}{ Escore Negativo Total } & 0,643 \\
\hline
\end{tabular}

3.7 Análise dos dados obtidos pelo Instrumento CRE - Coping Religioso Espiritual

Quanto à questão que pede a descrição da situação que a mãe viveu de maior estresse nos últimos três anos (Anexo IX), 31 mães (64,6\%) descreveram situações relacionadas à criança:

As outras 17 mães $(35,4 \%)$ relataram situações que não estavam relacionadas à doença da criança ou a situação que vivenciavam no momento (Tabela 11).

Tabela 11 - Freqüência das respostas à questão que pede a descrição da situação que a mãe viveu de maior estresse nos últimos três anos

\begin{tabular}{lrr}
\hline & \multicolumn{2}{c}{$\mathrm{N}=48$} \\
\cline { 2 - 3 } & $\mathrm{n}$ & $\%$ \\
\hline Situação de maior estresse nos últimos 3 anos & & \\
\hline Estresse gerado pelo diagnóstico & 13 & 27,0 \\
Angústia e medo da cirurgia & 10 & 20,8 \\
Piora da saúde da criança & 2 & 4,2 \\
Permanência da criança na UTI & 1 & 2,1 \\
Espera pelo transplante & 1 & 2,1 \\
A internação & 2 & 4,2 \\
A parada cardíaca do filho que vivenciou & 2 & 4,2 \\
Não relacionadas a criança ou situação atual & 17 & 35,4 \\
\hline
\end{tabular}


3.7.1 Análise dos fatores positivos e negativos que compõem o instrumento CRE - Coping Religioso Espiritual

Em relação à média dos fatores positivos e negativos que compõem o Instrumento CRE, o que obteve maior média no fator positivo foi a P4- Posição positiva frente a Deus $(4,71)$ e no fator negativo a N2- Posicionamento negativo frente a Deus (2,51) (Tabela 12 e gráfico 2).

Tabela 12 - Distribuição das médias entre os Fatores Positivos e Negativos do CRE - Breve

\begin{tabular}{|c|c|c|c|c|c|c|c|}
\hline \multirow[t]{2}{*}{ Fatores } & \multirow[t]{2}{*}{$\mathrm{N}$} & \multirow[t]{2}{*}{ Mínimo } & \multirow[t]{2}{*}{ Máximo } & \multirow[t]{2}{*}{ Média } & \multirow{2}{*}{$\begin{array}{l}\text { Desvio } \\
\text { padrão }\end{array}$} & \multicolumn{2}{|c|}{$\begin{array}{l}\text { IC para média } \\
(95 \%)\end{array}$} \\
\hline & & & & & & Inf & Sup \\
\hline P1 - Transformação de & & & & & & & \\
\hline si e/ou de sua vida & 48 & 1,56 & 4,67 & 3,54 & 0,72 & 3,33 & 3,75 \\
\hline P2 -Ações em busca de & & & & & & & \\
\hline ajuda espiritual & 48 & 1,00 & 5,00 & 2,88 & 1,09 & 2,57 & 3,20 \\
\hline P3 - Oferta de ajuda a & & & & & & & \\
\hline outro & 48 & 1,20 & 5,00 & 3,08 & 0,99 & 2,79 & 3,37 \\
\hline P4 - Posicionamento & & & & & & & \\
\hline positivo frente a Deus & 48 & 3,20 & 5,00 & 4,71 & 0,43 & 4,58 & 4,83 \\
\hline $\begin{array}{l}\text { P5 - Busca pessoal de } \\
\text { crescimento espiritual }\end{array}$ & 48 & 1,25 & 5,00 & 3,17 & 0,96 & 2,89 & 3,45 \\
\hline $\begin{array}{l}\text { P6 - Ações em busca do } \\
\text { outro institucional }\end{array}$ & 48 & 2,33 & 5,00 & 3,95 & 0,84 & 3,71 & 4,19 \\
\hline $\begin{array}{l}\text { P7 - Busca pessoal de } \\
\text { conhecimento espiritual }\end{array}$ & 48 & 1,00 & 4,67 & 2,81 & 1,08 & 2,50 & 3,13 \\
\hline $\begin{array}{l}\text { N1 - Reavaliação } \\
\text { negativa de Deus }\end{array}$ & 48 & 1,00 & 3,60 & 1,53 & 0,60 & 1,36 & 1,70 \\
\hline $\begin{array}{l}\text { N2 - Posicionamento } \\
\text { negativo frente a Deus }\end{array}$ & 48 & 1,00 & 5,00 & 2,51 & 1,14 & 2,18 & 2,84 \\
\hline $\begin{array}{l}\text { N3 - Reavaliação } \\
\text { negativa do significado }\end{array}$ & 48 & 1,00 & 5,00 & $\mathbf{1 , 5 8}$ & 0,85 & 1,34 & 1,83 \\
\hline $\begin{array}{l}\text { N4 - Insatisfação com o } \\
\text { outro institucional }\end{array}$ & 48 & 1,00 & 3,67 & 2,02 & 0,74 & 1,81 & 2,24 \\
\hline
\end{tabular}




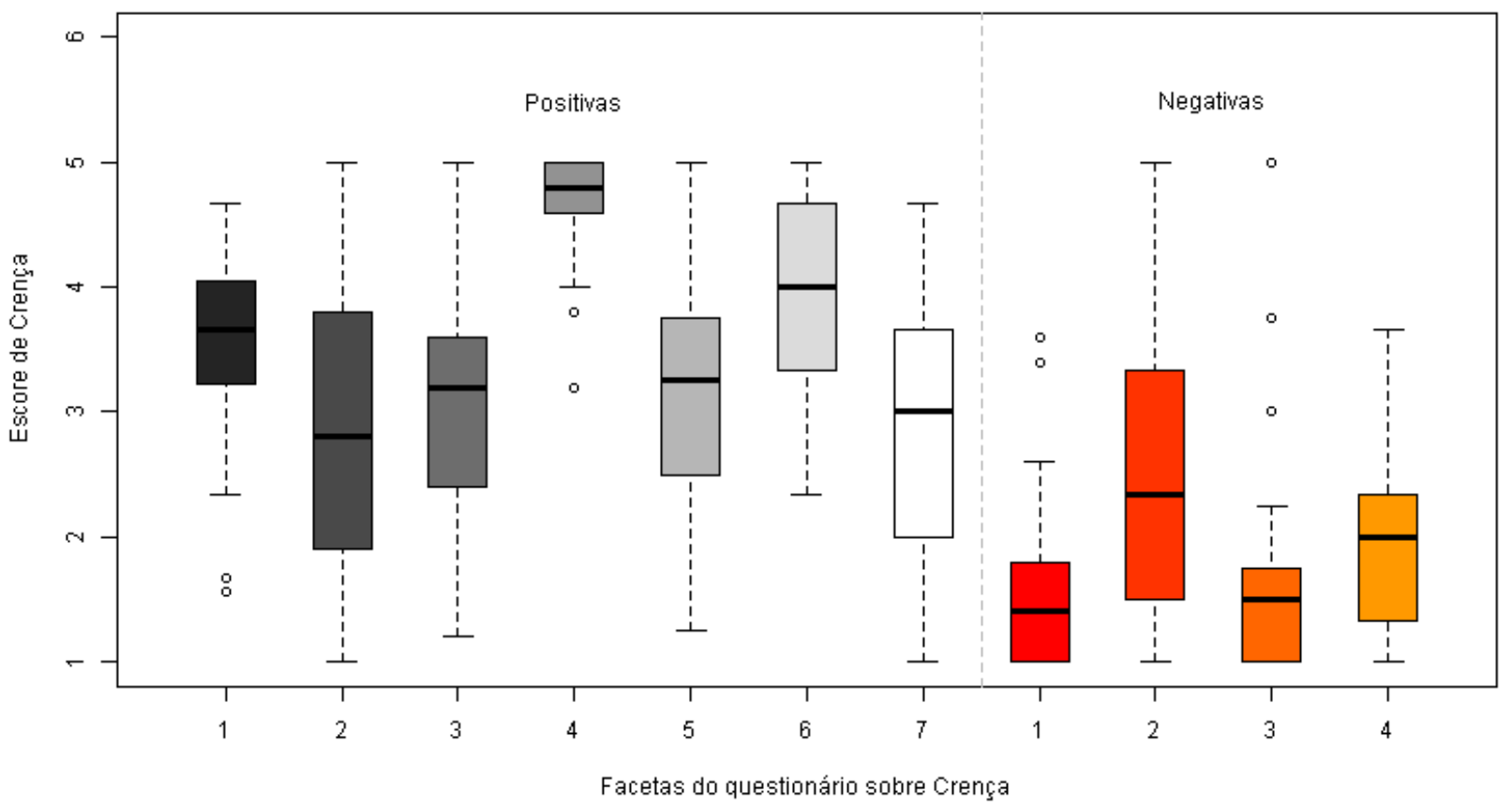

Gráfico 2 - Frequiência dos Fatores x Escores do CRE - Breve

Comparando as médias entre os fatores, o positivo obteve a maior média $(3,48)$, enquadrando-se no escore de utilização de CRE considerado médio da escala, enquanto o negativo obteve $(1,84)$, enquadrando-se no escore de utilização considerado baixo. A média dos valores de CRE total foi de $(3,82)$, refletindo um escore alto, o que significa que estas mães utilizam da estratégia de CRE para lidar com a doença da criança (Tabela 13).

Tabela - 13 Distribuição das Médias dos Fatores do CRE - Breve

\begin{tabular}{llllllll}
\hline \multirow{2}{*}{ Fatores } & $\mathrm{N}$ & Mínimo & Máximo & Média & $\begin{array}{l}\text { Desvio } \\
\text { padrão }\end{array}$ & \multicolumn{2}{c}{ IC para média (95\%) } \\
\cline { 7 - 8 } & & & & & & Inf & Sup \\
\hline $\begin{array}{l}\text { Positivo } \\
\text { Negativo }\end{array}$ & 48 & 2,09 & 4,56 & 3,48 & 0,63 & 3,29 & 3,66 \\
$\begin{array}{l}\text { Negativo } \\
\text { (invertido) }\end{array}$ & 48 & 2,13 & 3,33 & 1,84 & 0,49 & 1,70 & 1,98 \\
\hline Total & $\mathbf{4 8}$ & $\mathbf{2 , 8 7}$ & $\mathbf{4 , 6 1}$ & $\mathbf{3 , 8 2}$ & $\mathbf{0 , 3 9}$ & $\mathbf{3 , 7 1}$ & $\mathbf{3 , 9 3}$ \\
\hline \multirow{2}{*}{ Razão } & 48 & 0,29 & 1,09 & 0,55 & 0,17 & 0,50 & 0,59 \\
\hline
\end{tabular}


O total de CRE é obtido através da média entre CRE Positivo e CRE negativo invertido. O gráfico 3 demonstra que quando comparamos os dois, a maior concentração de escores 3 (mais ou menos) e 4 (bastante) compreende as questões relacionadas à faceta do CRE Positivo e quando analisamos o CRE negativo invertido, este também obtém o maior índice de escores de 4 (um pouco) a 5 (nem um pouco). O gráfico aponta que apenas três mães apresentam alguma insatisfação frente a sua crença/religião. A média total de escores do CRE demonstram que nesta amostra os escores mais utilizados estão entre 4 (bastante) quando positivo e 5 (nem um pouco) quando negativo invertido.

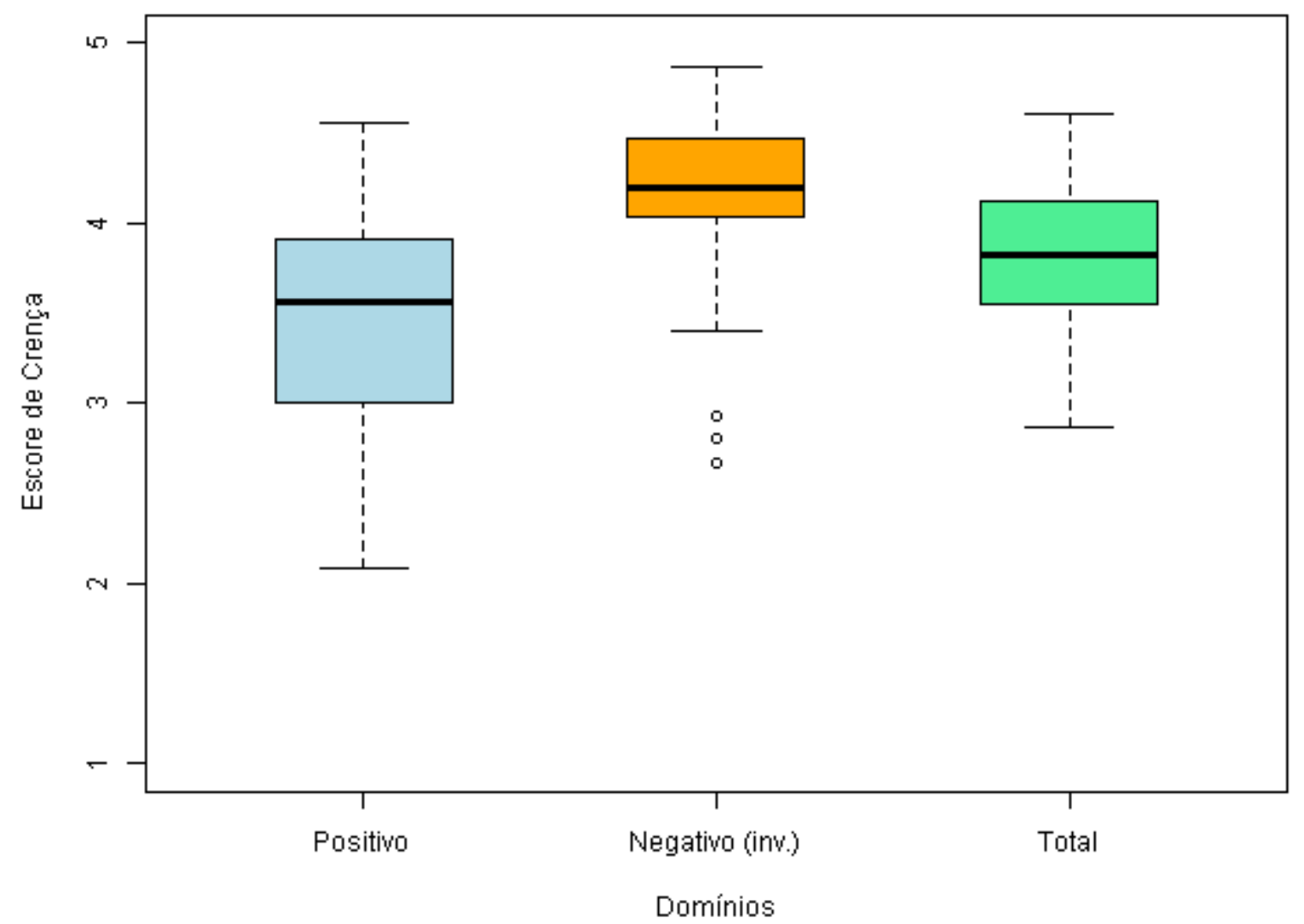

Gráfico 3 - Comparação entre CRE Positivo x CRE Negativo

O índice Razão CREN/CREP, fornece a proporção mínima necessária para se obter um balanço positivo para o indivíduo 1 CREN: 2 CREP (5). Conforme o gráfico abaixo nesta amostra este obteve um valor de Razão CREN/CREP = 0,55 (Tabela 13). 
A amostra apresentou um valor médio de 0,55 para a Razão CREN/CREP, que é compatível com a literatura. Os valores mínimos e máximos desta razão foram, respectivamente, 0,29 e 1,09. E a mediana é exatamente 0,5 , como mostra o Gráfico 4.

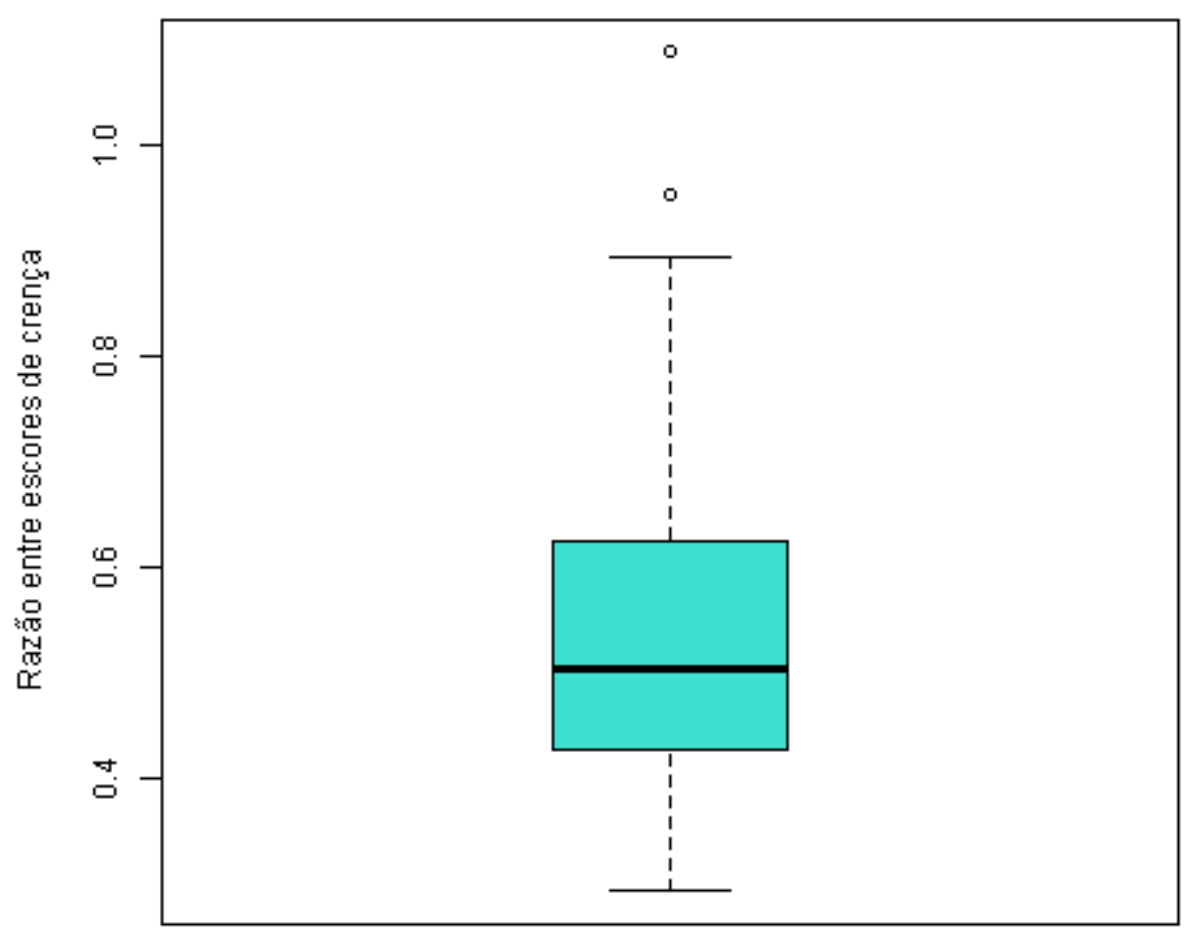

NegativoiPositivo

Gráfico 4 - Razão entre os fatores (CREN/CREP)

3.7.2 - Análise das respostas das questões que compõem o instrumento CRE - Coping Religioso Espiritual

O instrumento CRE é composto por 49 questões, 34 itens que compõem o CRE positivo e 15 que compõe o CRE negativo. Analisando os itens que compõem a escala CRE a questão Q43 - "Tentei lidar com a situação do meu jeito, sem ajuda de Deus" foi a que obteve maior média, 47 mães $(97,9)$ responderam que "nem um pouco", o item 1 (que é avaliado invertido). 
Tabela 14 - Distribuição das questões do CRE - Breve de acordo com os fatores

\section{Respostas do questionário sobre Crença - Positivo1}

\begin{tabular}{|c|c|c|c|c|c|c|c|}
\hline Item & & 1 & 2 & 3 & 4 & 5 & Total \\
\hline Cre_Q8 & & $\begin{array}{l}\text { nem um } \\
\text { pouco }\end{array}$ & um pouco & $\begin{array}{l}\text { mais ou } \\
\text { menos }\end{array}$ & bastante & muitíssimo & \\
\hline \multirow{2}{*}{$\begin{array}{l}\text { Pedi a Deus que me } \\
\text { ajudasse a encontrar um } \\
\text { novo propósito na vida }\end{array}$} & $\mathrm{N}$ & 5 & 4 & 4 & 17 & 18 & 48 \\
\hline & $\%$ & 10,5 & 8,3 & 8,3 & 35,4 & 37,5 & 100 \\
\hline Item & & 1 & 2 & 3 & 4 & 5 & Total \\
\hline Cre_Q16 & & $\begin{array}{l}\text { nem um } \\
\text { pouco }\end{array}$ & um pouco & $\begin{array}{l}\text { mais ou } \\
\text { menos }\end{array}$ & bastante & muitíssimo & \\
\hline \multirow{2}{*}{$\begin{array}{l}\text { Voltei-me a Deus para } \\
\text { encontrar uma nova } \\
\text { direção de vida }\end{array}$} & $\mathrm{N}$ & 2 & 5 & 3 & 19 & 19 & 48 \\
\hline & $\%$ & 4,2 & 10,4 & 6,2 & 39,6 & 39,6 & 100 \\
\hline Item & & 1 & 2 & 3 & 4 & 5 & Total \\
\hline Cre_Q20 & & $\begin{array}{l}\text { nem um } \\
\text { pouco }\end{array}$ & um pouco & $\begin{array}{l}\text { mais ou } \\
\text { menos }\end{array}$ & bastante & muitíssimo & \\
\hline \multirow{2}{*}{$\begin{array}{l}\text { Pedi para Deus me ajudar a } \\
\text { ser melhor e errar menos }\end{array}$} & $\mathrm{N}$ & 2 & 5 & 4 & 19 & 18 & 48 \\
\hline & $\%$ & 4,2 & 10,4 & 8,3 & 39,6 & 37,5 & 100 \\
\hline Item & & 1 & 2 & 3 & 4 & 5 & Total \\
\hline Cre_Q21 & & $\begin{array}{l}\text { nem um } \\
\text { pouco }\end{array}$ & um pouco & $\begin{array}{l}\text { mais ou } \\
\text { menos }\end{array}$ & bastante & muitíssimo & \\
\hline \multirow{2}{*}{$\begin{array}{l}\text { Pensei que o acontecido } \\
\text { poderia me aproximar mais } \\
\text { de Deus }\end{array}$} & $\mathrm{N}$ & 4 & 4 & 3 & 15 & 22 & 48 \\
\hline & $\%$ & 8,5 & 8,3 & 6,2 & 31,2 & 45,8 & 100 \\
\hline Item & & 1 & 2 & 3 & 4 & 5 & Total \\
\hline Cre_Q25 & & $\begin{array}{l}\text { nem um } \\
\text { pouco }\end{array}$ & um pouco & $\begin{array}{l}\text { mais ou } \\
\text { menos }\end{array}$ & bastante & muitíssimo & \\
\hline \multirow{2}{*}{$\begin{array}{l}\text { Orei para descobrir o } \\
\text { objetivo de minha vida }\end{array}$} & $\mathrm{N}$ & 5 & 4 & 3 & 23 & 13 & 48 \\
\hline & $\%$ & 10,5 & 8,3 & 6,2 & 47,9 & 27,1 & 100 \\
\hline Item & & 1 & 2 & 3 & 4 & 5 & Total \\
\hline Cre_Q29 & & $\begin{array}{l}\text { nem um } \\
\text { pouco }\end{array}$ & um pouco & $\begin{array}{l}\text { mais ou } \\
\text { menos }\end{array}$ & bastante & muitíssimo & \\
\hline $\begin{array}{l}\text { Procurei por um total re- } \\
\text { despertar espiritual }\end{array}$ & $\begin{array}{l}\mathrm{N} \\
\%\end{array}$ & $\begin{array}{l}12 \\
24,9\end{array}$ & $\begin{array}{l}7 \\
14,6\end{array}$ & $\begin{array}{l}8 \\
16,7\end{array}$ & $\begin{array}{l}13 \\
27,1\end{array}$ & $\begin{array}{l}8 \\
16,7\end{array}$ & $\begin{array}{l}48 \\
100\end{array}$ \\
\hline
\end{tabular}




\begin{tabular}{|c|c|c|c|c|c|c|c|}
\hline Item & & $\mathbf{1}$ & 2 & 3 & 4 & 5 & Total \\
\hline Cre_Q35 & & $\begin{array}{l}\text { nem um } \\
\text { pouco }\end{array}$ & um pouco & $\begin{array}{l}\text { mais ou } \\
\text { menos }\end{array}$ & bastante & muitíssimo & \\
\hline \multirow{2}{*}{$\begin{array}{l}\text { Pedi perdão pelos meus } \\
\text { erros }\end{array}$} & $\mathrm{N}$ & 1 & 3 & 4 & 15 & 25 & 48 \\
\hline & $\%$ & 2,2 & 6,2 & 8,3 & 31,2 & 52,1 & 100 \\
\hline Item & & 1 & 2 & 3 & 4 & 5 & Total \\
\hline Cre_Q47 & & $\begin{array}{l}\text { nem um } \\
\text { pouco }\end{array}$ & um pouco & $\begin{array}{l}\text { mais ou } \\
\text { menos }\end{array}$ & bastante & muitíssimo & \\
\hline \multirow{2}{*}{$\begin{array}{l}\text { Tentei mudar meu } \\
\text { caminho de vida e segui } \\
\text { um novo - o caminho de } \\
\text { Deus }\end{array}$} & $\mathrm{N}$ & 11 & 6 & 6 & 18 & 7 & 48 \\
\hline & $\%$ & 22,9 & 12,5 & 12,5 & 37,5 & 14,6 & 100 \\
\hline Item & & 1 & 2 & 3 & 4 & 5 & Total \\
\hline Cre_Q49 & & $\begin{array}{l}\text { nem um } \\
\text { pouco }\end{array}$ & um pouco & $\begin{array}{l}\text { mais ou } \\
\text { menos }\end{array}$ & bastante & muitíssimo & \\
\hline Refleti se não estava indo & $\mathrm{N}$ & 21 & 14 & 4 & 7 & 2 & 48 \\
\hline $\begin{array}{l}\text { contra as leis de Deus e } \\
\text { tentei modificar minha } \\
\text { atitude }\end{array}$ & $\%$ & 43,7 & 29,2 & 8,3 & 14,6 & 4,2 & 100 \\
\hline
\end{tabular}

Respostas do questionário sobre Crença - Positivo 2

\begin{tabular}{|c|c|c|c|c|c|c|c|}
\hline Item & & 1 & 2 & 3 & 4 & 5 & Total \\
\hline Cre_Q5 & & \begin{tabular}{|l} 
nem um \\
pouco
\end{tabular} & um pouco & $\begin{array}{l}\text { mais ou } \\
\text { menos }\end{array}$ & bastante & muitíssimo & \\
\hline \multirow{2}{*}{$\begin{array}{l}\text { Procurei ou realizei } \\
\text { tratamentos espirituais }\end{array}$} & $\mathrm{N}$ & 16 & 6 & 4 & 10 & 12 & 48 \\
\hline & $\%$ & 33,4 & 12,5 & 8,3 & 20,8 & 25 & 100 \\
\hline Item & & 1 & 2 & 3 & 4 & 5 & Total \\
\hline Cre_Q15 & & $\begin{array}{l}\text { nem um } \\
\text { pouco }\end{array}$ & um pouco & $\begin{array}{l}\text { mais ou } \\
\text { menos }\end{array}$ & bastante & muitíssimo & \\
\hline \multirow{2}{*}{$\begin{array}{l}\text { Procurei me aconselhar } \\
\text { com meu guia espiritual } \\
\text { superior (anjo da guarda, } \\
\text { mentor, etc) }\end{array}$} & $\mathrm{N}$ & 4 & 7 & 2 & 16 & 19 & 48 \\
\hline & $\%$ & 8,3 & 14,6 & 4,2 & 33,3 & 39,6 & 100 \\
\hline Item & & 1 & 2 & 3 & 4 & 5 & Total \\
\hline Cre_Q27 & & $\begin{array}{l}\text { nem um } \\
\text { pouco }\end{array}$ & um pouco & $\begin{array}{l}\text { mais ou } \\
\text { menos }\end{array}$ & bastante & muitíssimo & \\
\hline \multirow{2}{*}{$\begin{array}{l}\text { Busquei proteção e } \\
\text { orientação de entidades } \\
\text { espirituais (santos, } \\
\text { espíritos, orixás, etc) }\end{array}$} & $\mathrm{N}$ & 18 & 3 & 2 & 17 & 8 & 48 \\
\hline & $\%$ & 37,5 & 6,2 & 4,2 & 35,4 & 16,7 & 100 \\
\hline
\end{tabular}




\begin{tabular}{|c|c|c|c|c|c|c|c|}
\hline Item & & 1 & 2 & 3 & 4 & 5 & Total \\
\hline Cre_Q36 & & \begin{tabular}{|l} 
nem um \\
pouco
\end{tabular} & um pouco & $\begin{array}{l}\text { mais ou } \\
\text { menos }\end{array}$ & bastante & muitíssimo & \\
\hline \multirow{2}{*}{$\begin{array}{l}\text { Participei de sessões de } \\
\text { cura espiritual }\end{array}$} & $\mathrm{N}$ & 33 & 6 & 1 & 4 & 4 & 48 \\
\hline & $\%$ & 68,8 & 12,5 & 2,1 & 8,3 & 8,3 & 100 \\
\hline Item & & 1 & 2 & 3 & 4 & 5 & Total \\
\hline Cre_Q42 & & $\begin{array}{l}\text { nem um } \\
\text { pouco }\end{array}$ & um pouco & $\begin{array}{l}\text { mais ou } \\
\text { menos }\end{array}$ & bastante & muitíssimo & \\
\hline \multirow{2}{*}{$\begin{array}{l}\text { Recebi ajuda através de } \\
\text { imposição das mãos } \\
\text { (passes, rezas,bênçãos, } \\
\text { magnetismo, reike, etc.) }\end{array}$} & $\mathrm{N}$ & 10 & 9 & 5 & 16 & 8 & 48 \\
\hline & $\%$ & 20,8 & 18,8 & 10,4 & 33,3 & 16,7 & 100 \\
\hline
\end{tabular}

\section{Respostas do questionário sobre Crença - Positivo 3}

\begin{tabular}{|c|c|c|c|c|c|c|c|}
\hline Item & & 1 & 2 & 3 & 4 & 5 & Total \\
\hline Cre_Q1 & & $\begin{array}{l}\text { nem um } \\
\text { pouco }\end{array}$ & um pouco & \begin{tabular}{|l} 
mais ou \\
menos
\end{tabular} & bastante & muitíssimo & \\
\hline \multirow{2}{*}{$\begin{array}{l}\text { Orei pelo bem-estar de } \\
\text { outros }\end{array}$} & $\mathrm{N}$ & 2 & 10 & 4 & 14 & 18 & 48 \\
\hline & $\%$ & 4,2 & 20,8 & 8,3 & 29,2 & 37,5 & 100 \\
\hline Item & & 1 & 2 & 3 & 4 & 5 & Total \\
\hline Cre_Q4 & & $\begin{array}{l}\text { nem um } \\
\text { pouco }\end{array}$ & um pouco & $\begin{array}{l}\text { mais ou } \\
\text { menos }\end{array}$ & bastante & muitíssimo & \\
\hline \multirow{2}{*}{$\begin{array}{l}\text { Procurei trabalhar pelo } \\
\text { bem-estar social }\end{array}$} & $\mathrm{N}$ & 12 & 8 & 8 & 15 & 5 & 48 \\
\hline & $\%$ & 25 & 16,7 & 16,7 & 31,2 & 10,4 & 100 \\
\hline Item & & 1 & 2 & 3 & 4 & 5 & Total \\
\hline Cre_Q14 & & \begin{tabular}{|l|} 
nem um \\
pouco
\end{tabular} & um pouco & $\begin{array}{l}\text { mais ou } \\
\text { menos }\end{array}$ & bastante & muitíssimo & \\
\hline \multirow{2}{*}{$\begin{array}{l}\text { Pratiquei atos de caridade } \\
\text { moral e/ou material }\end{array}$} & $\mathrm{N}$ & 8 & 9 & 7 & 18 & 6 & 48 \\
\hline & $\%$ & 16,6 & 18,8 & 14,6 & 37,5 & 12,5 & 100 \\
\hline Item & & 1 & 2 & 3 & 4 & 5 & Total \\
\hline Cre_Q18 & & $\begin{array}{l}\text { nem um } \\
\text { pouco }\end{array}$ & um pouco & $\begin{array}{l}\text { mais ou } \\
\text { menos }\end{array}$ & bastante & muitíssimo & \\
\hline \multirow{2}{*}{$\begin{array}{l}\text { Tentei proporcionar } \\
\text { conforto espiritual a outras } \\
\text { pessoas }\end{array}$} & $\mathrm{N}$ & 7 & 7 & 9 & 18 & 7 & 48 \\
\hline & $\%$ & 14,5 & 14,6 & 18,8 & 37,5 & 14,6 & 100 \\
\hline
\end{tabular}




\begin{tabular}{l|l|l|l|l|l|l|l}
\hline Item & & $\mathbf{1}$ & $\mathbf{2}$ & $\mathbf{3}$ & $\mathbf{4}$ & $\mathbf{5}$ & Total \\
\hline Cre_Q39 & & $\begin{array}{l}\text { nem um } \\
\text { pouco }\end{array}$ & um pouco & $\begin{array}{l}\text { mais ou } \\
\text { menos }\end{array}$ & bastante & muitíssimo & \\
\hline $\begin{array}{l}\text { Envolvi-me } \\
\text { voluntariamente em } \\
\text { atividades pelo bem do } \\
\text { próximo }\end{array}$ & $\mathrm{N}$ & 16 & 11 & 8 & 9 & 4 & 48 \\
\cline { 2 - 8 } & & & & & & & \\
\end{tabular}

\section{Respostas do questionário sobre Crença - Positivo 4}

\begin{tabular}{|c|c|c|c|c|c|c|c|}
\hline Item & & 1 & 2 & 3 & 4 & 5 & Total \\
\hline Cre_Q2 & & $\begin{array}{l}\text { nem um } \\
\text { pouco }\end{array}$ & um pouco & $\begin{array}{l}\text { mais ou } \\
\text { menos }\end{array}$ & bastante & muitíssimo & \\
\hline \multirow{2}{*}{$\begin{array}{l}\text { Procurei o amor e a } \\
\text { proteção de Deus }\end{array}$} & $\mathrm{N}$ & 0 & 2 & 2 & 12 & 32 & 48 \\
\hline & $\%$ & 0 & 4,2 & 4,2 & 25 & 66,8 & 100 \\
\hline Item & & 1 & 2 & 3 & 4 & 5 & Total \\
\hline Cre_Q6 & & \begin{tabular}{|l|} 
nem um \\
pouco
\end{tabular} & um pouco & $\begin{array}{l}\text { mais ou } \\
\text { menos }\end{array}$ & bastante & muitíssimo & \\
\hline \multirow{2}{*}{$\begin{array}{l}\text { Procurei em Deus força, } \\
\text { apoio e orientação }\end{array}$} & $\mathrm{N}$ & 0 & 2 & 1 & 9 & 36 & 48 \\
\hline & $\%$ & 0 & 4,2 & 2,1 & 18,8 & 75,1 & 100 \\
\hline Item & & 1 & 2 & 3 & 4 & 5 & Total \\
\hline Cre_Q17_inv * & & $\begin{array}{l}\text { nem um } \\
\text { pouco }\end{array}$ & um pouco & $\begin{array}{l}\text { mais ou } \\
\text { menos }\end{array}$ & bastante & muitíssimo & \\
\hline \multirow{2}{*}{$\begin{array}{l}\text { Tentei lidar com meus } \\
\text { sentimentos sem pedir a } \\
\text { ajuda de Deus }\end{array}$} & $\mathrm{N}$ & 42 & 2 & 1 & 3 & 0 & 48 \\
\hline & $\%$ & 87,5 & 4,2 & 2,1 & 6,2 & 0 & 100 \\
\hline Item & & 1 & 2 & 3 & 4 & 5 & Total \\
\hline Cre_Q30 & & $\begin{array}{l}\text { nem um } \\
\text { pouco }\end{array}$ & um pouco & $\begin{array}{l}\text { mais ou } \\
\text { menos }\end{array}$ & bastante & muitíssimo & \\
\hline \multirow{2}{*}{$\begin{array}{l}\text { Confiei que Deus estava } \\
\text { comigo }\end{array}$} & $\mathrm{N}$ & 0 & 1 & 2 & 10 & 35 & 48 \\
\hline & $\%$ & 0 & 2,1 & 4,2 & 20,8 & 72,9 & 100 \\
\hline Item & & 1 & 2 & 3 & 4 & 5 & Total \\
\hline Cre_Q43_inv * & & \begin{tabular}{|l|} 
nem um \\
pouco
\end{tabular} & um pouco & $\begin{array}{l}\text { mais ou } \\
\text { menos }\end{array}$ & bastante & muitíssimo & \\
\hline \multirow{2}{*}{$\begin{array}{l}\text { Tentei lidar com a situação } \\
\text { do meu jeito, sem a ajuda } \\
\text { de Deus }\end{array}$} & $\mathrm{N}$ & 47 & 1 & 0 & 0 & 0 & 48 \\
\hline & $\%$ & 97,9 & 2,1 & 0 & 0 & 0 & 100 \\
\hline
\end{tabular}




\section{Respostas do questionário sobre Crença - Positivo 5}

\begin{tabular}{|c|c|c|c|c|c|c|c|}
\hline Item & & 1 & 2 & 3 & 4 & 5 & Total \\
\hline Cre_Q8 & & $\begin{array}{l}\text { nem um } \\
\text { pouco }\end{array}$ & um pouco & $\begin{array}{l}\text { mais ou } \\
\text { menos }\end{array}$ & bastante & muitíssimo & \\
\hline \multirow{2}{*}{$\begin{array}{l}\text { Pedi a Deus que me } \\
\text { ajudasse a encontrar um } \\
\text { novo propósito na vida }\end{array}$} & $\mathrm{N}$ & 5 & 4 & 4 & 17 & 18 & 48 \\
\hline & $\%$ & 10,5 & 8,3 & 8,3 & 35,4 & 37,5 & 100 \\
\hline Item & & 1 & 2 & 3 & 4 & 5 & Total \\
\hline Cre_Q16 & & $\begin{array}{l}\text { nem um } \\
\text { pouco }\end{array}$ & um pouco & $\begin{array}{l}\text { mais ou } \\
\text { menos }\end{array}$ & bastante & muitíssimo & \\
\hline \multirow{2}{*}{$\begin{array}{l}\text { Voltei-me a Deus para } \\
\text { encontrar uma nova } \\
\text { direção de vida }\end{array}$} & $\mathrm{N}$ & 2 & 5 & 3 & 19 & 19 & 48 \\
\hline & $\%$ & 4,2 & 10,4 & 6,2 & 39,6 & 39,6 & 100 \\
\hline Item & & 1 & 2 & 3 & 4 & 5 & Total \\
\hline Cre_Q20 & & \begin{tabular}{|l} 
nem um \\
pouco
\end{tabular} & um pouco & $\begin{array}{l}\text { mais ou } \\
\text { menos }\end{array}$ & bastante & muitíssimo & \\
\hline \multirow{2}{*}{$\begin{array}{l}\text { Pedi para Deus me ajudar a } \\
\text { ser melhor e errar menos }\end{array}$} & $\mathrm{N}$ & 2 & 5 & 4 & 19 & 18 & 48 \\
\hline & $\%$ & 4,2 & 10,4 & 8,3 & 39,6 & 37,5 & 100 \\
\hline Item & & 1 & 2 & 3 & 4 & 5 & Total \\
\hline Cre_Q21 & & $\begin{array}{l}\text { nem um } \\
\text { pouco }\end{array}$ & um pouco & $\begin{array}{l}\text { mais ou } \\
\text { menos }\end{array}$ & bastante & muitíssimo & \\
\hline \multirow{2}{*}{$\begin{array}{l}\text { Pensei que o acontecido } \\
\text { poderia me aproximar mais } \\
\text { de Deus }\end{array}$} & $\mathrm{N}$ & 4 & 4 & 3 & 15 & 22 & 48 \\
\hline & $\%$ & 8,5 & 8,3 & 6,2 & 31,2 & 45,8 & 100 \\
\hline
\end{tabular}

\section{Respostas do questionário sobre Crença - Positivo 6}

\begin{tabular}{l|l|l|l|l|l|l|l}
\hline Item & & $\mathbf{1}$ & $\mathbf{2}$ & $\mathbf{3}$ & $\mathbf{4}$ & $\mathbf{5}$ & Total \\
\hline Cre_Q12 & & $\begin{array}{l}\text { nem um } \\
\text { pouco }\end{array}$ & um pouco & $\begin{array}{l}\text { mais ou } \\
\text { menos }\end{array}$ & bastante & muitíssimo & \\
\hline $\begin{array}{l}\text { Fiz o melhor que pude e } \\
\text { entreguei a situação a Deus }\end{array}$ & $\mathbf{N}$ & 0 & 1 & 5 & 21 & 21 & 48 \\
\cline { 2 - 9 } & $\%$ & 0 & 2,1 & 10,4 & 43,9 & 43,8 & 100 \\
\hline Item & & $\mathbf{1}$ & $\mathbf{2}$ & $\mathbf{3}$ & $\mathbf{4}$ & $\mathbf{5}$ & Total \\
\hline Cre_Q24 & & $\begin{array}{l}\text { nem um } \\
\text { pouco }\end{array}$ & um pouco & $\begin{array}{l}\text { mais ou } \\
\text { menos }\end{array}$ & bastante & muitíssimo & \\
\hline $\begin{array}{l}\text { Entreguei a situação para } \\
\text { Deus depois de fazer tudo } \\
\text { que podia }\end{array}$ & $\mathrm{N}$ & 4 & 8 & 5 & 14 & 17 & 48 \\
\cline { 2 - 9 } & $\%$ & 8,3 & 16,7 & 10,4 & 29,2 & 35,4 & 100 \\
\hline
\end{tabular}




\begin{tabular}{l|l|l|l|l|l|l|l}
\hline Item & & $\mathbf{1}$ & $\mathbf{2}$ & $\mathbf{3}$ & $\mathbf{4}$ & $\mathbf{5}$ & Total \\
\hline Cre_Q38 & & $\begin{array}{l}\text { nem um } \\
\text { pouco }\end{array}$ & um pouco & $\begin{array}{l}\text { mais ou } \\
\text { menos }\end{array}$ & bastante & muitíssimo & \\
\hline $\begin{array}{l}\text { Tentei fazer o melhor que } \\
\text { podia e deixei Deus fazer } \\
\text { o resto }\end{array}$ & $\mathrm{N}$ & 1 & 6 & 6 & 19 & 16 & 48 \\
\cline { 2 - 9 } & $\%$ & 2,1 & 12,5 & 12,5 & 39,6 & 33,3 & 100 \\
\hline
\end{tabular}

\section{Respostas do questionário sobre Crença - Positivo 7}

\begin{tabular}{|c|c|c|c|c|c|c|c|}
\hline Item & & 1 & 2 & 3 & 4 & 5 & Total \\
\hline Cre_Q31 & & $\begin{array}{l}\text { nem um } \\
\text { pouco }\end{array}$ & um pouco & $\begin{array}{l}\text { mais ou } \\
\text { menos }\end{array}$ & bastante & muitíssimo & \\
\hline \multirow{2}{*}{$\begin{array}{l}\text { Comprei ou assinei } \\
\text { revistas periódicas que } \\
\text { falavam sobre Deus e } \\
\text { questões espirituais }\end{array}$} & $\mathrm{N}$ & 33 & 5 & 4 & 5 & 1 & 48 \\
\hline & $\%$ & 68,8 & 10,4 & 8,3 & 10,4 & 2,1 & 100 \\
\hline Item & & 1 & 2 & 3 & 4 & 5 & Total \\
\hline Cre_Q34 & & \begin{tabular}{|l|} 
nem um \\
pouco
\end{tabular} & um pouco & $\begin{array}{l}\text { mais ou } \\
\text { menos }\end{array}$ & bastante & muitíssimo & \\
\hline \multirow{2}{*}{$\begin{array}{l}\text { Busquei ajuda ou conforto } \\
\text { na literatura religiosa }\end{array}$} & $\mathrm{N}$ & 6 & 11 & 3 & 17 & 11 & 48 \\
\hline & $\%$ & 12,6 & 22,9 & 6,2 & 35,4 & 22,9 & 100 \\
\hline Item & & 1 & 2 & 3 & 4 & 5 & Total \\
\hline Cre_Q46 & & $\begin{array}{l}\text { nem um } \\
\text { pouco }\end{array}$ & um pouco & $\begin{array}{l}\text { mais ou } \\
\text { menos }\end{array}$ & bastante & muitíssimo & \\
\hline \multirow{2}{*}{$\begin{array}{l}\text { Procurei auxílio nos livros } \\
\text { sagrados }\end{array}$} & $\mathrm{N}$ & 10 & 3 & 4 & 18 & 13 & 48 \\
\hline & $\%$ & 20,9 & 6,2 & 8,3 & 37,5 & 27,1 & 100 \\
\hline
\end{tabular}

\section{Respostas do questionário sobre Crença - Negativo 1}

\begin{tabular}{l|l|l|l|l|l|l|l}
\hline Item & & $\mathbf{1}$ & $\mathbf{2}$ & $\mathbf{3}$ & $\mathbf{4}$ & $\mathbf{5}$ & Total \\
\hline Cre_Q19 & & $\begin{array}{l}\text { nem um } \\
\text { pouco }\end{array}$ & um pouco & $\begin{array}{l}\text { mais ou } \\
\text { menos }\end{array}$ & bastante & muitíssimo & \\
\hline $\begin{array}{l}\text { Fiquei imaginando se Deus } \\
\text { tinha me abandonado }\end{array}$ & $\mathbf{N}$ & 21 & 11 & 8 & 3 & 5 & 48 \\
\cline { 2 - 9 } & $\%$ & 43,8 & 22,9 & 16,7 & 6,2 & 10,4 & 100 \\
\hline Item & & $\mathbf{1}$ & $\mathbf{2}$ & $\mathbf{3}$ & $\mathbf{4}$ & $\mathbf{5}$ & Total \\
\hline Cre_Q32 & & $\begin{array}{l}\text { nem um } \\
\text { pouco }\end{array}$ & um pouco & $\begin{array}{l}\text { mais ou } \\
\text { menos }\end{array}$ & bastante & muitíssimo & \\
\hline $\begin{array}{l}\text { Pensei que Deus não } \\
\text { existia }\end{array}$ & $\mathrm{N}$ & 43 & 1 & 3 & 1 & 0 & 48 \\
\cline { 2 - 9 } & $\%$ & 89,6 & 2,1 & 6,2 & 2,1 & 0 & 100 \\
\hline
\end{tabular}




\begin{tabular}{|c|c|c|c|c|c|c|c|}
\hline Item & & 1 & 2 & 3 & 4 & 5 & Total \\
\hline Cre_Q33 & & $\begin{array}{l}\text { nem um } \\
\text { pouco }\end{array}$ & um pouco & $\begin{array}{l}\text { mais ou } \\
\text { menos }\end{array}$ & bastante & muitíssimo & \\
\hline \multirow{2}{*}{$\begin{array}{l}\text { Questionei se até Deus tem } \\
\text { limites }\end{array}$} & $\mathrm{N}$ & 38 & 6 & 3 & 0 & 1 & 48 \\
\hline & $\%$ & 79,2 & 12,5 & 6,2 & 0 & 2,1 & 100 \\
\hline Item & & 1 & 2 & 3 & 4 & 5 & Total \\
\hline Cre_Q37 & & $\begin{array}{l}\text { nem um } \\
\text { pouco }\end{array}$ & um pouco & $\begin{array}{l}\text { mais ou } \\
\text { menos }\end{array}$ & bastante & muitíssimo & \\
\hline \multirow{2}{*}{$\begin{array}{l}\text { Questionei se Deus } \\
\text { realmente se importava }\end{array}$} & $\mathrm{N}$ & 34 & 4 & 3 & 4 & 3 & 48 \\
\hline & $\%$ & 71 & 8,3 & 6,2 & 8,3 & 6,2 & 100 \\
\hline Item & & 1 & 2 & 3 & 4 & 5 & Total \\
\hline Cre_Q48 & & $\begin{array}{l}\text { nem um } \\
\text { pouco }\end{array}$ & um pouco & $\begin{array}{l}\text { mais ou } \\
\text { menos }\end{array}$ & bastante & muitíssimo & \\
\hline \multirow{2}{*}{$\begin{array}{l}\text { Culpei Deus pela situação, } \\
\text { por ter deixado acontecer }\end{array}$} & $\mathrm{N}$ & 43 & 2 & 1 & 1 & 1 & 48 \\
\hline & $\%$ & 89,5 & 4,2 & 2,1 & 2,1 & 2,1 & 100 \\
\hline
\end{tabular}

\section{Respostas do questionário sobre Crença - Negativo 2}

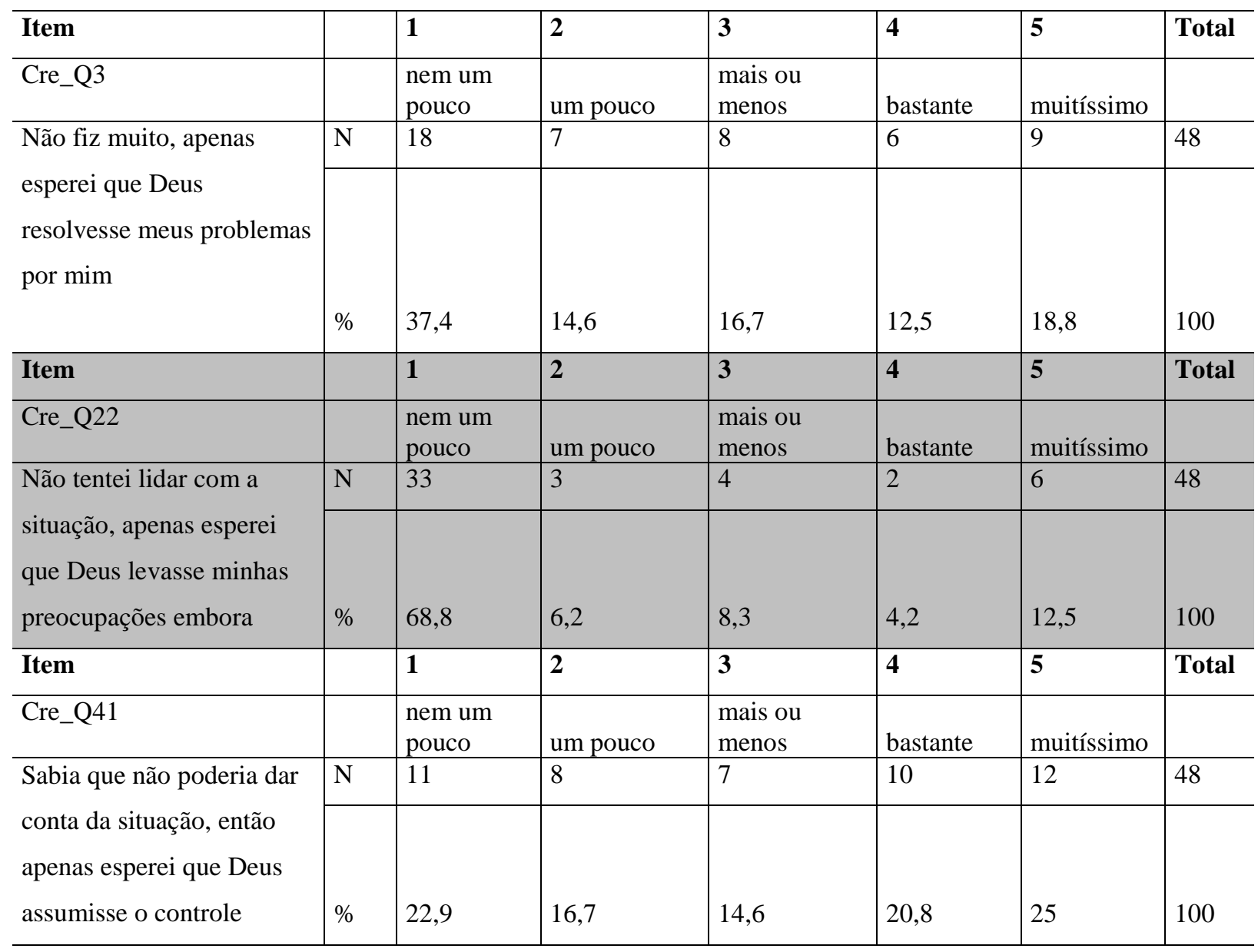




\begin{tabular}{|c|c|c|c|c|c|c|c|}
\hline Item & & 1 & 2 & 3 & 4 & 5 & Total \\
\hline Cre_Q7 & & $\begin{array}{l}\text { nem um } \\
\text { pouco }\end{array}$ & um pouco & $\begin{array}{l}\text { mais ou } \\
\text { menos }\end{array}$ & bastante & muitíssimo & \\
\hline \multirow{2}{*}{$\begin{array}{l}\text { Senti insatisfação com os } \\
\text { representantes religiosos } \\
\text { de minha instituição }\end{array}$} & $\bar{N}$ & 30 & 5 & 5 & 5 & 3 & 48 \\
\hline & $\%$ & 62,6 & 10,4 & 10,4 & 10,4 & 6,2 & 100 \\
\hline Item & & 1 & 2 & 3 & 4 & 5 & Total \\
\hline Cre_Q11 & & $\begin{array}{l}\text { nem um } \\
\text { pouco }\end{array}$ & um pouco & $\begin{array}{l}\text { mais ou } \\
\text { menos }\end{array}$ & bastante & muitíssimo & \\
\hline \multirow{2}{*}{$\begin{array}{l}\text { Tive dificuldades para } \\
\text { receber conforto de minhas } \\
\text { crenças religiosas }\end{array}$} & $\mathrm{N}$ & 35 & 3 & 5 & 3 & 2 & 48 \\
\hline & $\%$ & 73 & 6,2 & 10,4 & 6,2 & 4,2 & 100 \\
\hline Item & & 1 & 2 & 3 & 4 & 5 & Total \\
\hline Cre_Q28 & & $\begin{array}{l}\text { nem um } \\
\text { pouco }\end{array}$ & um pouco & $\begin{array}{l}\text { mais ou } \\
\text { menos }\end{array}$ & bastante & muitíssimo & \\
\hline \multirow{2}{*}{$\begin{array}{l}\text { Imaginei se minha } \\
\text { instituição religiosa tinha } \\
\text { me abandonado }\end{array}$} & $\mathrm{N}$ & 39 & 2 & 2 & 2 & 3 & 48 \\
\hline & $\%$ & 81,2 & 4,2 & 4,2 & 4,2 & 6,2 & 100 \\
\hline Item & & 1 & 2 & 3 & 4 & 5 & Total \\
\hline Cre_Q44 & & \begin{tabular}{|l} 
nem um \\
pouco
\end{tabular} & um pouco & $\begin{array}{l}\text { mais ou } \\
\text { menos }\end{array}$ & bastante & muitíssimo & \\
\hline Senti que meu grupo & $\mathrm{N}$ & 42 & 2 & 0 & 2 & 2 & 48 \\
\hline $\begin{array}{l}\text { religioso parecia estar me } \\
\text { rejeitando ou me } \\
\text { ignorando }\end{array}$ & $\%$ & 87,4 & 4,2 & 0 & 4,2 & 4,2 & 100 \\
\hline
\end{tabular}

\section{Respostas do questionário sobre Crença - Negativo 3}

\begin{tabular}{|c|c|c|c|c|c|c|c|}
\hline Item & & 1 & 2 & 3 & 4 & 5 & Total \\
\hline Cre_Q9 & & $\begin{array}{l}\text { nem um } \\
\text { pouco }\end{array}$ & um pouco & $\begin{array}{l}\text { mais ou } \\
\text { menos }\end{array}$ & bastante & muitíssimo & \\
\hline \multirow{2}{*}{$\begin{array}{l}\text { Imaginei se Deus permitiu } \\
\text { que isso me acontecesse } \\
\text { por causa dos meus erros }\end{array}$} & $\mathrm{N}$ & 13 & 7 & 8 & 9 & 11 & 48 \\
\hline & $\%$ & 27 & 14,6 & 16,7 & 18,8 & 22,9 & 100 \\
\hline Item & & 1 & 2 & 3 & 4 & 5 & Total \\
\hline Cre_Q13 & & $\begin{array}{l}\text { nem um } \\
\text { pouco }\end{array}$ & um pouco & $\begin{array}{l}\text { mais ou } \\
\text { menos }\end{array}$ & bastante & muitíssimo & \\
\hline \multirow{2}{*}{$\begin{array}{l}\text { Convenci-me que forças } \\
\text { do mal atuaram para tudo } \\
\text { isso acontecer }\end{array}$} & $\mathrm{N}$ & 39 & 5 & 1 & 2 & 1 & 48 \\
\hline & $\%$ & 81,2 & 10,4 & 2,1 & 4,2 & 2,1 & 100 \\
\hline
\end{tabular}




\begin{tabular}{l|l|l|l|l|l|l|l}
\hline Item & & $\mathbf{1}$ & $\mathbf{2}$ & $\mathbf{3}$ & $\mathbf{4}$ & $\mathbf{5}$ & Total \\
\hline Cre_Q23 & & $\begin{array}{l}\text { nem um } \\
\text { pouco }\end{array}$ & um pouco & $\begin{array}{l}\text { mais ou } \\
\text { menos }\end{array}$ & bastante & muitíssimo & \\
\hline $\begin{array}{l}\text { Senti que o mal estava } \\
\text { tentando me afastar de }\end{array}$ & $\mathrm{N}$ & 27 & 12 & 5 & 2 & 2 & 48 \\
\cline { 2 - 8 } \begin{tabular}{l} 
Deus \\
\hline
\end{tabular} & $\%$ & 56,2 & 25 & 10,4 & 4,2 & 4,2 & 100 \\
\hline
\end{tabular}

* Itens com sistema de pontuação inversa

\section{8 - Correlação entre Qualidade de Vida x Coping Religioso Espiritual}

3.8.1 - Analise das correlações entre os domínios do instrumento WHOQOL - Breve

A correlação entre os domínios foi avaliada através da Correlação de Pearson. O único domínio que apresentou correlação com os demais foi: o domínio 4 com o domínio $3(r=0,50)$ e o domínio 4 com o domínio $2(\mathrm{r}=0,51)$.

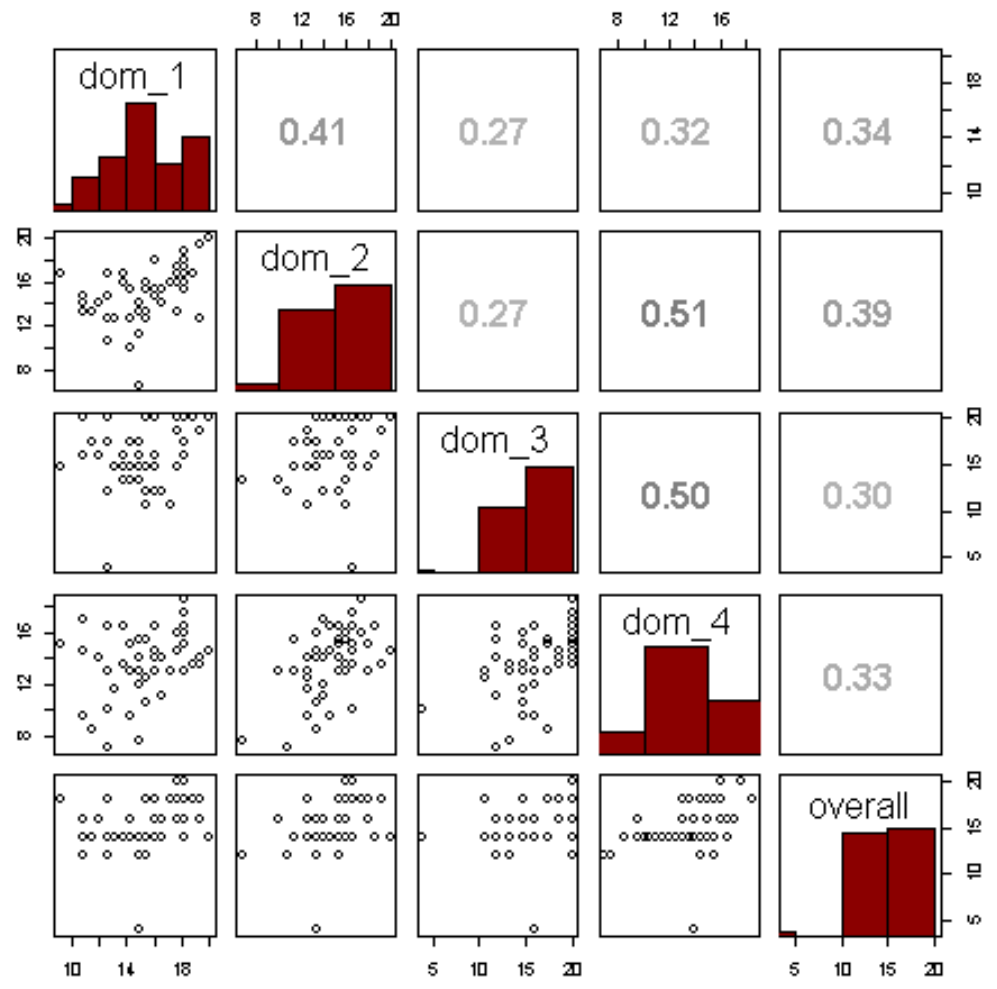

Gráfico 5 - Correlação entre os domínios do WHOQOL - Breve na amostra 
3.8.2 - Analise das correlações entre os fatores positivos x negativos do instrumento CRE Coping Religioso Espiritual na amostra
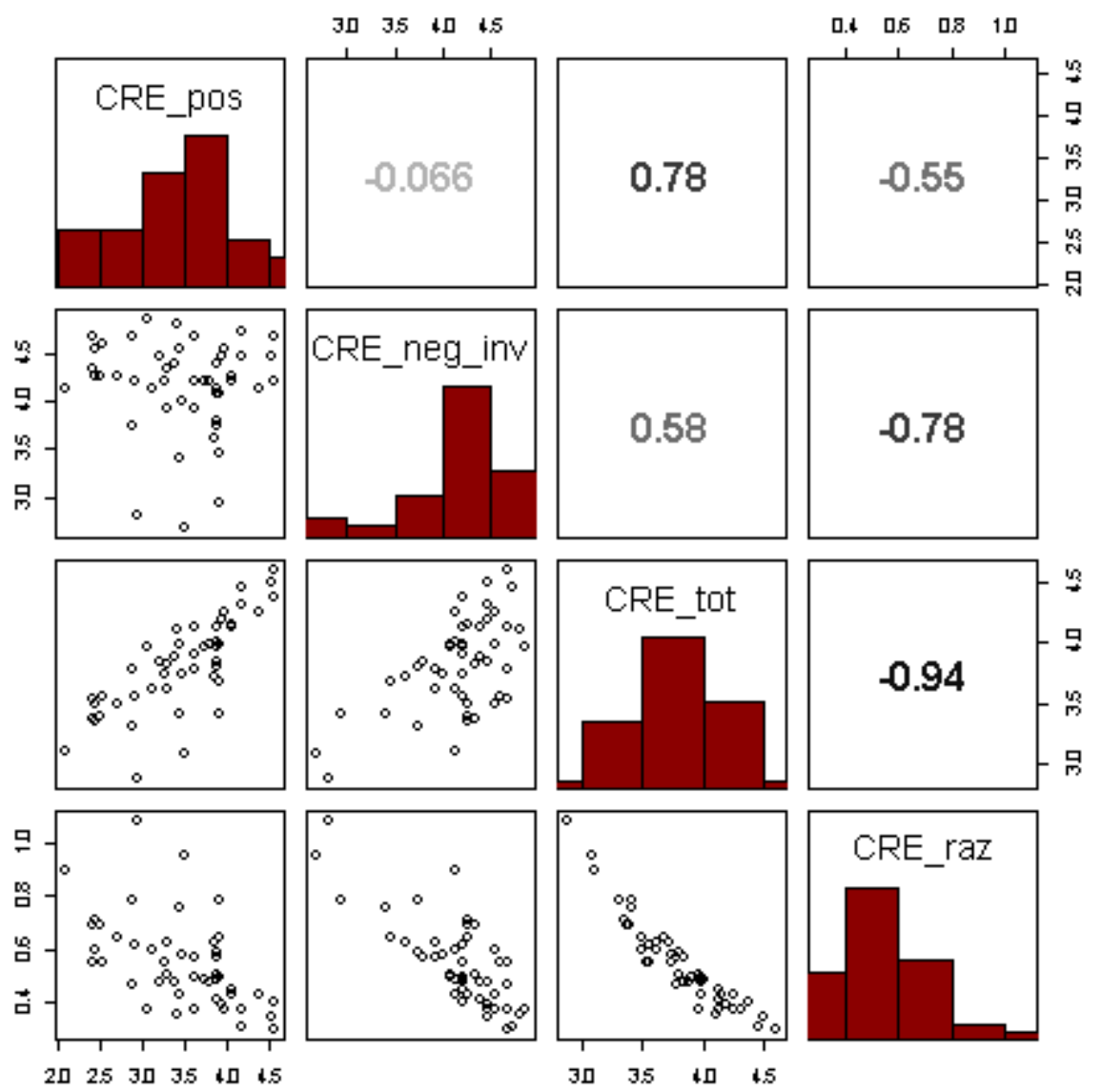

Gráfico 6 - Correlação entre os fatores do CRE - Breve na amostra

Quando analisamos a correlação entre as Dimensões da Escala CRE, podemos observar que existe correlação entre o CRE total e o CRE negativo - inv $(r=0,58)$ e entre o CRE total e o CRE positivo $(r=0,78)$. Em relação à razão entre os CREs também existe uma correlação negativa significativa com o CRE total $(r=-0,94)$ e com o CRE negativo - inv $(r=-0,78)$. 
3.8.3 - Correlação entre os instrumentos de Qualidade de Vida WHOQOL- Breve e o instrumento Coping Religioso Espiritual na amostra

Analisando a correlação entre Qualidade de Vida e Coping Religioso Espiritual a tabela abaixo demonstra que o CRE positivo se correlaciona com todos os domínios do Instrumento de Qualidade de Vida - WHOQOL-Breve: dom $1(\mathrm{r}=0,384)$, dom $2(\mathrm{r}=0,435)$, dom $3(\mathrm{r}=0,416)$ e dom $4(\mathrm{r}=0,423)$. O CRE total também apresentou correlação com os domínios do WHOQOLBreve: dom $1(r=0,325)$, dom $2(r=0407)$, dom $3(r=0,336)$ e dom $4(r=0,295)$ Enquanto que o CRE negativo invertido não apresentou correlação alguma com qualidade de vida (Tabela 14). Dados estes confirmados através do teste de nulidade descrito na tabela 15.

Tabela 15 - Correlação de Pearson entre domínios de QV e CRE

\begin{tabular}{llllll}
\hline & dom_1 & Dom_2 & Dom_3 & Dom_4 & overall \\
\hline CRE_pos & $\mathbf{0 , 3 8 4} *$ & $\mathbf{0 , 4 3 5} *$ & $\mathbf{0 , 4 1 6} *$ & $\mathbf{0 , 4 2 3} *$ & $\mathbf{0 , 3 1 5}$ \\
CRE_neg_inv & 0,016 & 0,079 & $-0,008$ & $-0,082$ & $-0,091$ \\
CRE_tot & $\mathbf{0 , 3 2 5 *}$ & $\mathbf{0 , 4 0 7} *$ & $\mathbf{0 , 3 3 6} *$ & $\mathbf{0 , 2 9 5} *$ & 0,2 \\
CRE_raz & $-0,232$ & $\mathbf{- 0 , 2 8 5}$ & $-0,226$ & $-0,16$ & $-0,084$ \\
\hline P1 & 0,258 & $\mathbf{0 , 3 0 7}$ & $\mathbf{0 , 4 8 7}$ & $\mathbf{0 , 3 3 7}$ & 0,267 \\
P2 & $\mathbf{0 , 3 5}$ & 0,266 & 0,28 & $\mathbf{0 , 3 6 9}$ & 0,243 \\
P3 & 0,252 & $\mathbf{0 , 4 0 3}$ & $\mathbf{0 , 3 6 4}$ & $\mathbf{0 , 3 6 2}$ & 0,168 \\
P4 & 0,16 & 0,219 & 0,079 & 0,197 & $\mathbf{0 , 2 8 6}$ \\
P5 & $\mathbf{0 , 3 0 2}$ & $\mathbf{0 , 4 1 5}$ & 0,251 & 0,235 & 0,27 \\
P6 & $\mathbf{0 , 3 5 3}$ & $\mathbf{0 , 3 2 6}$ & 0,199 & $\mathbf{0 , 3 6 7}$ & 0,224 \\
P7 & $\mathbf{0 , 3 1 1}$ & $\mathbf{0 , 3 1}$ & 0,241 & 0,252 & 0,193 \\
\hline N1 & $-0,105$ & $-0,115$ & 0,17 & 0,001 & 0,085 \\
N2 & 0,29 & 0,249 & $-0,025$ & 0,099 & 0,237 \\
N3 & $-0,091$ & $-0,147$ & $-0,12$ & 0,145 & $-0,141$ \\
N4 & $-0,216$ & $-0,261$ & 0,018 & $-0,105$ & 0,036 \\
\hline \multicolumn{7}{l}{$>$ P } & & & & \\
* Correlação significativa & & & &
\end{tabular}


Tabela 16 - Caracterização do valor de p no teste de nulidade das Correlações de Pearson entre domínios de QV e CRE

\begin{tabular}{llllll}
\hline & dom_1 & Dom_2 & Dom_3 & dom_4 & overall \\
\hline CRE_pos & $\mathbf{0 , 0 0 7}$ & $\mathbf{0 , 0 0 2}$ & $\mathbf{0 , 0 0 3}$ & $\mathbf{0 , 0 0 3}$ & $\mathbf{0 , 0 2 9}$ \\
CRE_neg_inv & 0,916 & 0,593 & 0,959 & 0,578 & 0,538 \\
CRE_tot & $\mathbf{0 , 0 2 4}$ & $\mathbf{0 , 0 0 4}$ & $\mathbf{0 , 0 2}$ & $\mathbf{0 , 0 4 2}$ & 0,172 \\
CRE_raz & 0,112 & $\mathbf{0 , 0 4 9}$ & 0,122 & 0,277 & 0,57 \\
\hline P1 & 0,077 & $\mathbf{0 , 0 3 4}$ & $\mathbf{0}$ & $\mathbf{0 , 0 1 9}$ & 0,066 \\
P2 & $\mathbf{0 , 0 1 5}$ & 0,068 & 0,054 & $\mathbf{0 , 0 1}$ & 0,095 \\
P3 & 0,083 & $\mathbf{0 , 0 0 4}$ & $\mathbf{0 , 0 1 1}$ & $\mathbf{0 , 0 1 1}$ & 0,253 \\
P4 & 0,277 & 0,134 & 0,593 & 0,179 & $\mathbf{0 , 0 4 9}$ \\
P5 & $\mathbf{0 , 0 3 7}$ & $\mathbf{0 , 0 0 3}$ & 0,085 & 0,109 & 0,064 \\
P6 & $\mathbf{0 , 0 1 4}$ & $\mathbf{0 , 0 2 4}$ & 0,174 & $\mathbf{0 , 0 1}$ & 0,126 \\
P7 & $\mathbf{0 , 0 3 1}$ & $\mathbf{0 , 0 3 2}$ & 0,099 & 0,084 & 0,189 \\
\hline N1 & 0,476 & 0,435 & 0,248 & 0,997 & 0,567 \\
N2 & $\mathbf{0 , 0 4 6}$ & 0,088 & 0,868 & 0,504 & 0,104 \\
N3 & 0,54 & 0,318 & 0,417 & 0,324 & 0,338 \\
N4 & 0,141 & 0,073 & 0,905 & 0,479 & 0,808 \\
\hline
\end{tabular}

O gráfico 7 apresenta as correlações descritas na tabela 15 e confirmadas na tabela 16 pelo teste de nulidade. 

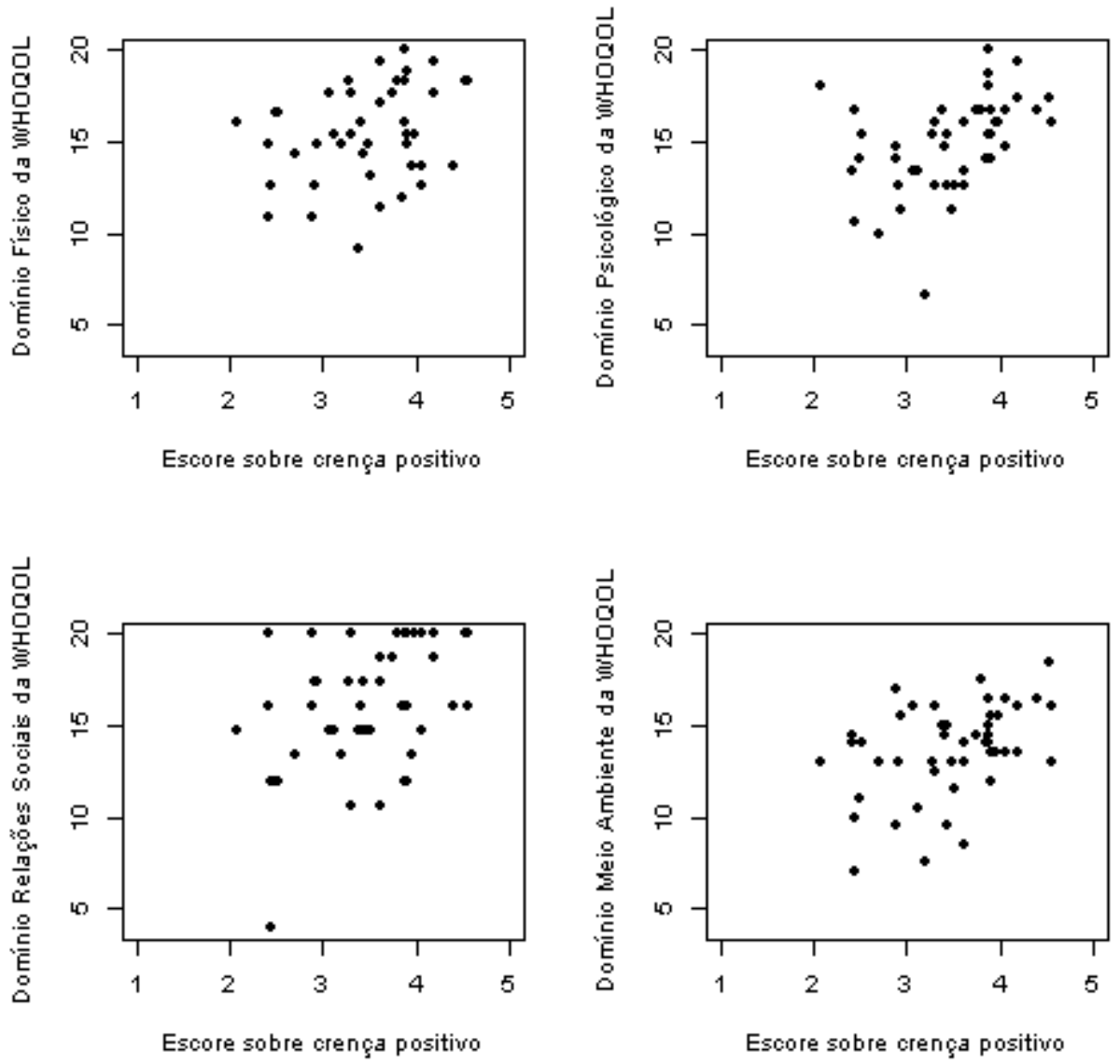

Gráfico 7 - Correlação entre WHOQOL - Breve X CRE positivo

3.9 - Análise das variáveis: idade, estado civil, profissão, primeira cirurgia e já ter realizado outras cirurgias, tempo de internação, conhecimento sobre a data da cirurgia e grau de escolaridade de modo independente para o Instrumento CRE - Coping Religioso/Espiritual

3.9.1 Analise das Estratégias de Coping Religioso/Espiritual positivo e negativo x idade

Como a amostra apresentou uma grande disparidade em relação a faixa etária onde a idade da mãe variou de 16 a 54 anos, foi utilizado o Teste F da ANOVA para avaliação de acordo com a distribuição da faixa etária em relação a utilização do CRE positivo e CRE negativo. Os resultados demonstram que em relação ao CRE positivo a maior média compreende a faixa etária de mães acima de 36 anos (3,98\%) (Tabela 17). Quanto ao CRE negativo o resultado não foi significativo (Tabela 18). 
Tabela 17 - Descrição das médias dos escores de coping religioso/espiritual positivo por faixa etária Teste F da ANOVA

\begin{tabular}{|c|c|c|c|c|c|c|c|c|}
\hline \multirow{2}{*}{ Faixa Etária } & \multirow{2}{*}{$\mathrm{N}$} & \multirow{2}{*}{ Mínimo } & \multirow{2}{*}{ Máximo } & \multirow{2}{*}{ Média } & \multirow{2}{*}{$\begin{array}{l}\text { Desvio } \\
\text { padrão }\end{array}$} & \multicolumn{2}{|c|}{ IC para média (95\%) } & \multirow{2}{*}{$\begin{array}{l}\text { Valor de } \\
\mathrm{p}\end{array}$} \\
\hline & & & & & & Inf & Sup & \\
\hline Total & 48 & 2,09 & 4,56 & 3,48 & 0,63 & 3,29 & 3,66 & \multirow{4}{*}{$\mathbf{0 , 0 2 0}$} \\
\hline 16 a 26 anos & 15 & 2,09 & 4,56 & 3,27 & 0,66 & 2,90 & 3,63 & \\
\hline De 26 a 36 anos & 24 & 2,41 & 4,56 & 3,42 & 0,62 & 3,16 & 3,68 & \\
\hline Mais de 36 anos & 9 & 3,62 & 4,53 & 3,98 & 0,33 & 3,73 & 4,23 & \\
\hline
\end{tabular}

Tabela 18 - Descrição das médias dos escores de coping religioso/espiritual negativo por faixa etária Teste F da ANOVA

\begin{tabular}{|c|c|c|c|c|c|c|c|c|}
\hline \multirow{2}{*}{ Domínios } & \multirow{2}{*}{$\mathrm{N}$} & \multirow{2}{*}{ Mínimo } & \multirow{2}{*}{ Máximo } & \multirow{2}{*}{ Média } & \multirow{2}{*}{$\begin{array}{l}\text { Desvio } \\
\text { padrão }\end{array}$} & \multicolumn{2}{|c|}{ IC para média (95\%) } & \multirow{2}{*}{$\begin{array}{l}\text { Valor de } \\
\mathrm{p}\end{array}$} \\
\hline & & & & & & Inf & Sup & \\
\hline Total & 48 & 1,13 & 3,33 & 1,84 & 0,49 & 1,70 & 1,98 & \multirow{4}{*}{0,589} \\
\hline 16 a 26 anos & 15 & 1,20 & 3,33 & 1,92 & 0,60 & 1,59 & 2,26 & \\
\hline De 26 a 36 anos & 24 & 1,13 & 3,07 & $\mathbf{1 , 8 3}$ & 0,48 & 1,63 & 2,04 & \\
\hline Mais de 36 anos & 9 & 1,33 & 2,07 & 1,71 & 0,25 & 1,52 & 1,90 & \\
\hline
\end{tabular}

Esses dados demonstram que as mães acima de 36 anos utilizam muito mais o CRE positivo $(3,98 \%)$ em relação as mães de faixa etária inferior. No caso do CRE negativo não houve diferença significativa entre as faixas etárias.

3.9.2 Analise das Estratégias de Coping Religioso/Espiritual positivo e negativo x estado civil

Em relação ao estado civil 34 mães $(70,8 \%)$ declararam morar com um companheiro ou serem casadas enquanto $14(29,2 \%)$ não possuem companheiro. Analisando a variável ter ou não companheiro em relação a utilização de CRE positivo (Tabela 19) e a utilização de CRE negativo (Tabela 20), não houve diferença entre as duas variáveis,ou seja, ter ou não companheiro ou estar ou não casadas não influenciam na utilização de uma ou outra estratégia de CRE. 
Tabela 19 - Descrição das médias dos escores de coping religioso/espiritual positivo e estado civil - Teste F da ANOVA

\begin{tabular}{lccccccccc}
\hline Variável & Fator & N & MIN & MAX & MÉDIA & D.P. & IC_inf & IC_sup & Valor p \\
\hline & TOTAL & $\mathbf{4 8}$ & $\mathbf{2 , 0 8 8}$ & $\mathbf{4 , 5 5 9}$ & $\mathbf{3 , 4 7 5}$ & $\mathbf{0 , 6 3 2}$ & $\mathbf{3 , 2 9 1}$ & $\mathbf{3 , 6 5 9}$ & \\
\hline \multirow{2}{*}{ Estado civil } & Com companheiro & 34 & 2,088 & 4,559 & 3,520 & 0,668 & 3,287 & 3,753 & \multirow{2}{*}{0,454} \\
& Sem companheiro & 14 & 2,441 & 4,176 & 3,368 & 0,541 & 3,056 & 3,680 & \\
\hline
\end{tabular}

Tabela 20 - Descrição das médias dos escores de coping religioso/espiritual negativo e estado civil -Teste F da ANOVA

\begin{tabular}{llrrrrrrrr}
\hline Variável & Fator & N & MIN & MAX & MÉDIA & D,P, & IC_inf & IC_sup & Valor p \\
\hline & TOTAL & $\mathbf{4 8}$ & $\mathbf{1 , 1 3 3}$ & $\mathbf{3 , 3 3 3}$ & $\mathbf{1 , 8 3 9}$ & $\mathbf{0 , 4 8 6}$ & $\mathbf{1 , 6 9 8}$ & $\mathbf{1 , 9 8 0}$ & \\
\hline \multirow{2}{*}{ Estado civil } & com companheiro & 34 & 1,133 & 3,333 & 1,818 & 0,485 & 1,649 & 1,987 & \multirow{2}{*}{0,642} \\
& sem companheiro & 14 & 1,267 & 3,200 & 1,890 & 0,502 & 1,600 & 2,180 & \\
\hline
\end{tabular}

\subsubsection{Análise das estratégias de coping Religioso/Espiritual positivo e negativo x profissão}

Em relação a variável profissão e utilização de CRE positivo e negativo, consideramos no estudo mães que possuem profissão e na ocasião da coleta dos dados estavam trabalhando 25 $(52,1 \%)$, mães que tinham profissão mas não estavam trabalhando $23(47,9 \%)$ foram incluídas na categoria sem profissão. Tanto na utilização de CRE positivo (Tabela 21) quanto em relação ao CRE negativo (Tabela 22) não houve diferença entre as variáveis. Ter ou não profissão não foi significativo em relação a utilização de estratégias de CRE positivo ou negativo.

Tabela 21 - Descrição das médias dos escores de coping religioso/espiritual positivo e profissão - Teste F da ANOVA

\begin{tabular}{lcrrrrrrrr}
\hline Variável & Fator & N & MIN & MAX & MÉDIA & D.P. & IC_inf & IC_sup & Valor p \\
\hline & TOTAL & $\mathbf{4 8}$ & $\mathbf{2 , 0 8 8}$ & $\mathbf{4 , 5 5 9}$ & $\mathbf{3 , 4 7 5}$ & $\mathbf{0 , 6 3 2}$ & $\mathbf{3 , 2 9 1}$ & $\mathbf{3 , 6 5 9}$ & \\
\hline \multirow{2}{*}{ Profissão o } & Não & 23 & 2,088 & 4,559 & 3,537 & 0,671 & 3,247 & 3,827 & \multirow{2}{*}{0,523} \\
& Sim & 25 & 2,412 & 4,559 & 3,419 & 0,601 & 3,171 & 3,667 & \\
\hline
\end{tabular}


Tabela 22 - Descrição das médias dos escores de coping religioso/espiritual negativo e profissão - Teste $\mathrm{F}$ da ANOVA

\begin{tabular}{llrrrrrrrr}
\hline Variável & Fator & N & MIN & MAX & MÉDIA & D,P, & IC_inf & IC_sup & Valor p \\
\hline \multirow{2}{*}{ Profissão } & TOTAL & $\mathbf{4 8}$ & $\mathbf{1 , 1 3 3}$ & $\mathbf{3 , 3 3 3}$ & $\mathbf{1 , 8 3 9}$ & $\mathbf{0 , 4 8 6}$ & $\mathbf{1 , 6 9 8}$ & $\mathbf{1 , 9 8 0}$ & \\
& Não & 23 & 1,200 & 3,200 & 1,849 & 0,477 & 1,643 & 2,055 & \\
& Sim & 25 & 1,133 & 3,333 & 1,829 & 0,503 & 1,621 & 2,037 & \\
\hline
\end{tabular}

3.9.4 Analise das estratégias de coping religioso/espiritual positivo e negativo x primeira cirurgia e x pré-operatorio com cirurgias anteriores

Analisando as variáveis: ter realizado cirurgias anteriores e a primeira cirurgia com a utilização de CRE positivo e CRE negativo, houve diferença na utilização de CRE positivo $\mathrm{p}<$ 0,03 (Tabela 23). Em relação a utilização de CRE negativo (Tabela 24) não houve diferença.

Tabela 23 - Descrição das médias dos escores de coping religioso/espiritual positivo e primeira cirurgia $\mathrm{x}$ pré-operatórios com cirurgias anteriores - Teste F da ANOVA.

\begin{tabular}{ccccccccccc}
\hline Variável & Fator & N & MIN & MAX & MÉDIA & D.P. & IC_inf & IC_sup & Valor p \\
\hline & TOTAL & $\mathbf{4 8}$ & $\mathbf{2 , 0 8 8}$ & $\mathbf{4 , 5 5 9}$ & $\mathbf{3 , 4 7 5}$ & $\mathbf{0 , 6 3 2}$ & $\mathbf{3 , 2 9 1}$ & $\mathbf{3 , 6 5 9}$ & \\
\hline \multirow{2}{*}{$\begin{array}{c}\text { Já realizou } \\
\text { cirurgia }\end{array}$} & não & 29 & 2,088 & 4,529 & 3,317 & 0,635 & 3,075 & 3,559 & $\mathbf{0 , 0 3 1}$ \\
\hline
\end{tabular}

Tabela 24 - Descrição das médias dos escores de coping religioso/espiritual negativo e primeira cirurgia $\mathrm{x}$ pré-operatórios com cirurgias anteriores - Teste F da ANOVA.

\begin{tabular}{llrrrrrrrr}
\hline Variável & Fator & N & MIN & MAX & MÉDIA & D,P, & IC_inf & IC_sup & Valor p \\
\hline & TOTAL & $\mathbf{4 8}$ & $\mathbf{1 , 1 3 3}$ & $\mathbf{3 , 3 3 3}$ & $\mathbf{1 , 8 3 9}$ & $\mathbf{0 , 4 8 6}$ & $\mathbf{1 , 6 9 8}$ & $\mathbf{1 , 9 8 0}$ & \\
\hline \multirow{2}{*}{$\begin{array}{c}\text { Já realizou } \\
\text { cirurgia }\end{array}$} & não & 29 & 1,133 & 3,333 & 1,837 & 0,514 & 1,641 & 2,033 & \\
& Sim & 19 & 1,267 & 3,067 & 1,842 & 0,452 & 1,624 & 2,060 & 0,971 \\
\hline
\end{tabular}

Estes dados demonstram que tanto as mães que aguardavam o primeiro procedimento cirúrgico da criança $29(60,4 \%)$ quanto as mães que já haviam passado por essa experiência anteriormente $19(39,6 \%)$ utilizam estratégias de CRE positivo para enfrentar essa situação. 
3.9.5 Analise das estratégias de coping religioso/espiritual positivo e negativo $\mathrm{x}$ tempo de internação

Analisando o tempo de internação e a utilização de CRE positivo (Tabela 25) e a utilização de CRE negativo (Tabela 26) não houve diferença entre as variáveis, ou seja, o tempo de internação não interferiu na utilização de uma ou outra estratégia de CRE.

Tabela 25 - Descrição das médias dos escores de coping religioso/espiritual positivo e tempo de internação - Teste F da ANOVA

\begin{tabular}{llrrrrrrrr}
\hline Variável & Fator & N & MIN & MAX & MÉDIA & D.P. & IC_inf & IC_sup & Valor p \\
\hline & TOTAL & $\mathbf{4 8}$ & $\mathbf{2 , 0 8 8}$ & $\mathbf{4 , 5 5 9}$ & $\mathbf{3 , 4 7 5}$ & $\mathbf{0 , 6 3 2}$ & $\mathbf{3 , 2 9 1}$ & $\mathbf{3 , 6 5 9}$ & \\
\hline \multirow{3}{*}{ Internada } & 1 dia & 9 & 2,412 & 4,059 & 3,291 & 0,647 & 2,794 & 3,788 & \\
& 1 a 7 dias & 22 & 2,088 & 4,559 & 3,561 & 0,657 & 3,270 & 3,852 & 0,563 \\
& Mais de 8 dias & 17 & 2,412 & 4,559 & 3,462 & 0,606 & 3,150 & 3,774 & \\
\hline
\end{tabular}

Tabela 26 - Descrição das médias dos escores de coping religioso/espiritual negativo e tempo de internação - Teste F da ANOVA

\begin{tabular}{llrrrrrrrr}
\hline Variável & Fator & N & MIN & MAX & MÉDIA & D,P, & IC_inf & IC_sup & Valor p \\
\hline \multirow{3}{*}{ Internada } & TOTAL & $\mathbf{4 8}$ & $\mathbf{1 , 1 3 3}$ & $\mathbf{3 , 3 3 3}$ & $\mathbf{1 , 8 3 9}$ & $\mathbf{0 , 4 8 6}$ & $\mathbf{1 , 6 9 8}$ & $\mathbf{1 , 9 8 0}$ & \\
& 1 dia & 9 & 1,200 & 2,000 & 1,667 & 0,254 & 1,472 & 1,862 & \\
& 1 a 7 dias & 22 & 1,333 & 3,067 & 1,876 & 0,454 & 1,675 & 2,077 & 0,508 \\
& Mais de 8 dias & 17 & 1,133 & 3,333 & 1,882 & 0,608 & 1,569 & 2,195 & \\
\hline
\end{tabular}

3.9.6 Analise das estratégias de coping religioso/espiritual positivo e negativo $\mathrm{x}$ conhecimento sobre a data da cirurgia

Algumas mães tinham conhecimento sobre a data da cirurgia enquanto outras não ou aguardavam algum resultado de exame. Analisando essas duas variáveis: ter conhecimento sobre a data ou não em relação ao CRE positivo (Tabela 27) e o CRE negativo (Tabela 28) não houve diferença. O fato de ter ou não conhecimento sobre a data da cirurgia não influenciou na utilização de uma ou outra estratégia de CRE. 
Tabela 27 - Descrição das médias dos escores de coping religioso/espiritual positivo e conhecimento sobre a data da cirurgia - Teste F da ANOVA

\begin{tabular}{clrrrrrrrr}
\hline Variável & Fator & N & MIN & MAX & MÉDIA & D.P. & IC_inf & IC_sup & Valor p \\
\hline & TOTAL & $\mathbf{4 8}$ & $\mathbf{2 , 0 8 8}$ & $\mathbf{4 , 5 5 9}$ & $\mathbf{3 , 4 7 5}$ & $\mathbf{0 , 6 3 2}$ & $\mathbf{3 , 2 9 1}$ & $\mathbf{3 , 6 5 9}$ & \\
\hline $\begin{array}{c}\text { Sabe } \\
\text { previsão da } \\
\text { cirurgia }\end{array}$ & Não sabe & 30 & 2,088 & 4,559 & 3,427 & 0,644 & 3,187 & 3,667 & \\
& Sabe & 18 & 2,412 & 4,559 & 3,556 & 0,620 & 3,248 & 3,864 & 0,502 \\
\hline
\end{tabular}

Tabela 28 - Descrição das médias dos escores de coping religioso/espiritual negativo e conhecimento sobre a data da cirurgia - Teste F da ANOVA

\begin{tabular}{clrrrrrrrr}
\hline Variável & Fator & N & MIN & MAX & MÉDIA & D,P, & IC_inf & IC_sup & Valor p \\
\hline & TOTAL & $\mathbf{4 8}$ & $\mathbf{1 , 1 3 3}$ & $\mathbf{3 , 3 3 3}$ & $\mathbf{1 , 8 3 9}$ & $\mathbf{0 , 4 8 6}$ & $\mathbf{1 , 6 9 8}$ & $\mathbf{1 , 9 8 0}$ & \\
\hline $\begin{array}{c}\text { Sabe } \\
\text { previsão da } \\
\text { cirurgia }\end{array}$ & Não sabe & 30 & 1,133 & 3,200 & 1,818 & 0,475 & 1,641 & 1,995 & \\
& Sabe & 18 & 1,267 & 3,333 & 1,874 & 0,514 & 1,618 & 2,130 & 0,702 \\
\hline
\end{tabular}

3.9.7 Analise das estratégias de coping religioso/espiritual positivo e negativo $\mathrm{x}$ grau de escolaridade

Em relação ao grau de escolaridade das mães e o uso de CRE positivo (Tabela 29) e o uso de CRE negativo (Tabela 30) não houve diferença entre as variáveis. O grau de escolaridade não influenciou na utilização de uma ou outra estratégia de CRE.

Tabela 29 - Descrição das médias dos escores de coping religioso/espiritual positivo e grau de escolaridade - Teste F da ANOVA

\begin{tabular}{clrrrrrrrr}
\hline Variável & Fator & N & MIN & MAX & MÉDIA & D.P. & IC_inf & IC_sup & Valor p \\
\hline & TOTAL & $\mathbf{4 8}$ & $\mathbf{2 , 0 8 8}$ & $\mathbf{4 , 5 5 9}$ & $\mathbf{3 , 4 7 5}$ & $\mathbf{0 , 6 3 2}$ & $\mathbf{3 , 2 9 1}$ & $\mathbf{3 , 6 5 9}$ & \\
\hline $\begin{array}{c}\text { Grau de } \\
\begin{array}{c}\text { escolaridade } \\
\text { da mãe }\end{array}\end{array}$ & Até fundamental & 21 & 2,412 & 4,559 & 3,653 & 0,578 & 3,390 & 3,916 & \\
& ensino médio & 27 & 2,088 & 4,559 & 3,338 & 0,647 & 3,082 & 3,594 & \\
\hline
\end{tabular}


Tabela 30 - Descrição das médias dos escores de coping religioso/espiritual negativo e grau de escolaridade - Teste F da ANOVA

\begin{tabular}{clrrrrrrrr}
\hline Variável & Fator & N & MIN & MAX & MÉDIA & D,P, & IC_inf & IC_sup & Valor p \\
\hline & TOTAL & $\mathbf{4 8}$ & $\mathbf{1 , 1 3 3}$ & $\mathbf{3 , 3 3 3}$ & $\mathbf{1 , 8 3 9}$ & $\mathbf{0 , 4 8 6}$ & $\mathbf{1 , 6 9 8}$ & $\mathbf{1 , 9 8 0}$ & \\
\hline $\begin{array}{c}\text { Grau de } \\
\begin{array}{c}\text { escolaridade } \\
\text { da mãe }\end{array}\end{array}$ & Até fundamental & 21 & 1,333 & 3,333 & 1,962 & 0,542 & 1,715 & 2,209 & \\
& ensino médio & 27 & 1,133 & 3,200 & 1,743 & 0,423 & 1,576 & 1,910 & 0,123 \\
\hline
\end{tabular}

3.9.7.1 Análise da interação entre CRE positivo x idade da mães x já ter realizado cirurgias anteriores

O gráfico 8 descreve a interação entre CRE positivo, faixa etária e já ter ou não realizado outras cirurgias. Através desta interação entre as variáveis observamos que as mães quais os filhos já haviam realizado procedimento cirúrgico anterior utilizavam mais o CRE positivo em relação as mães que estavam passando pela primeira vez por essa experiência. Em relação a faixa etária as mães acima de 36 anos obtiveram os escores mais altos em relação as outras faixas quanto a utilização de CRE positivo. 


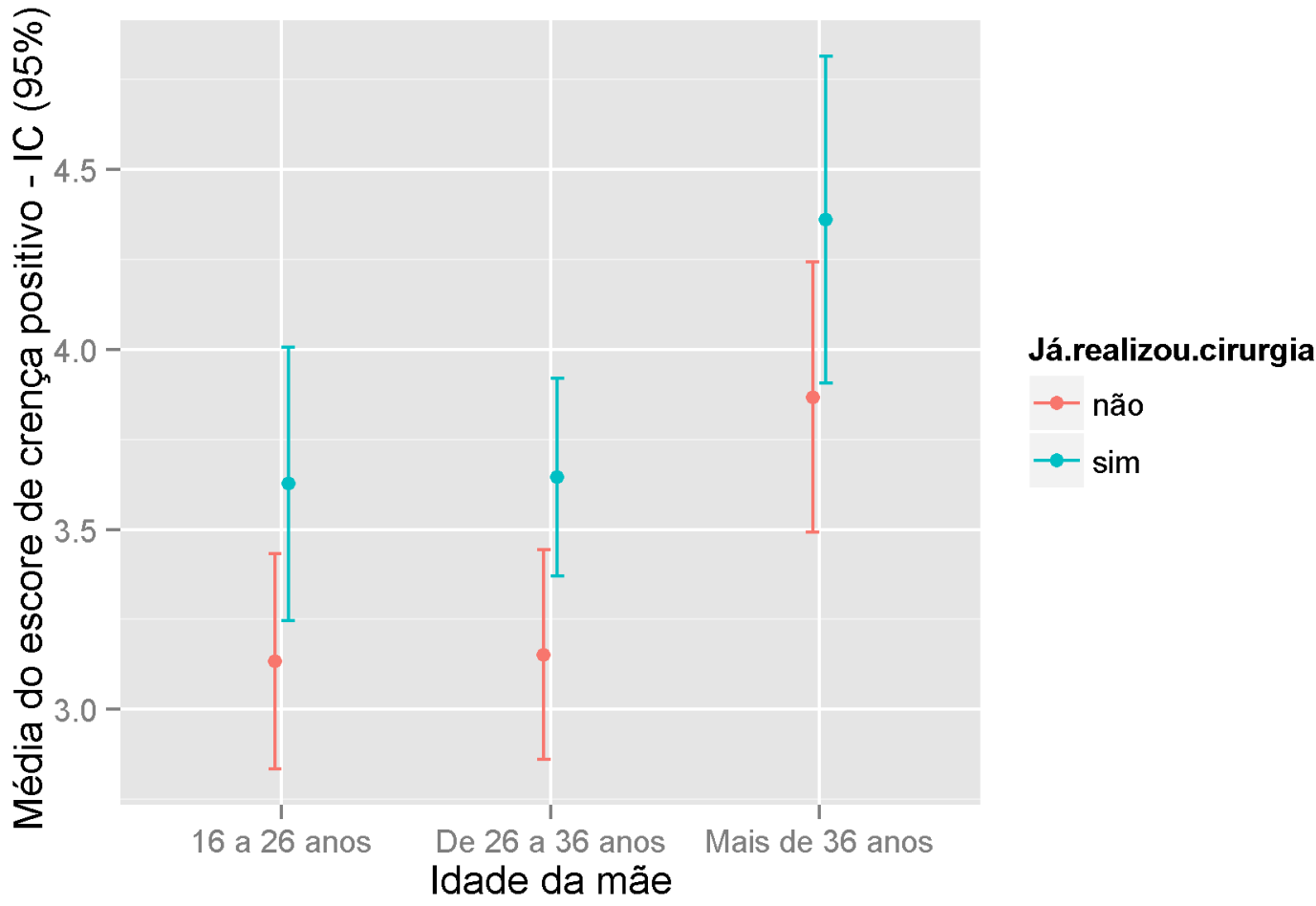

Gráfico 8 - Interação entre CRE positivo x faixa etária x já tem realizado outras cirurgias

Esses dados demonstram que tanto as mães que já tinham passado pela experiência de cirurgia ou cirurgias anteriores quanto as que estavam pela primeira vez vivendo essa experiência utilizavam significativamente o CRE positivo, porém as mães acima de 36 anos e que já haviam passado pela experiência de cirurgia anterior obtiveram média dos escores maiores em relação a utilização de CRE positivo em comparação as mães de faixa etária inferior e que estavam passando por essa experiência pela primeira vez. 
3.10 - Análise das variáveis: idade, estado civil, profissão, primeira cirurgia e já ter realizado outras cirurgias, tempo de internação, conhecimento sobre a data da cirurgia e grau de escolaridade de modo independente para o Instrumento WHOQOL - Breve

3.10.1 Analise das variáveis no Domínio 1- Físico

Analisando as variáveis idade, estado civil, profissão, ter realizado ou não cirurgias anteriores, tempo de internação, ter conhecimento ou não sobre a data da cirurgia e grau de escolaridade em relação ao domínio 1 (físico) que compõe o instrumento não houve diferença

Tabela 31 - Descrição do escore de QV (Domínio 1 - físico) e teste F da ANOVA para comparação de médias

\begin{tabular}{|c|c|c|c|c|c|c|c|c|c|}
\hline Variável & Fator & $\mathrm{N}$ & MIN & MAX & MÉDIA & D.P. & IC_inf & IC_sup & Valor $\mathrm{p}$ \\
\hline & TOTAL & 48 & 9,143 & 20,000 & 15,405 & 2,657 & 14,633 & 16,177 & \\
\hline \multirow{3}{*}{ Idade da mãe } & 16 a 25 anos & 15 & 10,857 & 19,429 & 15,390 & 2,514 & 13,998 & 16,782 & \multirow{3}{*}{0,274} \\
\hline & De 26 a 35 anos & 24 & 9,143 & 19,429 & 14,952 & 2,705 & 13,810 & 16,094 & \\
\hline & Mais de 36 anos & 9 & 11,429 & 20,000 & 16,635 & 2,656 & 14,593 & 18,677 & \\
\hline \multirow{2}{*}{ Estado civil } & com companheiro & 34 & 9,143 & 18,857 & 15,311 & 2,694 & 14,371 & 16,251 & \multirow{2}{*}{0,707} \\
\hline & sem companheiro & 14 & 10,857 & 20,000 & 15,633 & 2,648 & 14,104 & 17,162 & \\
\hline \multirow{2}{*}{ Profissão } & Não & 23 & 10,857 & 19,429 & 15,776 & 2,417 & 14,731 & 16,821 & \multirow{2}{*}{0,358} \\
\hline & Sim & 25 & 9,143 & 20,000 & 15,063 & 2,866 & 13,880 & 16,246 & \\
\hline \multirow{2}{*}{$\begin{array}{c}\text { Já realizou } \\
\text { cirurgia }\end{array}$} & Não & 29 & 10,857 & 19,429 & 15,172 & 2,437 & 14,245 & 16,099 & \multirow{2}{*}{0,460} \\
\hline & Sim & 19 & 9,143 & 20,000 & 15,759 & 2,995 & 14,315 & 17,203 & \\
\hline \multirow{3}{*}{ Internada } & $1 \mathrm{dia}$ & 9 & 12,571 & 16,571 & 14,921 & 1,260 & 13,952 & 15,890 & \multirow{3}{*}{0,838} \\
\hline & 1 a 7 dias & 22 & 9,143 & 20,000 & 15,506 & 2,921 & 14,211 & 16,801 & \\
\hline & Mais de 8 dias & 17 & 10,857 & 19,429 & 15,529 & 2,929 & 14,023 & 17,035 & \\
\hline \multirow{2}{*}{$\begin{array}{l}\text { Sabe previsão } \\
\text { da cirurgia }\end{array}$} & Não sabe & 30 & 11,429 & 18,857 & 15,505 & 2,023 & 14,750 & 16,260 & \multirow{2}{*}{0,740} \\
\hline & Sabe & 18 & 9,143 & 20,000 & 15,238 & 3,533 & 13,481 & 16,995 & \\
\hline \multirow{2}{*}{$\begin{array}{c}\text { Grau de } \\
\text { escolaridade } \\
\text { da mãe }\end{array}$} & Até fundamental & 21 & 10,857 & 20,000 & 15,701 & 2,803 & 14,425 & 16,977 & \multirow{2}{*}{0,502} \\
\hline & ensino médio & 27 & 9,143 & 19,429 & 15,175 & 2,567 & 14,160 & 16,190 & \\
\hline
\end{tabular}




\subsubsection{Análise das variáveis no Domínio 2 - Psicológico}

Analisando as variáveis idade, estado civil, profissão, ter realizado ou não cirurgias anteriores, tempo de internação, ter conhecimento ou não sobre a data da cirurgia e grau de escolaridade em relação ao domínio 2 (psicológico) que compõe o instrumento, houve diferença significativa $\mathrm{p}<0,05(0,031)$ em relação a idade das mães, ou seja, neste domínio a idade é uma variável significativa, conforme tabela abaixo.

Tabela 32 - Descrição do escore de QV (Domínio 2 - psicológico) e teste F da ANOVA para comparação de médias

\begin{tabular}{|c|c|c|c|c|c|c|c|c|c|}
\hline Variável & Fator & $\mathrm{N}$ & MIN & MAX & MÉDIA & $\mathrm{D}, \mathrm{P}$ & IC_inf & IC_sup & Valor $\mathrm{p}$ \\
\hline & TOTAL & 48 & 6,667 & 20,000 & 14,861 & 2,513 & 14,131 & 15,591 & \\
\hline \multirow{3}{*}{ Idade da mãe } & 16 a 25 anos & 15 & 10,667 & 18,667 & 14,311 & 2,252 & 13,064 & 15,558 & \multirow{3}{*}{$\mathbf{0 , 0 3 1}$} \\
\hline & De 26 a 35 anos & 24 & 6,667 & 19,333 & 14,472 & 2,619 & 13,366 & 15,578 & \\
\hline & Mais de 36 anos & 9 & 13,333 & 20,000 & 16,815 & 1,788 & 15,441 & 18,189 & \\
\hline \multirow{2}{*}{ Estado civil } & com companheiro & 34 & 10,000 & 18,667 & 15,137 & 2,034 & 14,427 & 15,847 & \multirow{2}{*}{0,240} \\
\hline & sem companheiro & 14 & 6,667 & 20,000 & 14,190 & 3,414 & 12,219 & 16,161 & \\
\hline \multirow{2}{*}{ Profissão } & não & 23 & 10,000 & 18,000 & 14,870 & 2,150 & 13,940 & 15,800 & \multirow{2}{*}{0,982} \\
\hline & $\operatorname{sim}$ & 25 & 6,667 & 20,000 & 14,853 & 2,851 & 13,676 & 16,030 & \\
\hline \multirow{2}{*}{$\begin{array}{c}\text { Já realizou } \\
\text { cirurgia }\end{array}$} & não & 29 & 6,667 & 18,000 & 14,391 & 2,401 & 13,478 & 15,304 & \multirow{2}{*}{0,110} \\
\hline & $\operatorname{sim}$ & 19 & 10,000 & 20,000 & 15,579 & 2,574 & 14,338 & 16,820 & \\
\hline \multirow{3}{*}{ Internada } & $1 \mathrm{dia}$ & 9 & 10,000 & 16,667 & 13,704 & 2,031 & 12,143 & 15,265 & \multirow{3}{*}{0,123} \\
\hline & 1 a 7 dias & 22 & 10,667 & 20,000 & 15,606 & 2,135 & 14,659 & 16,553 & \\
\hline & Mais de 8 dias & 17 & 6,667 & 19,333 & 14,510 & 2,977 & 12,979 & 16,041 & \\
\hline \multirow{2}{*}{$\begin{array}{l}\text { Sabe previsão } \\
\text { da cirurgia }\end{array}$} & Não sabe & 30 & 6,667 & 18,667 & 14,444 & 2,663 & 13,450 & 15,438 & \multirow{2}{*}{0,140} \\
\hline & Sabe & 18 & 12,667 & 20,000 & 15,556 & 2,133 & 14,495 & 16,617 & \\
\hline \multirow{2}{*}{$\begin{array}{c}\text { Grau de } \\
\text { escolaridade } \\
\text { da mãe }\end{array}$} & Até fundamental & 21 & 6,667 & 20,000 & 14,730 & 2,988 & 13,370 & 16,090 & \multirow[t]{2}{*}{0,754} \\
\hline & ensino médio & 27 & 10,000 & 19,333 & 14,963 & 2,127 & 14,122 & 15,804 & \\
\hline
\end{tabular}


3.10.2.1 Análise da interação entre o Domínio 2 (Psicológico) x idade da mães

A idade das mães conforme análise descrita na tabela 32 é uma variável significativa, vê-se que mães com mais de 36 anos possuem média 2,3 pontos maior no domínio psicológico comparada com as mães mais novas, ou seja, quanto maior a faixa etária maior a média obtida neste domínio (Gráfico 9).

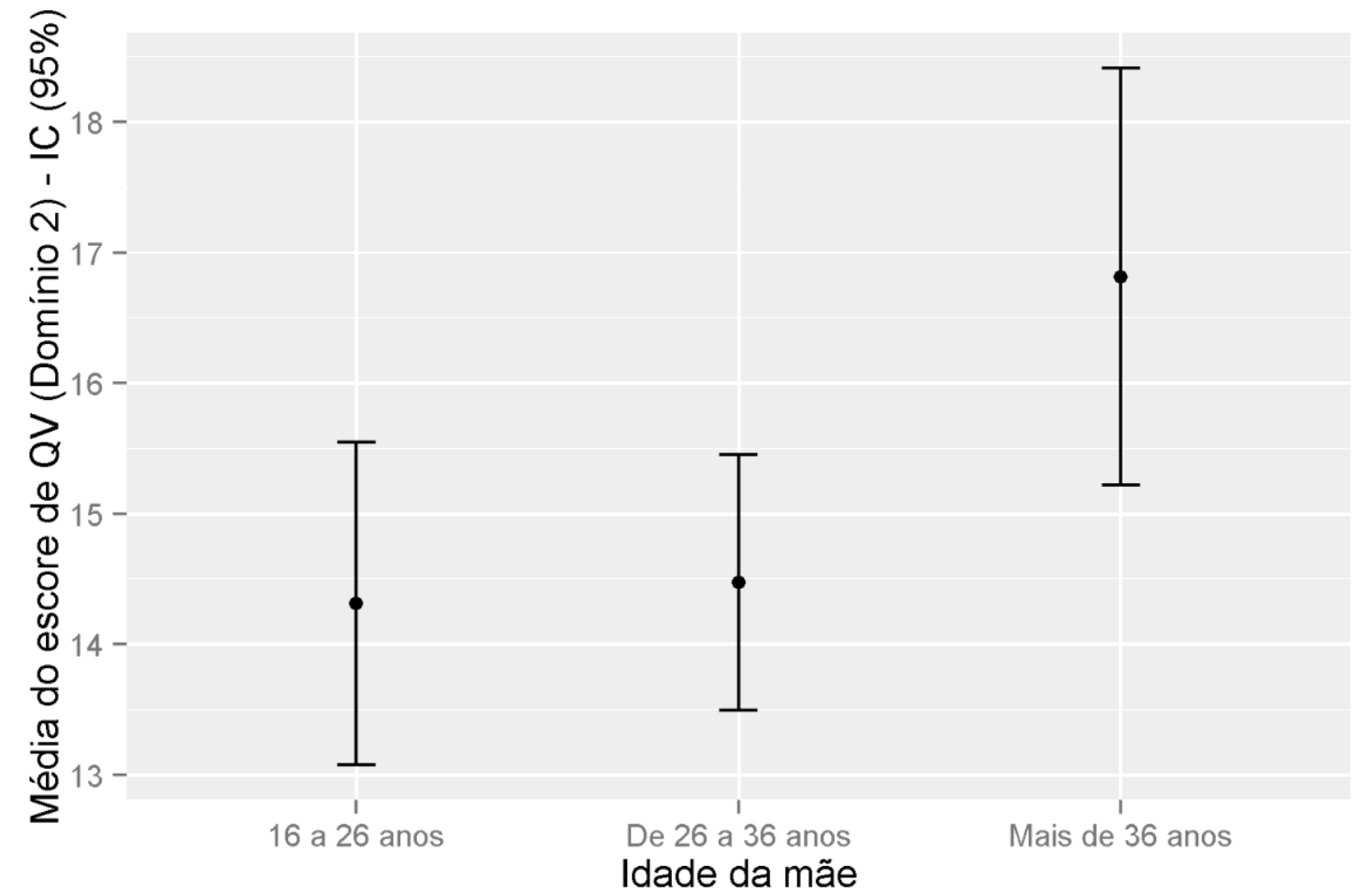

Gráfico 9 - Médias de QV (Domínio 2 - Psicológico) x faixa etária

3.10.3 Analise das variáveis no Domínio 3 - Relações Sociais

Analisando as variáveis idade, estado civil, profissão, ter realizado ou não cirurgias anteriores, tempo de internação, ter conhecimento ou não sobre a data da cirurgia e grau de escolaridade em relação ao domínio 3 (Relações Sociais) que compõe o instrumento, houve diferença significativa $\mathrm{p}<0,05$ em relação as variáveis: estado civil $(0,045)$ e ter 
profissão/trabalhar $(0,031)$ das mães, ou seja, no domínio relações sociais essas variáveis são significativas, conforme tabela abaixo.

Tabela 33 - Descrição do escore de QV (Domínio 3 - relações sociais) e teste F da ANOVA para comparação de médias univariado

\begin{tabular}{|c|c|c|c|c|c|c|c|c|c|}
\hline Variável & Fator & $\mathrm{N}$ & MIN & MAX & MÉDIA & $\mathrm{D}, \mathrm{P}$, & IC_inf & IC_sup & Valor $\mathrm{p}$ \\
\hline & TOTAL & 48 & 4,000 & 20,000 & 16,111 & 3,433 & 15,114 & 17,108 & \\
\hline \multirow{3}{*}{ Idade da mãe } & 16 a 25 anos & 15 & 12,000 & 20,000 & 15,733 & 2,265 & 14,479 & 16,987 & \multirow{3}{*}{0,164} \\
\hline & De 26 a 35 anos & 24 & 4,000 & 20,000 & 15,611 & 3,961 & 13,938 & 17,284 & \\
\hline & Mais de 36 anos & 9 & 10,667 & 20,000 & 18,074 & 3,135 & 15,664 & 20,484 & \\
\hline \multirow{2}{*}{ Estado civil } & com companheiro & 34 & 10,667 & 20,000 & 16,745 & 2,994 & 15,700 & 17,790 & \multirow{2}{*}{0,045} \\
\hline & sem companheiro & 14 & 4,000 & 20,000 & 14,571 & 4,033 & 12,242 & 16,900 & \\
\hline \multirow{2}{*}{ Profissão } & não & 23 & 10,667 & 20,000 & 17,217 & 3,033 & 15,905 & 18,529 & \multirow{2}{*}{$\mathbf{0 , 0 3 1}$} \\
\hline & $\operatorname{sim}$ & 25 & 4,000 & 20,000 & 15,093 & 3,522 & 13,639 & 16,547 & \\
\hline \multirow{2}{*}{$\begin{array}{c}\text { Já realizou } \\
\text { cirurgia }\end{array}$} & não & 29 & 4,000 & 20,000 & 15,448 & 3,729 & 14,030 & 16,866 & \multirow{2}{*}{0,099} \\
\hline & $\operatorname{sim}$ & 19 & 12,000 & 20,000 & 17,123 & 2,713 & 15,815 & 18,431 & \\
\hline \multirow{3}{*}{ Internada } & $1 \mathrm{dia}$ & 9 & 12,000 & 20,000 & 15,704 & 2,731 & 13,605 & 17,803 & \multirow{3}{*}{0,730} \\
\hline & 1 a 7 dias & 22 & 12,000 & 20,000 & 16,545 & 2,870 & 15,273 & 17,817 & \\
\hline & Mais de 8 dias & 17 & 4,000 & 20,000 & 15,765 & 4,428 & 13,488 & 18,042 & \\
\hline \multirow{2}{*}{$\begin{array}{l}\text { Sabe previsão da } \\
\text { cirurgia }\end{array}$} & Não sabe & 30 & 12,000 & 20,000 & 16,044 & 2,678 & 15,044 & 17,044 & \multirow{2}{*}{0,864} \\
\hline & Sabe & 18 & 4,000 & 20,000 & 16,222 & 4,510 & 13,979 & 18,465 & \\
\hline \multirow{2}{*}{$\begin{array}{c}\text { Grau de } \\
\text { escolaridade da } \\
\text { mãe }\end{array}$} & Até fundamental & 21 & 10,667 & 20,000 & 16,952 & 3,215 & 15,489 & 18,415 & \multirow{2}{*}{0,136} \\
\hline & ensino médio & 27 & 4,000 & 20,000 & 15,457 & 3,513 & 14,067 & 16,847 & \\
\hline
\end{tabular}

3.10.3.1 Análise da interação entre o Domínio 3 (Relações Sociais) x profissão

Em relação a variável profissão que neste estudo considerou não somente o fato de ter profissão como estar trabalhando, conforme análise descrita na tabela 33 é uma variável significativa, ou seja, as mães que não trabalham ou não tem profissão obtiveram as médias dos escores mais altos em relação as que trabalham.

Ajustou-se, então, um modelo de regressão linear considerando essas duas variáveis para explicar a variação do escore do Domínio 3. Constatou-se colinearidade entre as variáveis explicativas, viu-se que das mulheres que trabalhavam. $60 \%$ tinham companheiro, já as que não trabalhavam, $82 \%$ tinham companheiro. 
O modelo ajustado admitiu apenas profissão como variável suficiente para explicar a média do Domínio (Gráfico 10). Mulheres que não trabalham aumentam em média 2,2 pontos o escore.

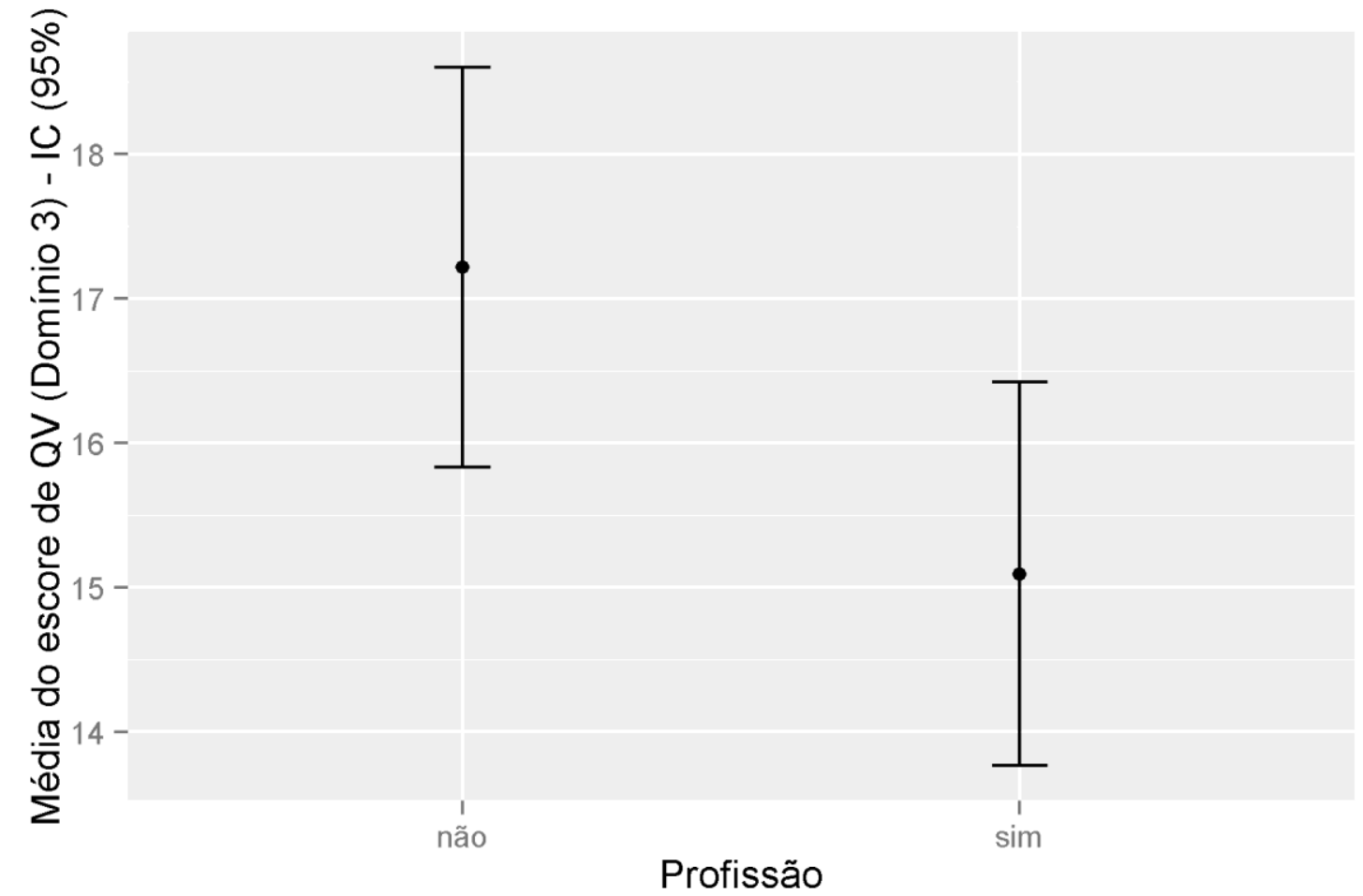

Gráfico 10- Interação entre QV (Domínio 3- Relações Sociais) x profissão

Esses dados demonstram que as mães que não tinham profissão ou não trabalhavam (82\% tinham companheiro) obtiveram média superior as mães que trabalhavam e não tinham companheiro $60 \%$ nessa amostra.

3.10.4 Analise das variáveis no Domínio 4 - Meio Ambiente

Analisando as variáveis idade, estado civil, profissão, ter realizado ou não cirurgias anteriores, tempo de internação, ter conhecimento ou não sobre a data da cirurgia e grau de escolaridade em relação ao domínio 4 (Meio Ambiente) que compõe o instrumento, houve diferença significativa $\mathrm{p}<0,05$ em relação a variável: estado civil $(0,002)$, conforme tabela abaixo. 
Tabela 34 - Descrição do escore de QV (Domínio 4 - meio ambiente) e teste F da ANOVA para comparação de médias

\begin{tabular}{|c|c|c|c|c|c|c|c|c|c|}
\hline Variável & Fator & $\mathrm{N}$ & MIN & MAX & MÉDIA & $\mathrm{D}, \mathrm{P}$, & IC_inf & IC_sup & Valor $\mathrm{p}$ \\
\hline & TOTAL & 48 & 7,000 & 18,500 & 13,688 & 2,561 & 12,944 & 14,432 & \\
\hline \multirow{3}{*}{ Idade da mãe } & 16 a 25 anos & 15 & 7,000 & 16,500 & 12,700 & 2,555 & 11,285 & 14,115 & \multirow{3}{*}{0,152} \\
\hline & De 26 a 35 anos & 24 & 7,500 & 17,500 & 13,938 & 2,383 & 12,932 & 14,944 & \\
\hline & Mais de 36 anos & 9 & 8,500 & 18,500 & 14,667 & 2,773 & 12,535 & 16,799 & \\
\hline \multirow{2}{*}{ Estado civil } & com companheiro & 34 & 7,000 & 18,500 & 14,412 & 2,324 & 13,601 & 15,223 & \multirow{2}{*}{0,002} \\
\hline & sem companheiro & 14 & 7,500 & 15,500 & 11,929 & 2,303 & 10,599 & 13,259 & \\
\hline \multirow{2}{*}{ Profissão } & Não & 23 & 8,500 & 18,500 & 14,043 & 2,056 & 13,154 & 14,932 & \multirow{2}{*}{0,361} \\
\hline & Sim & 25 & 7,000 & 17,500 & 13,360 & 2,956 & 12,140 & 14,580 & \\
\hline \multirow{2}{*}{$\begin{array}{c}\text { Já realizou } \\
\text { cirurgia }\end{array}$} & Não & 29 & 7,000 & 18,500 & 13,138 & 3,003 & 11,996 & 14,280 & \multirow{2}{*}{0,066} \\
\hline & Sim & 19 & 13,000 & 17,500 & 14,526 & 1,369 & 13,866 & 15,186 & \\
\hline \multirow{3}{*}{ Internada } & 1 dia & 9 & 10,500 & 16,500 & 13,333 & 1,803 & 11,947 & 14,719 & \multirow{3}{*}{0,680} \\
\hline & 1 a 7 dias & 22 & 7,000 & 18,500 & 14,045 & 2,886 & 12,765 & 15,325 & \\
\hline & Mais de 8 dias & 17 & 7,500 & 16,000 & 13,412 & 2,526 & 12,113 & 14,711 & \\
\hline \multirow{2}{*}{$\begin{array}{l}\text { Sabe previsão } \\
\text { da cirurgia }\end{array}$} & Não sabe & 30 & 7,000 & 16,500 & 13,400 & 2,650 & 12,410 & 14,390 & \multirow{2}{*}{0,321} \\
\hline & Sabe & 18 & 9,500 & 18,500 & 14,167 & 2,401 & 12,973 & 15,361 & \\
\hline \multirow{2}{*}{$\begin{array}{c}\text { Grau de } \\
\text { escolaridade } \\
\text { da mãe }\end{array}$} & Até fundamental & 21 & 7,000 & 18,500 & 13,810 & 2,998 & 12,445 & 15,175 & \multirow{2}{*}{0,774} \\
\hline & ensino médio & 27 & 8,500 & 17,000 & 13,593 & 2,219 & 12,715 & 14,471 & \\
\hline
\end{tabular}

3.10.4.1 Análise da interação entre o Domínio 4 (Meio Ambiente) x estado civil

A variável estado civil, conforme análise descrita na tabela 34 é uma variável significativa, ou seja, as mães que declararam ter um companheiro obtiveram as médias dos escores mais altos em relação as que são solteiras, viúvas ou separadas (Gráfico 11). 


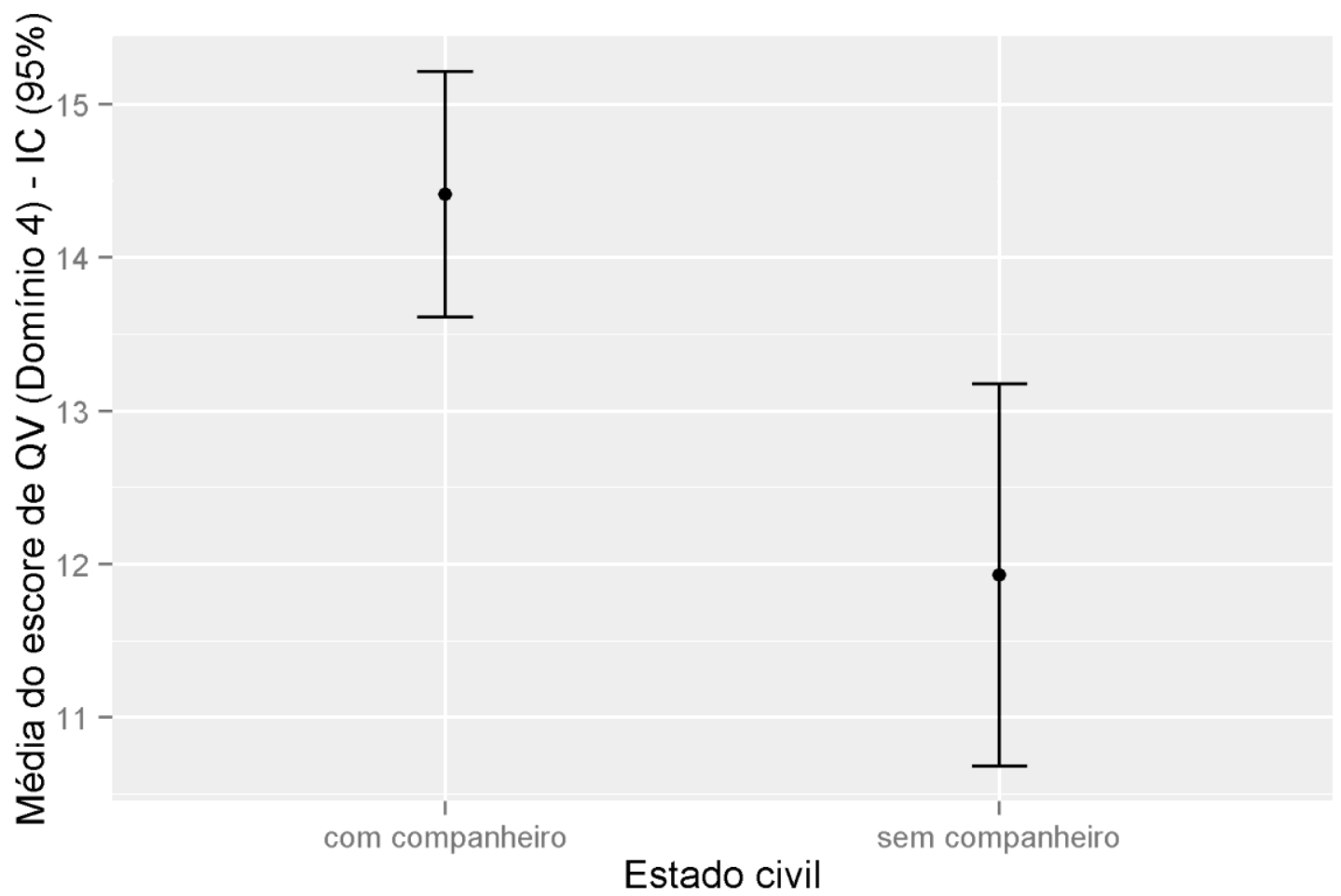

Gráfico 11- Interação entre QV (Domínio 4- Meio Ambiente) x estado civil 


\section{Discussão}

A utilização da espiritualidade e da religiosidade como estratégia de enfrentamento em pacientes tem sido foco de estudos pelos pesquisadores nas mais diversas doenças além de se constituir um verdadeiro desafio para a ciência ${ }^{78}$, no entanto pouco tem sido estudado em relação aos cuidadores.

Este estudo avaliou a utilização do coping religioso/espiritual como estratégia de enfrentamento em mães de crianças portadoras de cardiopatia congênita e suas possíveis correlações com a qualidade de vida. Também foram avaliadas as variáveis: idade, estado civil, profissão, ter realizado cirurgia anterior, tempo de internação, saber sobre a data da cirurgia e grau de escolaridade nos domínios que compõem o instrumento de qualidade de vida WHOQOLbref e na utilização de estratégias de enfrentamento positivo e negativo do instrumento CRE (Coping Religioso Espiritual).

Foram avaliadas 48 mães de crianças portadoras de cardiopatia congênita que estavam internadas e que aguardavam procedimento cirúrgico. A maioria das mães $25(52,1 \%)$ declararam trabalhar e mais da metade $34(70,8 \%)$ tinham companheiro ou eram casadas.

Vinte e nove mães $(60,4 \%)$ aguardavam pela primeira vez a cirurgia do filho enquanto 19 $(39,6 \%)$ já haviam passado por algum procedimento cirúrgico anterior. Das crianças que haviam passado por algum procedimento cirúrgico anterior, $16(84,2 \%)$ foram realizados no Incor.

Em relação ao fato de saber sobre a data da cirurgia a maioria das mães $29(60,4 \%)$ não tinham informação alguma ou aguardavam resultado de exames.

Todas as crianças estavam internadas na Unidade de Cardiopatia Congênita, a maioria das mães $29(60,4 \%)$ não tinham conhecimento sobre a data da cirurgia e $39(81,3 \%)$ crianças já estavam a uma semana ou mais internadas (Tabela1). Conforme achados na literatura ${ }^{14,37,38,29}$. à espera pelo procedimento cirúrgico ou resultado dos exames, a internação assim como a permanência no hospital são fatores estressantes tanto para a criança e principalmente para os pais.

Quarenta e sete mães (98\%) afirmaram ter religião, a maioria $25(52,1 \%)$ sendo católicas. Apenas uma das mães afirmou não ter religião, mas sim acreditar em uma força superior, em um 
Criador, conforme demonstra a tabela 3. Todas as mães relataram que a sua religião possui alguma prática religiosa como: orar, jejuar, ir às missas ou cultos religiosos, entre outras. Destas mães $15(31,9 \%)$ realizam alguma dessas práticas diariamente, $15(31,9 \%)$ às vezes, atingindo a mesma média de frequiência apresentada no item anterior, 8 (17\%) freqüentemente, 7 (14,5\%) nunca e $3(6,3 \%)$ raramente. É importante salientar que neste item a mãe que afirmou não ter religião faz parte da porcentagem que compõe a categoria "freqüentemente", ao contrário de algumas mães que embora afirmaram ter religião compuseram a categoria "nunca". Esses dados demonstram que o fato de ter uma religião propriamente dita não significa ter alguma prática religiosa e o inverso também é verdadeiro quando a mãe que declarou não ter religião afirmou realizar alguma prática religiosa "frequentemente". As descrições das categorias estão na tabela 3.

Diante da descoberta do problema da criança 35 mães $(72,9 \%)$ declararam ter aumentado a sua prática religiosa após o diagnóstico do filho (Tabela 3).

Ainda em relação aos dados do questionário semi-estruturado as questões: "O que é Deus para a Sra.?" (Tabela 4), "De que maneira a Sra. acredita que a sua crença/religião ajudou ou não a enfrentar o problema com seu filho?" (Tabela 5) e "Baseado na sua experiência de que a crença/religião ajudou você a enfrentar estes problemas, que mensagem ou sugestão você daria a outras mães que se encontram nesta situação?" (Tabela 6) foram tratadas separadamente através da caracterização das freqüências de respostas.

Quando perguntadas sobre o significado de "Deus", 35 mães (73\%) responderam a palavra "tudo" (Tabela 4), dado este significativo em termos de freqüência, porém é necessário maior investigação deste constructo em futuras pesquisas, uma vez que nessa amostra não contemplou o estudo do seu significado.

Diante das questão relacionadas ao fato da crença/religião ter ajudado ou não a enfrentar a situação com filho de que maneira e qual a sugestão ou mensagem que essas mães dariam a outras que passam pela mesma situação, 25 mães $(52,1 \%)$ afirmaram que a crença/religião é a fonte de onde retiram força para enfrentar a situação (Tabela 5) e 36 mães (75\%) sugerem as outras mães que se encontram na mesma situação que busquem a Deus (Tabela 6), independente de terem ou não uma crença religiosa, pois é através de Deus que elas encontram sustentação para trilhar um novo caminho após o diagnóstico, conforme dados da literatura ${ }^{12}$. 
A qualidade de vida destas mães foi avaliada através do instrumento WHOQOL Abreviado, entre os quatro domínios que compõe: físico, psicológico, relações sociais e meio ambiente, a que obteve maior média foi o das relações sociais: 16,11 (dp=3,43), seguido do físico 15,40 (dp=2,66), psicológico 14,86 (dp=2,51) e o meio ambiente 13,69 (dp=2,56) (Tabela 8).

O domínio relações sociais é composto por três questões: Q20: "Quão satisfeito (a) vocêe está com suas relações pessoais (amigos, parentes, conhecidos, colegas)?, Q21: “Quão satisfeito (a) você está com sua vida sexual?”e Q22: “Quão satisfeito (a) você está com o apoio que você recebe de seus amigos?”, a que obteve maior média (56,2\%) foi a questão (Q22) (Tabela 9).

Diante da circunstância que estão vivendo com a criança, o apoio tanto dos amigos, quanto dos familiares, são muito importantes, levando em consideração que 39 (81.3\%) destas crianças estão internadas a uma semana ou mais (Tabela 1) e esse fato causa mudança na rotina da família que muitas vezes precisam de ajuda de seus familiares. Esses fatores geram desgaste tanto físico como psicológico tanto para a criança quanto para a família ${ }^{11}$. Os dados demonstram que neste domínio (relações sociais) as mães obtiveram a média de escores superior aos outros domínios o que indica estarem satisfeitas com o apoio que recebem dos amigos.

Em relação à auto-avaliação da qualidade de vida e percepção geral de saúde composta pelas questões: Q1: “como você avaliaria sua qualidade de vida?” e "quão satisfeito (a) você esta com a sua saúde", respectivamente 35 mães $(72,9 \%)$ consideram boa ou muito boa a sua qualidade de vida e 31 mães $(64,6 \%)$ estão satisfeitas ou muito satisfeitas com sua saúde (Tabela 9).

Analisando todas as questões do instrumento (Tabela 9), a questão que obteve a freqüência mais alta foi a Q26: “Com que freqüencia você tem sentimentos negativos tais como: mau humor, desespero, ansiedade, depressão?", 29 mães (60,4\%) declararam apresentar algumas vezes, 11 $(22,9 \%)$ frequentemente, $1(2,1 \%)$ muito freqüente e $5(10,4 \%)$ sempre, ou seja, 46 mães $(95,8 \%)$ declararam apresentar algum tipo de sentimento negativo tais como: mau humor, desespero, ansiedade, depressão. Esses dados demonstram que nesta amostra sentimentos negativos estão presentes e merecem uma investigação mais detalhada pois indicam sofrimento psíquico.

Para avaliar a estratégia de coping religioso/espiritual nesta amostra utilizamos a escala CRE. Esta escala pede primeiramente para que a pessoa descreva em poucas palavras a situação de maior estresse que vivenciou nos últimos três anos. Nesta amostra 31 mães $(64,6 \%)$ 
descreveram questões relacionadas à criança e 17 (35,4\%) descreveram outras situações (Tabela $11)$.

Conforme descrito na Tabela 11 as mães apontam como fatores geradores de estresse: o diagnóstico, a internação, a possibilidade ou constatação da necessidade da cirurgia assim como a possibilidade de transplante, a permanência na UTI além da piora do quadro clínico da criança. Estes dados confirmam os encontrados na literatura onde várias pesquisas apontam esses mesmos eventos descritos como estressores pelos cuidadores que lidam com enfermidade pediátrica ${ }^{32,14,}$ $37,34,29$

Analisando a média entre os fatores positivos e negativos (Tabela 12) separadamente que compõe o instrumento em questão, o fator P4 (positivo) - posição positiva frente a Deus obteve a maior média 4,71 ( $\mathrm{dp}=0,43)$. Este fator é composto pelas seguintes questões: Q2- procurei o amor e a proteção de Deus (apoio espiritual), Q6- procurei em Deus força, apoio e orientação (apoio espiritual), Q17- tentei lidar com meus sentimentos sem pedir a ajuda de Deus (autodirecionamento), Q30- confiei que Deus estava comigo (apoio espiritual), Q43- tentei lidar com a situação do meu jeito, sem a ajuda de Deus (autodirecionamento).

Os dados demonstram que as mães de crianças portadoras de cardiopatia congênita possuem um posicionamento positivo frente a Deus, ou seja, estas mães buscaram em Deus proteção, força, apoio e orientação

O fator P4: Posicionamento positivo frente a Deus é definido como: todo comportamento de coping religioso espiritual que expõe um posicionamento pessoal frente a Deus em relação à situação. Poderão manifestar-se através de estilos de CRE, estabelecimento de limites religiosos, busca de apoio em Deus, de uma maior conexão com Ele e/ou de reavaliações positivas através d'Ele. Revelam-se em atitudes como contar, colaborar, suplicar, se aproximar e/ou se apoiar em Deus, ou ainda em ações individuais independentes da ajuda de Deus. Cabe realçar que, quanto mais a pessoa faz estas últimas, menos realiza as primeiras ${ }^{5}$.

Em relação aos fatores negativos o que obteve maior média foi o fator N2 (negativo) posicionamento negativo frente a Deus obteve a maior média 2,51 (dp=1,14). As questões que compõem este fator são: Q3 - não fiz muito, apenas esperei que Deus resolvesse meus problemas por mim (delegação), Q22 - não tentei lidar com a situação, apenas esperei que Deus levasse minhas preocupações embora (delegação), Q41 - sabia que não poderia dar conta da situação, então apenas esperei que Deus assumisse o controle (delegação). 
Os dados da Tabela 12 demonstram que as mães das crianças com cardiopatia congênita obtiveram a maior média no fator N2, porém como a escala de resposta é invertida significa que essas mães possuem pouco posicionamento negativo frente a Deus, ou seja, no enfrentamento da situação elas buscam apoio em Deus e não delegam unicamente a Ele o controle da situação.

O fator N2: Posicionamento negativo frente a Deus é definido como: todo comportamento de coping religioso espiritual no qual a pessoa pede ou simplesmente espera que Deus tome o controle da situação e se responsabilize por resolvê-la, sem a sua participação individual. Pode expressar-se através do estilo de coping delegação religiosa passiva ou negativa, quando a prece tenciona a modificação da vontade divina ${ }^{5}$.

$\mathrm{Na}$ análise das médias entre os fatores: positivo, negativo e negativo (invertido), o que obteve a maior média foi o negativo invertido $4,16 \%(\mathrm{dp}=0,49)$ (Tabela 13). Isso significa que os escores que compõe este fator foram alto, ou seja, a maior freqüência de respostas foi entre 4 (um pouco) e 5 (nem um pouco) (Gráfico 3). Estes dados demonstram que estas mães apresentam pouco sentimento negativo ou nenhum frente a Deus.

O CRE total permitiu avaliar o total de CREs utilizados pelas mães, no entanto, para sabermos em que proporção estas mães utilizaram o CRE negativo em relação ao CRE positivo analisamos a Razão CREN/CREP. Nesta amostra podemos afirmar que houve um balanço positivo, ou seja, 1CREN: 2CREP, traduzidos numa Razão=0,50 (Gráfico 4) conforme sugerido por Panzini ${ }^{5}$.

A questão Q43: “Tentei lidar com a situação do meu jeito, sem ajuda de Deus” foi a que obteve maior média, esta é analisada invertida, o que significa que 47 mães (97,9\%) responderam que "nem um pouco" tentaram lidar com a situação sem a ajuda de Deus (Tabela 14).

Os instrumentos que avaliam tanto a qualidade de vida quanto o coping religioso espiritual foram avaliados através do Alpha de Cronbach.

O WHOQOL-breve obteve resultado acima de 0,50 considerado satisfatório ${ }^{79}$ para amostra (Tabela 7) em todos os domínios do instrumento.

Em relação ao instrumento CRE, a analise feita através do Alpha de Cronbach demonstrou que o único fator que não apresentou coeficiente satisfatório foi o fator N4 $(0,186)$ (Tabela 10).

O fator N4 significa: todo comportamento de coping religioso espiritual que revela sentimentos de insatisfação, desgosto ou mágoa com qualquer representante institucional, seja ele freqüentador, membro, representante ou líder da instituição religiosa, ou mesmo simbolizado pelo 
conjunto de crenças religiosas ou espirituais que a pessoa possui ${ }^{5}$. Panzini ${ }^{5}$ também encontrou baixo desempenho no mesmo fator numa amostra composta por 616 participantes.

Analisando as correlações dos domínios que compõem o instrumento WHOQOL-bref na amostra os dados demonstraram que o único domínio que apresentou correlação com os demais foi o domínio 4 (meio ambiente) com o domínio 3 (relações sociais) e o domínio 4 (meio ambiente) com o domínio 2 (relações sociais) (Gráfico 5).

A análise da correlação entre as dimensões da Escala CRE-breve através do Alpha de Cronbach na amostra demonstrou que todos os fatores da escala se correlacionam, o CRE Total $\mathrm{x}$ CRE Positivo e CRE Total x CRE negativo invertido (Gráfico 6).

Em relação às possíveis relações entre qualidade de vida e coping religioso espiritual, podemos afirmar que todos os domínios do instrumento WHOQOL-breve se correlacionam com o CRE positivo (Tabela 15, 16 e Gráfico 7), indicando assim que existe uma forte correlação entre coping religioso espiritual e qualidade de vida, conforme os dados da literatura ${ }^{43,59,60,64,65}$.

As variáveis: idade, estado civil, profissão, primeira cirurgia e já ter realizado outras cirurgias, tempo de internação, conhecimento sobre a data da cirurgia e grau de escolaridade foram analisadas de modo independente nos dois instrumentos.

A análise entre a variável idade e as estratégias de CRE apontou que apenas o CRE positivo $(\mathrm{p}=0,020)$ demonstrou correlação significativa $(\mathrm{p}<0,5)$ (Tabela 17). Os dados também apontam que mães acima de 36 anos obtiveram média maior 3,98 $(\mathrm{dp}=0,33)$ em relação às outras faixas.

A variável estar vivenciando o primeiro procedimento cirúrgico e já ter vivido esta experiência e a utilização de estratégias de CRE apontou correlação significativa $(\mathrm{p}<0,5)$ apenas na utilização de estratégias de $\mathrm{CRE}$ positivo ( $\mathrm{p}=0,031)$ (Tabela 23). A média das mães que já haviam passado pela experiência de cirurgias anterior foi maior $3,71(\mathrm{dp}=0,55)$ que as das mães que estavam vivenciando essa experiência pela primeira vez 3,31 (dp=0,63), ou seja, esses achados indicam que as mães com experiência prévia utilizam mais dessas estratégias para enfrentar a situação com a criança que as outras mães.

As variáveis: estado civil, profissão, tempo de internação, conhecimento sobre a data da cirurgia e grau de escolaridade não apresentou correlação significativa quanto à utilização de estratégias de CRE.

Através da análise entre as variáveis os achados demonstraram interação entre CRE positivo $\mathrm{x}$ idade das mães x já ter realizado cirurgias anteriores, o que demonstram que mães que já 
haviam passado pela experiência de cirurgia anteriormente com idade acima de 36 anos utilizam mais de estratégias de CRE em relação às mães que aguardavam pelo primeiro procedimento e com faixa etária inferior (Gráfico 8).

No instrumento WHOQOL-bref foram analisadas as mesmas variáveis que no instrumento CRE-breve de modo independente. Houve diferença significativa $\mathrm{p}<0,05$ em relação à idade das mães ( $\mathrm{p}=0,031$ ) (Tabela 32) no domínio 2 (psicológico). A interação entre essas duas variáveis demonstram que neste domínio (psicológico) as mães acima de 36 anos possuem média superior 16,81 (dp=1,78) as mães de faixa etária inferior (Tabela 32 e Gráfico 9).

$\mathrm{O}$ domínio 3 (relações sociais) apresentou diferença significativa $\mathrm{p}<0,05$ em relação às variáveis: estado civil $(\mathrm{p}=0,045)$ e ter profissão/trabalhar $(\mathrm{p}=0,031)$ (Tabela 33). Constatou-se colinearidade entre estas duas variáveis demonstrando assim que das mulheres que declararam trabalhar, 60\% tinham companheiro e as que declararam não trabalhar 82\% tinham companheiro. Neste domínio (relações sociais) as mulheres que declararam não trabalhar 17,21 (dp=3,03) apresentaram média superior as que declararam trabalhar 15,09 $(\mathrm{dp}=3,52)$ (Tabela 33 e Gráfico $10)$.

No domínio 4 (meio ambiente) houve diferença significativa $\mathrm{p}<0,05$ em relação à variável estado civil ( $\mathrm{p}=0,002)$ (Tabela 34). A interação entre este domínio e estado civil demonstrou que as mães que declararam ter companheiro ou serem casadas obtiveram média superior 14,41 $(d p=2,32)$ em comparação as solteiras, viúvas ou separadas 11,92 (dp=2,30) (Tabela 34 e Gráfico 11). 


\section{Conclusão}

É crescente o número de publicações investigando os efeitos da espiritualidade/religiosidade no contexto de saúde. Existem diversos estudos focando pacientes adultos, no entanto, em casos de pacientes pediátricos e em relação a seus cuidadores pouco tem sido explorado em relação a utilização de estratégias de coping religioso/espiritual.

O presente estudo demonstrou através dos achados que ser mãe de uma criança portadora de doença crônica, como a cardiopatia congênita, é um fato estressante que afeta não só a criança como toda a família devido às freqüentes internações, mudança na rotina, ansiedade com a cirurgia, medo da perda, entre outros. Para enfrentar essa situação as mães declararam buscar em Deus força, conforto e apoio, utilizando-se assim de estratégias positivas de enfrentamento, e que mães acima de 36 anos, que já viveram a experiência de procedimento cirúrgico com a criança as utilizam mais do que as mães de faixa etária inferior que estão aguardando o primeiro procedimento cirúrgico.

Tanto a qualidade de vida assim como a percepção sobre o estado de saúde dessas mães foram consideradas satisfatórias, porém é importante ressaltar que 46 (95,8\%) das mães declararam ter sentimentos negativos tais como: mau humor, ansiedade e depressão o que indica haver algum sofrimento psíquico que deve ser investigado em futuras pesquisas.

As mães acima de 36 anos também obtiveram média superior as mães com idade inferior no domínio psicológico, enquanto que no domínio relações sociais já as mulheres que declararam trabalhar e não terem companheiros ou serem casadas obtiveram média inferior que as que declararam não trabalhar e terem companheiros. No domínio meio ambiente as mães sem companheiro também tiveram média inferior as companheiros ou casadas.

Assim sendo podemos concluir que as mães de crianças com cardiopatia congênita utilizam de coping religioso espiritual - positivo para lidar com os eventos estressante, e que essas estratégias se correlacionam com os domínios de qualidade de vida. O estudo apontou a utilização por parte dessas mães de estratégias positivas de religiosidade/espiritualidade para administrar o estresse gerado e que estas estão correlacionadas com qualidade de vida. 


\section{Referências Bibliográficas}

1- Paiva GJ. AIDS, psicologia e religião: O estado da questão na literatura psicológica. Psicologia: Teoria e Pesquisa. 1998; 14(1): 27-34.

2- Folkman S. Personal control and stress and coping processes: A theorical analysis. Journal of Personality and Social Psychology. 1984; 46(4): 839-852.

3- Antoniazzi AS, Dell'Aglio DD, Bandeira DR. O conceito de coping: uma revisão teórica. Estudos de Psicologia. 1998; 3(2): 273-294.

4- Folkman S. An analysis of coping in a middle-aged community sample. Journal of Health and Social Behavior. 1980; 21: 219-239.

5- Panzini RG. Escala de Coping religioso - Espiritual (Escala CRE): tradução, adaptação e validação da escala RCOPE, abordando relações com saúde e qualidade de vida [tese]. Universidade Federal do Rio Grande do Sul: Porto Alegre; 2004.

6- Compas BE. Coping with stress during childhood and adolescence. Psychological Bulletin. 1987; 101(3): 393-403.

7- Coyne JC, Delongis A. Going beyond social support: The role of social relationship in adaptation. Journal of Consulting and Clinical Psychology. 1986; 54(4): 454-460.

8- O'Brien TB, DeLongis A. The interactional contexto of problem-, emotion-, and relationshipfocused doping: The role of the big five personality factors. Journal of Personality and Social Psychology. 1996; 46: 655-668.

9- Gutierrez, P. L. Doenças Crônicas na Infância. In: Marcondes E, Vaz FAC, Ramos JLA, Okay Y. Pediatria Básica. 8 ed. São Paulo: Sarvier; 1991. p.788-90. 
10- Hamlett KW, Pellegrini DS, Katz K. Childhood chronic illness as a family stressor. Journal of Pediatric Psychology. 1992; 17(1): 33-47.

11- Forte TL, Sato CM. Programa família participante: a humanização hospitalar como resgate da dignidade, exercício da cidadania e transformação da gestão hospitalar. Curitiba: Associação Hospitalar de Proteção a Infância Dr Raul Carneiro/ Hospital Pequeno Príncipe; 2006.

12- Ribeiro C, Madeira AMF. O significado de ser mãe de um filho portador de cardiopatia: um estudo fenomenológico. Rev Esc Enferm USP. 2006; 40(1): 42-9.

13- Muscari ME. Coping with chronic illness nursing knowledge and compassion can empower ill or disabled teens. Am J. Nurs. 1998; 98(9): 20-2.

14- Castro EK, Piccinini CA. Implicações da Doença Orgânica Crônica na Infância para as Relações Familiares: Algumas Questões Teóricas. Psicologia: Reflexão e Crítica. 2002; 15(3): 625-635.

15- Clark SM, Miles MS. Conflicting responses: The experiences of fathers of infants diagnosed with severe congenital heart disease. Journal of the Society of Pediatric Nurses. 1999; 4(1): 7-14.

16- Goldberg S, Gotowiec A, Symmons RJ. Infant - mother attachment and behavior problems in healthy and chronically ill preschoolers. Development and psychopathology. 1995; 7(2): 267282.

17- Hoffman RG, Rodrigues JR, Andrés JM, Novak DA. Moderating effect of family functioning on the social adjustment of children liver disease. Children's Health Care. 1995; 24(2): 107-117.

18- Zahr LK, El Haddad A. Temperament and chronic illness in Egyptian children. International Journal Intercultural relations. 1998; 22(4): 453-465. 
19- Santana MVT. Cardiopatias congênitas no recém-nascido: diagnósticos e tratamentos. São Paulo: Ateneu; 2000.

20- Leite DL, Miziara H, Veloso M. Malformações cardíacas congênitas em necropsias pediátricas: características, associações e prevalência. Arq. Brás. Cardiol. 2010; 94(3): 294-299.

21- Marcondes E, Vaz FAC, Ramos JLA, Okay Y. Cardiopatias Congênitas Informações Gerais e Cardiopatias Congênitas Acianogênicas. In: Mesquita SMF, Ikari NM, Ebad M. Tomo III Pediatria Clínica Especializada. São Paulo: Sarvier; 2005. p.464-472.

22- Biscegli JM. Tratamento cirúrgico das cardiopatias congênitas acianogênicas e cianogênicas. Rev Soc Cardiol. 2002; 12(5): 763-775.

23- Davis CC, Brown RT, Bakeman R, Campbell R. Psychological adaptation and adjustment of mothers of children with congenital heart disease: stress, coping, and family functioning. J Pediatr. Psychol. 1998; 23(4): 219-228.

24- Simões S, Pires A, Barroca A. Comportamento parental face à cardiopatia congênita. Aná. Psicológica. 2010; 28 (4): 619-30.

25- Prates PR. Pequena história da cirurgia cardíaca: e tudo aconteceu diante de nossos olhos. Rev Brás Cardiol. 1996; 66(1): 329-337.

26- Wennevold A, Rygg I, Lauridsen Jr. Fourteen-to-nineteen-year follow-up after corrective repair for tetralogy of Fallot. Scand J Thorac Cardiovasc Surg. 1982; 16(1): 41-5.

27- Ebaid M, Azeka E, Ikari NM, Atik E. Cardiopatias congênitas: classificação e aproximação diagnóstica. Rev Soc Cardiol Estado de São Paulo. 1993; 3(1): 9-36. 
28- Damas BGB. Necessidade de Informação e suporte aos pais de crianças portadoras de cardiopatias congênitas [tese]. São Paulo: Escola de Enfermagem da USP; 2008.

29- Souza DSB. Avaliação de Estresse e Enfrentamento das Mães de Crianças com Cardiopatias Congênitas [tese]. Botucatu: Universidade Estadual Júlio de Mesquita Filho, UNESP; 2010.

30- Aiello VD, Canêo LF, Jatene MB, Riso AA, Afiune JY, Leal SMB, Lopes AAB, Oliveira SA, Ramires JAF, Barbero-Marcial M. Uma proposta para nomenclatura dos defeitos congênitos do sistema cardiovascular. Rev Brás Cir Cardiovasc. 2002; 17(1): 1-5.

31- Anders JC, Lima RAG. Crescer como transplantado de medula óssea: repercussões na qualidade de vida de crianças e adolescentes. Rev Latino-am Enfermagem. 2004; 12(6): 866-74.

32- Kohlsdorf M, Costa JAL. Estratégias de enfrentamento de pais de crianças em tratamento com câncer. Estud.psicol. 2008; 25(3): 417-429.

33- Ramos IC, Queiroz MV, Jorge MS, Santos ML. Portador de IRC em hemodiálise: significados da experiência vivida na implementação do cuidado. Acta Sci Health Sci. 2008; 30(1): 73-9.

34- Yoshihara C, Watanabe CE, Romano BW. Interferência do atendimento psicológico e grupal nas estratégias de enfrentamento (coping) dos acompanhantes de crianças cardíacas internadas. Volume 85, suplemento IV. (2005).

35- Castro E K, Piccinini CA. A experiência de maternidade de mães de crianças com e sem doença crônica no segundo ano de vida. Estudos de Psicologia. 2004; 9(1): 89-99.

36- Crochik LS, Bertani IF, Barbero-Marcial M. Crianças Operadas e condições familiares. O que muda? Estudo no Instituto do Coração - HCFMUSP. Rev. Bras. Cir. Cardiovasc. 1995; 10(4): 206-10. 
37- Steele RG, Dreyer ML, Phipps S. Patterns of maternal distress among children with cancer and their association with child emotional and somatic distress. Journal of Pediatric Psychology. 2004; 29 (7): 507-517.

38- Silva FM, Correa I. Doença crônica na Infância: vivência do familiar na hospitalização da criança. Rev. Min. Enf. 2006; 10(1): 18-23.

39- Yali AM, Lobel M. Coping and distress in pregnancy: an investigation of medically high risk women. J Psychosom Obstet Gynaecol. 1999; 20(1): 39-52.

40- Benute GRG, Nonnenmacher D, Evangelista FM, Lopes LM, Lucia MCS, Zugaib M. Cardiopatia fetal e estratégias de enfrentamento. Rev. Brás. Ginecol. Obstet. 2011; 33(9): 227-33.

41- Tix AP, Frazier PA. The use of religious coping during stressful life events: main effects, moderation, and mediation. J Consult Clin Psychol. 1998; 66 (2): 411-422.

42- Pargament KI. The psychology of religion and coping: theory, research, practice. New York: Guilford Press; 1997.

43- Koenig HG. Religion and Medicine IV: religion, physical health, and clinical implications. Int J Psychiatry Med. 2001; 31(2): 199-2.

44- McIntosh D, Spilka B. Religion and physical health: the role of personal faith and control beliefs. Rev S. Study Relig. 1990; 2: 167-194.

45- Koenig HG, Larson DB, Larson SS. Religion and coping with serious medical illness. Ann Pharmacother. 2001; 35(3): 352-359.

46- Tepper L, Rogers SA, Coleman EM, Malony HN. The prevalence of religious coping among persons persistent mental illness. Psychiatr Srv. 2001; 52: 660-665. 
47- Koenig HG, Pargament KI, Nielsen J. Religious coping and health status in medical ill hospitalized older adults. J Nerv Ment Dis. 1998; 186(9): 513-521.

48- Panzini RG, Rocha NS, Bandeira DR, Fleck MPA. Qualidade de Vida e Espiritualidade. Rev Psiquiatr Clin. 2007; 34 (1): 105-115.

49- Organização Mundial da Saúde. Constituição OMS. (1946). New York.

50- Lopes DPLO. A organização familiar e o acontecer do tratamento da criança com câncer. In: Valle ERM. Psico-oncologia pediátrica. Campinas: Editora Psy; 2001. p.13-74.

51- Mensorio MS, Costa JAL. Estratégias de enfrentamento de pais de crianças em tratamento de câncer. In: XXXVIII Reunião Anual da Sociedade Brasileira de Psicologia. (2008).

52- Mensorio MS, Kohlsdorf M, Costa JAL. Cuidadores de crianças e adolescentes com leucemia: análise de estratégias de enfrentamento. Psicol. Rev . 2009; 15(1): 158-176.

53- King M, Speck P, Thomas A. Spiritual and religious beliefs in acute illness: is this a feasible area for study? Soc Sci Med. 1994; 38(4): 631-6.

54- McSherry W, Phil M, Cash K, Ross L. Meaning of spirituality: implications for nursing practice. J Clin Nurs. 2004; 13(8): 934-41.

55- Warner-Robbins CG, Bomar PJ. Family spirituality and religion. Foundations of nursing care of families in family health promotion. In: Bomar PJ. Promoting health in families. Applying family research and theory to nursing practice. Philadelphia: Saunders; 2004. p.187-221.

56- Como JM. Spiritual practice: a literature review related to spiritual health and health outcomes. Holist Nurs Pract. 2007; 21(5): 224.36. 
57- De Paula ES, Nascimento LC, Rocha SMM. Religião e espiritualidade: experiência de famílias de crianças com Insuficiência Renal Crônica. Rev Bras Enferm. 2009; 62(1): 100-6.

58- Valcanti CC, Chaves ECL, Mesquita AC, Nogueira DA, Carvalho EC. Coping religioso/espiritual em pessoas com doença renal crônica em tratamento hemodialítico. Rev Esc Enferm USP. 2012; 46(4): 838-45.

59- Ferriss AL. Religion and the quality of life. Journal of Happiness Studies. 2002; 3(3): 199215.

60- Peterman AH, Fitchett G, Brady MJ, Hernandez I, Cella D. Measuring spritual well-being in people with cancer: the Functional Assessment of Chronic Illness Therapy - Spiritual Well-Being Scale (FACIT - Sp). Annais of Behavioral Medicine. 2002; 24(1): 49-58.

61- Paloma MM, Pendleton BF. Exploring types of prayer and quality of life: a research note. Review of Religious Research. 1989; 31: 46-53.

62- Cella D, Brady MJPAH, Fitchett GA. Case for including spirituality in quality of life measurement in oncology. Psycho-oncology. 1999; 8: 417-428.

63- Gioiella ME, Berkman B, Robinson M. Spirituality and quality of life in gynecologic oncology patients. Cancer Practice. 1998; 6(6): 333-338.

64- Moreira-Almeida A, Neto FL, Koenig HG. Religious and mental health: a review. Rev Bras Psiquiatr. 2006; 28(3): 242-50.

65- Rocha NS, Fleck MPA. Avaliação de qualidade de vida e importância dada a espiritualidade/religiosidade/crenças pessoais (SRPB) em adultos com e sem problemas crônicos da saúde. Rev. Psiquiatr.Clín. 2011; 38(1): 19-23. 
66- Spitzer WO, Dobson AJ, Hall J, Chesterman E, Levi J, Sphepherd R, Battista RN, Catchlove B. Measuring the quality of life of cancer patients. Journal of Chronic Diseases. 1981; 34: 585597.

67- Pargament KI, Smith BW, Koenig HG, Peres LM. Patterns of positive and negative religious coping major life stressors. Journal for the Scientific Study of Religion. 1998; 37(4): 710-724.

68- Faria JB, Seidl EMF. Religiosidade e enfrentamento em contextos de saúde e doença: revisão da literatura. Psicol.Reflex.Crit. 2005; 18(3): 381-389.

69- Panzini RG, Bandeira DR. Escala de Coping Religioso Espiritual (Escala CRE): elaboração e validação do construto. Psicologia em Estudo. 2005; 10(3): 507-16.

70- Pargament KL, Koening HG, Perez LM. The many methods of religious coping: Development and initial validation of the RCOPE. Journal of Clinical Psychology. 2000; 56(4): $519-543$.

71- Panzini RG, Maganha C, Rocha NS, Bandeira DR, Fleck MPA. Validação brasileira do Instrumento de Qualidade de Vida/Espiritualidade, religião e crenças pessoais. Rev. Saúde Pública. 2011; 45(1): 153-65.

72- Fleck MPA, Louzada S, Xavier M, Chachamovich E, Vieira G, Santos L, et al. Aplicação da versão em protuguês do instrumento abreviado de avaliação da qualidade de vida "WHOQOLBref’. Rev Saúde Pública. 2000; 34: (2) 178-83.

73- Aguiar MIF, Farias DR, Pinheiro ML, Chaves ES, Rolim ILTP, Almeida PC. Qualidade de Vida de Pacientes Submetidos ao Transplante Cardíaco: Aplicação da Escala Whoqol-Bref. Arq Brás Cardiol. 2011; 96(1): 60-67. 
74- Albuquerque SML. Qualidade de Vida do Idoso. São Paulo: Casa do Psicólogo Livraria e Editora; 2003.

75- Fleck MPA. O instrumento de avaliação de qualidade de vida da Organização Mundial da Saúde (WHOQOL - 100): características e perspectivas. Ciência \& Saúde Coletiva. 2000; 5(1): 33-38.

76- Pedroso B, Pilatti LA, Gutierrez GL, Picinin CT. Cálculo dos escores e estatística descritiva do WHOQOL-bref através do Microsoft Excel. Revista Brasileira de Qualidade de Vida. 2010; 2(1): 31-36.

77- Maroco J, Marques TG. Qual a fiabilidade do alpha de Cronbach? Questões antigas e soluções modernas? Laboratório de Psicologia. 2006; 4(1): 65-90.

78- Guimarães HP, Avezum A. O impacto da espiritualidade na saúde física. Rev Psiq Clin. 2007; 34(1): 88-94.

79- Maroco J, Marques TG. Qual a fiabilidade do alpha de Cronbach? Questões antigas e soluções modernas? Laboratório de Psicologia. 2006; 4(1): 65-90. 


\begin{abstract}
ANEXOS

\section{I - Termo de Consentimento Livre e Esclarecido para participação em estudo clínico}

Projeto de Pesquisa: Qualidade de Vida e Enfrentamento de situações de estresse, com ferramentas de religiosidade e espiritualidade, em pais de crianças com cardiopatia congênita

Psicóloga Pesquisadora: Cristiane Marcelino

Estamos realizando uma pesquisa com pais de crianças que estão hospitalizadas e que possuem cardiopatia congênita, ou seja, nasceram com algum problema no coração. Gostaríamos de conversar primeiramente sobre a sua experiência aqui no hospital, período de permanência, sobre sua criança para nos conhecermos um pouco. Também eu gostaria de saber se você possui alguma religião ou se você possui alguma crença, tem pessoas que embora não tenham uma religião propriamente dita acreditam em algo, assim como, também existem pessoas que não acreditam em nada e não possui religião, todas essas pessoas podem contribuir com o nosso estudo.

Caso você concorde e quando se sentir a vontade estaremos gravando o nosso bate papo, não se preocupe, a nossa conversa não será divulgada e toda informação que você der será usada sigilosamente.

Encontraremo-nos em apenas um momento, onde conversaremos sobre questões religiosas, espirituais, sobre o quanto estas questões ajudam ou não você nesta situação que enfrenta com a criança, no seu dia a dia, nas suas relações, ou seja, na sua vida. Também conversaremos um pouco sobre aspectos da sua vida e de como você se sente em algumas situações como: saúde, relacionamentos, atividades diárias, motivação, entre outros aspectos.

A nossa conversa terá duração de aproximadamente 20 minutos e pode ser realizada no horário que você preferir e que não interfira nos seus cuidados com a criança, a combinarmos.

Também caso você não queira continuar com os encontros e desistir de participar do estudo, o seu termo de consentimento pode ser retirado a qualquer momento.

Estarei constantemente à disposição para esclarecer dúvidas sobre a pesquisa.

A sua contribuição é muito importante para nós e desde já agradecemos a sua participação.

São Paulo, de de

Assinatura da mãe:

Assinatura do pesquisador: 


\section{II - Ficha de Dados Sociodemográficos}

1- Nome da mãe da criança:

2- Idade:

[ ] até 26 anos

[ ] de 27 a 37 anos

[ ] acima de 38

3- Estado Civil:

[ ] casada

[ ] amigada

[ ] viúva

[ ] solteira

[ ] divorciada

[ ] separada

4- Profissão:

[ ] $\operatorname{sim}$

[ ] não

5- Estado que reside:

[ ] São Paulo

[ ] Rio de Janeiro

[ ] Minas

[ ] Santa Catarina

[] Ceara

[] Bahia

6- Grau de escolaridade:

[ ] Analfabeta

[ ] Ensino Fundamental

[ ] Ensino Médio

[ ] Ensino Superior

7- Nome da criança: 
8- Idade da criança:

[ ] até 1 ano

[ ] de $1^{\mathrm{a}} 1$ mês até 10 anos

[ ] de 10 anos e 1 mês acima

9 - A criança já realizou alguma cirurgia?

[ ] $\operatorname{sim}$

[ ] não

10- Nesta instituição?

[ ] $\operatorname{sim}$

[ ] não

11- A criança ficou internada outras vezes?

[ ] $\operatorname{sim}$

[ ] não

12- Nesta instituição?

[ ] $\operatorname{sim}$

[ ] não

13- Quando soube do problema da criança?

[ ] durante o pré natal

[ ] no nascimento da criança até 1 ano de vida

[ ] após 1 ano e 1 mês

14- Desde quando esta internada?

[ ] a 1 dia

[ ] de 2 a 7 dias

[ ] de 8 a 15 dias

[ ] mais de 16 dias

13- Sabe qual o diagnóstico da criança?

[ ] $\operatorname{sim}$

[ ] não 
14- Tem outros filhos?

[ ] $\operatorname{sim}$

[ ] não

15- Qual a previsão quanto a realização da cirurgia?

[ ] tem conhecimento sobre a data

[ ] não tem conhecimento sobre a data 


\section{III- Questionário Semi Estruturado sobre Aspectos Religiosos}

1- A sra tem alguma crença ou religião?

[ ] $\operatorname{sim}$

[ ] não

2- Qual religião:

[ ] Católica

[ ] Evangélica

[ ] Testemunha de Jeová

[ ] Mórmons

[ ] Adventista do Sétimo Dia

[ ] Espírita Kardecista

[ ] Espírita Umbandista

3- A quanto tempo a sra freqüenta esta religião?

[ ] desde criança

[ ] a 10 anos

[ ] a 5 anos ou menos

4- Esta crença/religião possui alguma prática religiosa como: jejuar, orar, etc?
[ ] $\operatorname{sim}$
[ ] não

5- Com que freqüência você pratica?
[ ] nunca
[ ] raramente (1 x no mês)
[ ] todos os dias
[ ] frequentemente (2 a 3 vezes na semana)
[ ] as vezes (1 x na semana)

6- Já mudou de religião alguma vez?
[ ] $\operatorname{sim}$
[ ] não

7- Depois que soube do problema da criança percebeu alguma alteração na freqüência desta prática religiosa?

[ ] sim, aumentou

[ ] sim, diminuiu 
[ ] não

8- A sra acredita em Deus?

[ ] $\operatorname{sim}$

[ ] não

9- O que é Deus para a sra?

10- A sra acredita que a sua crença/religião ajudou ou não a enfrentar o problema com seu filho? [ ] sim, ajudou

[ ] não

11- De que maneira?

12- Baseado na sua experiência de que a crença/religião ajudou você a enfrentar estes problemas, que mensagem ou sugestão você daria a outras mães que se encontram nesta situação? 


\title{
IV- Instrumento de Avaliação de Qualidade de Vida WHOQOL - Abreviado
}

\author{
WHOQOL - ABREVIADO \\ Versão em Português \\ PROGRAMA DE SAÚDE MENTAL \\ ORGANIZAÇÃO MUNDIAL DA SAÚDE \\ GENEBRA
}

Coordenação do GRUPO WHOQOL no Brasil

Dr. Marcelo Pio de Almeida Fleck

Professor Adjunto

Departamento de Psiquiatria e Medicina Legal

Universidade Federal do Rio Grande do Sul

Porto Alegre - RS - Brasil

\section{Instruções}

Este questionário é sobre como você se sente a respeito de sua qualidade de vida, saúde e outras áreas de sua vida. Por favor, responda a todas as questões. Se você não tem certeza sobre que resposta dar em uma questão, por favor, escolha entre as alternativas a que lhe parece mais apropriada. Esta, muitas vezes, poderá ser sua primeira escolha.

Por favor, tenha em mente seus valores, aspirações, prazeres e preocupações. Nós estamos perguntando o que você acha de sua vida, tomando como referência as duas últimas semanas . Por exemplo, pensando nas últimas duas semanas, uma questão poderia ser:

\begin{tabular}{llllll}
\hline & nada & $\begin{array}{l}\text { muito } \\
\text { pouco }\end{array}$ & médio & muito & completamente \\
\hline $\begin{array}{l}\text { Você recebe dos } \\
\text { outros o apoio de } \\
\text { que necessita? }\end{array}$ & 1 & 2 & 3 & 4 & 5 \\
\cline { 2 - 6 } & & & & & \\
\hline
\end{tabular}


Você deve circular o número que melhor corresponde ao quanto você recebe dos outros o apoio de que necessita nestas últimas duas semanas. Portanto, você deve circular o número 4 se você recebeu "muito" apoio como abaixo.

\begin{tabular}{llllll}
\hline & nada & $\begin{array}{l}\text { muito } \\
\text { pouco }\end{array}$ & médio & muito & completamente \\
\hline $\begin{array}{l}\text { Você recebe dos outros o } \\
\text { apoio de que necessita? }\end{array}$ & 1 & 2 & 3 & 4 & 5 \\
\cline { 2 - 6 } & & & &
\end{tabular}

Você deve circular o número 1 se você não recebeu "nada" de apoio.

Por favor, leia cada questão, veja o que você acha e circule no número e lhe parece a melhor resposta.

\begin{tabular}{|c|c|c|c|c|c|c|}
\hline & & $\begin{array}{l}\text { muito } \\
\text { ruim }\end{array}$ & ruim & $\begin{array}{l}\text { nem ruim } \\
\text { nem boa }\end{array}$ & boa & $\begin{array}{l}\text { muito } \\
\text { boa }\end{array}$ \\
\hline \multirow{3}{*}{1} & \multirow{3}{*}{$\begin{array}{l}1 \text { Como você } \\
\text { avaliaria sua } \\
\text { qualidade de } \\
\text { vida? }\end{array}$} & 1 & 2 & 3 & 4 & 5 \\
\hline & & & & & & \\
\hline & & $\begin{array}{l}\text { muito } \\
\text { insatisfeito }\end{array}$ & insatisfeito & $\begin{array}{l}\text { nem satisfeito } \\
\text { nem } \\
\text { insatisfeito }\end{array}$ & satisfeito & $\begin{array}{l}\text { muito } \\
\text { satisfeito }\end{array}$ \\
\hline \multirow[t]{2}{*}{2} & \multirow{2}{*}{$\begin{array}{l}\text { Quão } \\
\text { satisfeito(a) } \\
\text { você está com } \\
\text { a sua saúde? }\end{array}$} & 1 & 2 & 3 & 4 & 5 \\
\hline & & & & & & \\
\hline
\end{tabular}

As questões seguintes são sobre o quanto você tem sentido algumas coisas nas últimas duas semanas

\begin{tabular}{|c|c|c|c|c|c|c|}
\hline & & nada & $\begin{array}{l}\text { muito } \\
\text { pouco }\end{array}$ & $\begin{array}{l}\text { mais ou } \\
\text { menos }\end{array}$ & bastante & extremamente \\
\hline 3 & $\begin{array}{l}\text { Em que medida } \\
\text { você acha que sua } \\
\text { dor (física) impede } \\
\text { você de fazer o } \\
\text { que você precisa? }\end{array}$ & 1 & 2 & 3 & 4 & 5 \\
\hline 4 & $\begin{array}{l}\text { O quanto você } \\
\text { precisa de algum } \\
\text { tratamento médico } \\
\text { para levar sua vida } \\
\text { diária? }\end{array}$ & 1 & 2 & 3 & 4 & 5 \\
\hline
\end{tabular}




\begin{tabular}{|c|c|c|c|c|c|c|}
\hline 5 & O quanto você & 1 & 2 & 3 & 4 & 5 \\
\hline \multirow[t]{2}{*}{6} & \multirow{2}{*}{$\begin{array}{l}\text { Em que medida } \\
\text { você acha que a } \\
\text { sua vida tem } \\
\text { sentido? }\end{array}$} & 1 & 2 & 3 & 4 & 5 \\
\hline & & & & & & \\
\hline \multirow[t]{2}{*}{7} & \multirow{2}{*}{$\begin{array}{l}\text { O quanto você } \\
\text { consegue se } \\
\text { concentrar? }\end{array}$} & 1 & 2 & 3 & 4 & 5 \\
\hline & & & & & & \\
\hline \multirow[t]{2}{*}{8} & \multirow{2}{*}{$\begin{array}{l}\text { Quão seguro(a) } \\
\text { você se sente em } \\
\text { sua vida diária? }\end{array}$} & 1 & 2 & 3 & 4 & 5 \\
\hline & & & & & & \\
\hline 9 & $\begin{array}{l}\text { Quão saudável é o } \\
\text { seu ambiente } \\
\text { físico (clima, } \\
\text { barulho, poluição, } \\
\text { atrativos)? }\end{array}$ & 1 & 2 & 3 & 4 & 5 \\
\hline
\end{tabular}

As questões seguintes perguntam sobre quão completamente você tem sentido ou é capaz de fazer certas coisas nestas últimas duas semanas.

\begin{tabular}{|c|c|c|c|c|c|c|}
\hline & & nada & $\begin{array}{l}\text { muito } \\
\text { pouco }\end{array}$ & médio & muito & completamente \\
\hline 10 & $\begin{array}{l}\text { Você tem energia } \\
\text { suficiente para seu } \\
\text { dia-a-dia? }\end{array}$ & 1 & 2 & 3 & 4 & 5 \\
\hline 11 & $\begin{array}{l}\text { Você é capaz de } \\
\text { aceitar sua } \\
\text { aparência física? }\end{array}$ & 1 & 2 & 3 & 4 & 5 \\
\hline 12 & $\begin{array}{l}\text { Você tem dinheiro } \\
\text { suficiente para } \\
\text { satisfazer suas } \\
\text { necessidades? }\end{array}$ & 1 & 2 & 3 & 4 & 5 \\
\hline 13 & $\begin{array}{l}\text { Quão disponíveis } \\
\text { para você estão as } \\
\text { informações que } \\
\text { precisa no seu dia-a- } \\
\text { dia? }\end{array}$ & 1 & 2 & 3 & 4 & 5 \\
\hline 14 & $\begin{array}{l}\text { Em que medida } \\
\text { você tem } \\
\text { oportunidades de } \\
\text { atividade de lazer? }\end{array}$ & 1 & 2 & 3 & 4 & 5 \\
\hline
\end{tabular}


As questões seguintes perguntam sobre quão bem ou satisfeito você se sentiu a respeito de vários aspectos de sua vida nas últimas duas semanas.

\begin{tabular}{|c|c|c|c|c|c|c|}
\hline & & $\begin{array}{l}\text { muito } \\
\text { ruim }\end{array}$ & ruim & $\begin{array}{l}\text { nem ruim } \\
\text { nem bom }\end{array}$ & bom & $\begin{array}{l}\text { muito } \\
\text { bom }\end{array}$ \\
\hline \multirow[t]{3}{*}{15} & & 1 & 2 & 3 & 4 & 5 \\
\hline & $\begin{array}{l}\text { de se } \\
\text { locomover? }\end{array}$ & & & & & \\
\hline & & $\begin{array}{l}\text { muito } \\
\text { insatisfeito }\end{array}$ & insatisfeito & $\begin{array}{l}\text { nem satisfeito } \\
\text { nem insatisfeito }\end{array}$ & satisfeito & $\begin{array}{l}\text { muito } \\
\text { satisfeito }\end{array}$ \\
\hline \multirow[t]{2}{*}{16} & Quão & 1 & 2 & 3 & 4 & 5 \\
\hline & $\begin{array}{l}\text { você está com } \\
\text { o seu sono? }\end{array}$ & & & & & \\
\hline \multirow[t]{2}{*}{17} & $\begin{array}{l}\text { Quão } \\
\text { satisfeito(a) }\end{array}$ & 1 & 2 & 3 & 4 & 5 \\
\hline & $\begin{array}{l}\text { você está com } \\
\text { sua } \\
\text { capacidade de } \\
\text { desempenhar } \\
\text { as atividades } \\
\text { do seu dia-a- } \\
\text { dia? }\end{array}$ & & & & & \\
\hline \multirow[t]{2}{*}{18} & $\begin{array}{l}\text { Quão } \\
\text { satisfeito(a) }\end{array}$ & 1 & 2 & 3 & 4 & 5 \\
\hline & $\begin{array}{l}\text { você está com } \\
\text { sua } \\
\text { capacidade } \\
\text { para o } \\
\text { trabalho? }\end{array}$ & & & & & \\
\hline \multirow[t]{2}{*}{19} & $\begin{array}{l}\text { Quão } \\
\text { satisfeito(a) }\end{array}$ & 1 & 2 & 3 & 4 & 5 \\
\hline & $\begin{array}{l}\text { você está } \\
\text { consigo } \\
\text { mesmo? }\end{array}$ & & & & & \\
\hline \multirow[t]{2}{*}{20} & Quão & 1 & 2 & 3 & 4 & 5 \\
\hline & $\begin{array}{l}\text { você está com } \\
\text { suas relações } \\
\text { pessoais } \\
\text { (amigos, } \\
\text { parentes, } \\
\text { conhecidos, } \\
\text { colegas)? }\end{array}$ & & & & & \\
\hline
\end{tabular}




\begin{tabular}{|c|c|c|c|c|c|c|}
\hline 21 & $\begin{array}{l}\text { Quão } \\
\text { satisfeito(a) } \\
\text { você está com } \\
\text { sua vida } \\
\text { sexual? }\end{array}$ & 1 & 2 & 3 & 4 & 5 \\
\hline 22 & $\begin{array}{l}\text { Quão } \\
\text { satisfeito(a) } \\
\text { você está com } \\
\text { o apoio que } \\
\text { você recebe } \\
\text { de seus } \\
\text { amigos? }\end{array}$ & 1 & 2 & 3 & 4 & 5 \\
\hline 23 & $\begin{array}{l}\text { Quão } \\
\text { satisfeito(a) } \\
\text { você está com } \\
\text { as condições } \\
\text { do local onde } \\
\text { mora? }\end{array}$ & 1 & 2 & 3 & 4 & 5 \\
\hline 24 & $\begin{array}{l}\text { Quão } \\
\text { satisfeito(a) } \\
\text { você está com } \\
\text { o seu acesso } \\
\text { aos serviços } \\
\text { de saúde? }\end{array}$ & 1 & 2 & 3 & 4 & 5 \\
\hline 25 & $\begin{array}{l}\text { Quão } \\
\text { satisfeito(a) } \\
\text { você está com } \\
\text { o seu meio de } \\
\text { transporte? }\end{array}$ & 1 & 2 & 3 & 4 & 5 \\
\hline
\end{tabular}

As questões seguintes referem-se a com que freqüência você sentiu ou experimentou certas coisas nas últimas duas semanas.

\begin{tabular}{|c|c|c|c|c|c|}
\hline & & nunca & $\begin{array}{l}\text { algumas freqüentemente } \\
\text { vezes }\end{array}$ & $\begin{array}{l}\text { muito } \\
\text { freqüentemente }\end{array}$ & sempre \\
\hline \multirow[t]{2}{*}{26} & \multirow[b]{2}{*}{$\begin{array}{l}\text { Com que } \\
\text { freqüência você } \\
\text { tem sentimentos } \\
\text { negativos tais } \\
\text { como mau } \\
\text { humor, } \\
\text { desespero, } \\
\text { ansiedade, } \\
\text { depressão? }\end{array}$} & 1 & 23 & 4 & 5 \\
\hline & & & & & \\
\hline
\end{tabular}


Alguém lhe ajudou a preencher este questionário?

Quanto tempo você levou para preencher este questionário?

Você tem algum comentário sobre o questionário?

OBRIGADO PELA SUA COLABORAÇÃO 
V - Escala de Coping Religioso-Espiritual Abreviada - Escala CRE-BREVE

ESCALA CRE-BREVE

ESCALA DE COPING RELIGIOSO-ESPIRITUAL ABREVIADA

UNIVERSIDADE FEDERAL DO RIO GRANDE DO SUL

INSTITUTO DE PSICOLOGIA

CURSO DE PÓS-GRADUAÇÃO EM PSICOLOGIA DO DESENVOLVIMENTO

PANZINI \& BANDEIRA, 2005

Estamos interessados em saber se e o quanto você utiliza a religião e a espiritualidade para lidar com o estresse em sua vida. $\mathrm{O}$ estresse acontece quando você percebe que determinada situação é difícil ou problemática, porque vai além do que você julga poder suportar, ameaçando seu bem-estar. A situação pode envolver você, sua família, seu trabalho, seus amigos ou algo que é importante para você.

Neste momento, pense na situação de maior estresse que você viveu nos últimos três anos.

Por favor, descreva-a em poucas palavras:

As frases abaixo descrevem atitudes que podem ser tomadas em situações de estresse.

Circule o número que melhor representa o quanto VOCÊ fez ou não o que está escrito em cada frase para lidar com a situação estressante que você descreveu acima. Ao ler as frases, entenda o significado da palavra Deus segundo seu próprio sistema de crença (aquilo que você acredita).

Exemplo:

Tentei dar sentido à situação através de Deus.

(1) nem um pouco (2) um pouco (3) mais ou menos (4) bastante (5) muitíssimo

Se você não tentou, nem um pouco, dar sentido à situação através de Deus, faça um círculo no número (1)

Se você tentou um pouco, circule o (2)

Se você tentou mais ou menos, circule o (3)

Se você tentou bastante, circule o (4)

Se você tentou muitíssimo, circule o (5)

Lembre-se: Não há opção certa ou errada

Marque só uma alternativa em cada questão.

Seja sincero(a) nas suas respostas e não deixe nenhuma questão em branco!

\section{Orei pelo bem-estar de outros}

(1) nem um pouco (2) um pouco (3) mais ou menos (4) bastante (5) muitíssimo

\section{Procurei o amor e a proteção de Deus}

(1) nem um pouco (2) um pouco (3) mais ou menos (4) bastante (5) muitíssimo 
3. Não fiz muito, apenas esperei que Deus resolvesse meus problemas por mim

(1) nem um pouco (2) um pouco (3) mais ou menos (4) bastante (5) muitíssimo

\section{Procurei trabalhar pelo bem-estar social}

(1) nem um pouco (2) um pouco (3) mais ou menos (4) bastante (5) muitíssimo

\section{Procurei ou realizei tratamentos espirituais}

(1) nem um pouco (2) um pouco (3) mais ou menos (4) bastante (5) muitíssimo

\section{Procurei em Deus força, apoio e orientação}

(1) nem um pouco (2) um pouco (3) mais ou menos (4) bastante (5) muitíssimo

7. Senti insatisfação com os representantes religiosos de minha instituição

(1) nem um pouco (2) um pouco (3) mais ou menos (4) bastante (5) muitíssimo

8. Pedi a Deus que me ajudasse a encontrar um novo propósito na vida

(1) nem um pouco (2) um pouco (3) mais ou menos (4) bastante (5) muitíssimo

9. Imaginei se Deus permitiu que isso me acontecesse por causa dos meus erros

(1) nem um pouco (2) um pouco (3) mais ou menos (4) bastante (5) muitíssimo

10. Realizei atos ou ritos espirituais (qualquer ação especificamente relacionada com sua crença: sinal da cruz, confissão, jejum, rituais de purificação, citação de provérbios, entoação de mantras, psicografia, etc.)

(1) nem um pouco (2) um pouco (3) mais ou menos (4) bastante (5) muitíssimo

11. Tive dificuldades para receber conforto de minhas crenças religiosas

(1) nem um pouco (2) um pouco (3) mais ou menos (4) bastante (5) muitíssimo

12. Fiz o melhor que pude e entreguei a situação a Deus

(1) nem um pouco (2) um pouco (3) mais ou menos (4) bastante (5) muitíssimo

13. Convenci-me que forças do mal atuaram para tudo isso acontecer

(1) nem um pouco (2) um pouco (3) mais ou menos (4) bastante (5) muitíssimo 


\section{Pratiquei atos de caridade moral e/ou material}

(1) nem um pouco (2) um pouco (3) mais ou menos (4) bastante (5) muitíssimo

15. Procurei me aconselhar com meu guia espiritual superior (anjo da guarda, mentor, etc)

(1) nem um pouco (2) um pouco (3) mais ou menos (4) bastante (5) muitíssimo

16. Voltei-me a Deus para encontrar uma nova direção de vida

(1) nem um pouco (2) um pouco (3) mais ou menos (4) bastante (5) muitíssimo

17. Tentei lidar com meus sentimentos sem pedir a ajuda de Deus

(1) nem um pouco (2) um pouco (3) mais ou menos (4) bastante (5) muitíssimo

18. Tentei proporcionar conforto espiritual a outras pessoas

(1) nem um pouco (2) um pouco (3) mais ou menos (4) bastante (5) muitíssimo

19. Fiquei imaginando se Deus tinha me abandonado

(1) nem um pouco (2) um pouco (3) mais ou menos (4) bastante (5) muitíssimo

20. Pedi para Deus me ajudar a ser melhor e errar menos

(1) nem um pouco (2) um pouco (3) mais ou menos (4) bastante (5) muitíssimo

21. Pensei que o acontecido poderia me aproximar mais de Deus

(1) nem um pouco (2) um pouco (3) mais ou menos (4) bastante (5) muitíssimo

22. Não tentei lidar com a situação, apenas esperei que Deus levasse minhas preocupações embora

(1) nem um pouco (2) um pouco (3) mais ou menos (4) bastante (5) muitíssimo

23. Senti que o mal estava tentando me afastar de Deus

(1) nem um pouco (2) um pouco (3) mais ou menos (4) bastante (5) muitíssimo

24. Entreguei a situação para Deus depois de fazer tudo que podia

(1) nem um pouco (2) um pouco (3) mais ou menos (4) bastante (5) muitíssimo

25. Orei para descobrir o objetivo de minha vida

(1) nem um pouco (2) um pouco (3) mais ou menos (4) bastante (5) muitíssimo 


\section{Fui a um templo religioso}

(1) nem um pouco (2) um pouco (3) mais ou menos (4) bastante (5) muitíssimo

27. Busquei proteção e orientação de entidades espirituais (santos, espíritos, orixás, etc)

(1) nem um pouco (2) um pouco (3) mais ou menos (4) bastante (5) muitíssimo

\section{Imaginei se minha instituição religiosa tinha me abandonado}

(1) nem um pouco (2) um pouco (3) mais ou menos (4) bastante (5) muitíssimo

\section{Procurei por um total re-despertar espiritual}

(1) nem um pouco (2) um pouco (3) mais ou menos (4) bastante (5) muitíssimo

\section{Confiei que Deus estava comigo}

(1) nem um pouco (2) um pouco (3) mais ou menos (4) bastante (5) muitíssimo

31. Comprei ou assinei revistas periódicas que falavam sobre Deus e questões espirituais

(1) nem um pouco (2) um pouco (3) mais ou menos (4) bastante (5) muitíssimo

\section{Pensei que Deus não existia}

(1) nem um pouco (2) um pouco (3) mais ou menos (4) bastante (5) muitíssimo

\section{Questionei se até Deus tem limites}

(1) nem um pouco (2) um pouco (3) mais ou menos (4) bastante (5) muitíssimo

\section{Busquei ajuda ou conforto na literatura religiosa}

(1) nem um pouco (2) um pouco (3) mais ou menos (4) bastante (5) muitíssimo

\section{Pedi perdão pelos meus erros}

(1) nem um pouco (2) um pouco (3) mais ou menos (4) bastante (5) muitíssimo

\section{Participei de sessões de cura espiritual}

(1) nem um pouco (2) um pouco (3) mais ou menos (4) bastante (5) muitíssimo

\section{Questionei se Deus realmente se importava}

(1) nem um pouco (2) um pouco (3) mais ou menos (4) bastante (5) muitíssimo 


\section{Tentei fazer o melhor que podia e deixei Deus fazer o resto}

(1) nem um pouco (2) um pouco (3) mais ou menos (4) bastante (5) muitíssimo

39. Envolvi-me voluntariamente em atividades pelo bem do próximo

(1) nem um pouco (2) um pouco (3) mais ou menos (4) bastante (5) muitíssimo

40. Ouvi e/ou cantei músicas religiosas

(1) nem um pouco (2) um pouco (3) mais ou menos (4) bastante (5) muitíssimo

41. Sabia que não poderia dar conta da situação, então apenas esperei que Deus assumisse o controle

(1) nem um pouco (2) um pouco (3) mais ou menos (4) bastante (5) muitíssimo

42. Recebi ajuda através de imposição das mãos (passes, rezas, bênçãos, magnetismo, reiki, etc.)

(1) nem um pouco (2) um pouco (3) mais ou menos (4) bastante (5) muitíssimo

43. Tentei lidar com a situação do meu jeito, sem a ajuda de Deus

(1) nem um pouco (2) um pouco (3) mais ou menos (4) bastante (5) muitíssimo

44. Senti que meu grupo religioso parecia estar me rejeitando ou me ignorando

(1) nem um pouco (2) um pouco (3) mais ou menos (4) bastante (5) muitíssimo

45. Participei de práticas, atividades ou festividades religiosas ou espirituais

(1) nem um pouco (2) um pouco (3) mais ou menos (4) bastante (5) muitíssimo

46. Procurei auxílio nos livros sagrados

(1) nem um pouco (2) um pouco (3) mais ou menos (4) bastante (5) muitíssimo

47. Tentei mudar meu caminho de vida e seguir um novo - o caminho de Deus

(1) nem um pouco (2) um pouco (3) mais ou menos (4) bastante (5) muitíssimo

48. Culpei Deus pela situação, por ter deixado acontecer

(1) nem um pouco (2) um pouco (3) mais ou menos (4) bastante (5) muitíssimo 
49. Refleti se não estava indo contra as leis de Deus e tentei modificar minha atitude

(1) nem um pouco (2) um pouco (3) mais ou menos (4) bastante (5) muitíssimo

\section{OBRIGADO POR PARTICIPAR!}




\section{VI - Descrição das respostas da Questão: “O que é Deus para a sra.?”}

\begin{tabular}{|c|c|}
\hline & Conteúdo \\
\hline Mães & O que é Deus \\
\hline 1 & "é tudo" \\
\hline 2 & "é tudo, resumindo Deus é tudo pra gente, ele que dá força nessas horas de dificuldade" \\
\hline 3 & "é tudo" \\
\hline 4 & "é tudo" \\
\hline 5 & " nosso pai" \\
\hline 6 & “é tudo \\
\hline 7 & "é tudo, é vida, para o meu filho estar vivo hoje é porque Deus existe!" \\
\hline 8 & "como um pai, um pai que ama, zela" \\
\hline 9 & "é tudo" \\
\hline 10 & "é tudo, é aquele que me sustenta, que faz com que eu tenha mais vida, me da força" \\
\hline 11 & “é tudo \\
\hline 12 & "é tudo" \\
\hline 13 & "é tudo, a vida, o ar que respiro, ele que me da força com meu filho com a doença" \\
\hline 14 & "é uma coisa superior que comanda tudo aqui na terra, inclusive a capacidade dos \\
\hline 15 & "é tudo, tudo, o ar, o amor, é tudo" \\
\hline 16 & "é tudo" \\
\hline 17 & "é tudo sem ele não sou nada, sem ele não consigo fazer nada" \\
\hline 18 & "é tudo" \\
\hline 19 & "é tudo" \\
\hline 20 & "é alguém que nunca vi, é um ser superior que pode resolver sua vida basta ter fé" \\
\hline 21 & "é a fé" \\
\hline 22 & "é tudo" \\
\hline 23 & "não sei falar, ele é quem sabe de todas as coisas" \\
\hline 24 & "é tudo onde me apego, me apoio, me fortalece" \\
\hline 25 & "é tudo, não tem como descrever, é o ar que respiro, se estou de pé e graças a ele" \\
\hline 26 & "é tudo" \\
\hline 27 & "é tudo somente ele sabe dos nossos pensamentos, propósitos, ele conhece a mente, \\
\hline 28 & "é tudo, sem ele não somos nada" \\
\hline 29 & "é amor" \\
\hline $30 *$ & "é o nosso criador, a força maior do universo" \\
\hline 31 & "é tudo, é amor, fé, esperança" \\
\hline 32 & "é tudo" \\
\hline 33 & "é tudo é pai, criador do céu e da terra, de tudo que a gente tem" \\
\hline 34 & "é aquela árvore, vejo Deus na natureza, no amor, na criança nascendo, Deus muito \\
\hline 35 & "é tudo sem ele eu não sou nada, meus filhos não são nada, nós não existiríamos" \\
\hline 36 & "é tudo" \\
\hline 37 & "é tudo" \\
\hline 38 & "uma força superior, maior que tudo" \\
\hline 39 & "é tudo" \\
\hline 40 & "é tudo,meu dia, minha noite" \\
\hline
\end{tabular}




\begin{tabular}{l}
41 "é alguém que nos ajuda, não nos abandona, nos abençoa" \\
42 "é tudo" \\
43 "é tudo" \\
44 "é tudo \\
45 "é onde dá força, onde eu tenho esperança" \\
46 "é tudo" \\
47 "é tudo" \\
48 "é um pai" \\
\hline
\end{tabular}


VII - Descrição das respostas da Questão: "De que maneira a sra. acredita que a sua crença/religião ajudou ou não a enfrentar o problema com seu filho?"

\begin{tabular}{|c|c|}
\hline & Conteúdo \\
\hline Mães & De que maneira \\
\hline 1 & "para eu não enlouquecer aqui" \\
\hline 2 & "nas orações que a gente pratica, ele ajuda um pouco" \\
\hline 3 & "nas orações, nos pedidos que recebemos, mesmo que não seja na hora" \\
\hline 4 & "me deu força e ânimo" \\
\hline 5 & "me dando calma, a levo nas reuniões, diminuiu o estresse" \\
\hline 6 & "com força, a gente pedindo né!, só ele mesmo" \\
\hline 7 & "dando suporte, calma, ajudando a enfrentar a situação" \\
\hline 8 & "palavra de conforto, ajudando, dando força" \\
\hline 9 & "nas orações" \\
\hline 10 & "dando força, atendendo meus pedidos" \\
\hline 11 & "nos confortando, acalmando" \\
\hline 12 & "apoio das pessoas, interseções de cada grupo de orações" \\
\hline 13 & "dando força" \\
\hline 14 & "me senti amada por Deus apesar de tudo e que era provação para eu crescer" \\
\hline 15 & “confortando, dando esperança e força, é alguém que podemos confiar" \\
\hline 16 & "dando conforto, calma e confiança" \\
\hline 17 & "me protegendo, me guiando, me da controle, força, proteção" \\
\hline 18 & "dando força" \\
\hline 19 & "acreditando que Deus protege minha filha, vai cura-lá, da força, conforta" \\
\hline 20 & "muita cobrança" \\
\hline 21 & "tudo que eu peço Deus esta me ajudando" \\
\hline 22 & "confortando, dando serenidade, acalmando, dando orientação, esperança, fé" \\
\hline 23 & "só converso com Deus, não tem o que fazer" \\
\hline 24 & "tendo fé, Deus me fortalece, me ajuda a enfrentar e não desabar" \\
\hline 25 & "dando força, ânimo, coragem, vigor para lutar" \\
\hline 26 & "me ajudando, quando fico triste penso em Deus" \\
\hline 27 & "me aliviando, me permitindo desabafar com ele" \\
\hline 28 & "rezando, acreditando nele, não precisa ter religião" \\
\hline 29 & "sensação de acreditar, alguém maior que da auxilio, pensamento positivo" \\
\hline $30 *$ & "dando força" \\
\hline 31 & "dando força, calma, ajudando meu filho a melhorar, me da paz" \\
\hline 32 & "dando força" \\
\hline 33 & "através de outras pessoas que oram para gente, a palavra entregue a nós" \\
\hline 34 & "através da crença na volta de Jesus, caso meu filho morra vou encontrá-lo" \\
\hline 35 & "me comunicando com ele, através das orações ele me da confiança, tranqüilidade" \\
\hline 36 & "dando força" \\
\hline 37 & "dando força" \\
\hline 38 & "dando força" \\
\hline 39 & "muita gente rezando por ele, promessas que estamos fazendo por ele" \\
\hline 40 & "confortando, saber que tem pessoas orando por ela" \\
\hline
\end{tabular}


41 "as irmãs vem orar para ele, conversar com a gente"

42 "me dando força, me ajudando a enfrentar isso"

43 "tendo fé"

44 "dando força, tranqüilidade, conforto, alívio"

45 "dando força, familiares orando por ele, apoio através das palavras da bíblia"

46 "em tudo dando força, paciência"

47 "as pessoas que freqüentam a igreja ajudam, o padre"

48 "aliviando a angústia, dando esperança"

- Mãe que afirmou não ter religião 
VIII - Descrição das respostas da Questão: "Baseado na sua experiência de que a crença/religião ajudou você a enfrentar estes problemas, que mensagem ou sugestão você daria a outras mães que se encontram nesta situação?"

\begin{tabular}{|c|c|}
\hline & Conteúdo \\
\hline Mães & Sugestões \\
\hline 1 & "que elas se apeguem muito com Deus, que nem eu estou me apegando, ele me dá força" \\
\hline 2 & “pra elas praticarem né!, assim participar né! da religião para ajudar no que esta \\
\hline 3 & "buscar Deus" \\
\hline 4 & "fazer o que eu faço, pedir a deus que esteja com ele cubra ele com o teu manto" \\
\hline 5 & "acreditar e pedir a Deus que ele vai ajudar, ele faz tudo" \\
\hline 6 & “tem que ter fé em Deus, s ajuda dele fica impossível, pedi força para enfrentar o \\
\hline 7 & "se apegar com Deus porque só ele pode ajudar" \\
\hline 8 & "aceitar ajuda independente da religião, aceitar oração, ter fé, buscar uma religião" \\
\hline 9 & "ter fé é o mais importante, sem a fé você não agüenta a base estremece" \\
\hline 10 & "não sei é difícil” \\
\hline 11 & “que procurem Deus, peça força a ele, peça ajuda, ele vai te levantar" \\
\hline 12 & “ter fé em Deus porque sem ele a gente não é nada, entregar para ele e tudo vai dar \\
\hline 13 & "não temos que ser de igreja, mas de oração, abrir o coração e pedir que Deus ajuda" \\
\hline 14 & "busque Deus, desabafe com ele, não perder a fé" \\
\hline 15 & "que acreditem em Deus, basta confiar e acreditar em Deus que tudo vai solucionar um \\
\hline 16 & "não perder a fé, esperança, porque com fé a gente consegue tudo" \\
\hline 17 & "crerem em Deus que nada é por acaso" \\
\hline 18 & "não desistirem, não desanimarem, com Deus tudo é possível ele é medico dos médicos" \\
\hline 19 & "que tenham fé em Deus que ele pode tudo, ele da vida e tira a vida, ele pode tudo" \\
\hline 20 & “acreditar sempre em Deus, pedir para ele, porque sem ele não somos nada" \\
\hline 21 & "ter força, coragem, acreditar que você é capaz com a ajuda de Deus" \\
\hline 22 & "freqüentarem a igreja, a casa de Deus que ele ajuda, igualmente ajudou eu e outras \\
\hline 23 & "não desistir, ter fé, confiança, independente da religião Deus nunca abandona" \\
\hline 24 & "não tenho nenhuma sugestão" \\
\hline 25 & "ter fé, pedir para Deus olhar seu filho e focar nele porque ai você se fortalece" \\
\hline 26 & "buscar Deus" \\
\hline 27 & "não se desesperar e acreditar em Deus" \\
\hline 28 & "ser forte, somente Deus vai nos ajudar, consolar e aliviar a angústia através palavras" \\
\hline 29 & "acreditar em Deus, se apegar a ele, ter pensamentos positivos, que da tudo certo" \\
\hline $30 *$ & "independente da religião cada um tem que seguir seu coração" \\
\hline 31 & "para manterem a calma, pedir mais, rezar, confiar e ter fé" \\
\hline 32 & "para ter força, procurar Deus, alguma religião" \\
\hline 33 & "independente da religião deve buscar Deus, acreditar em Deus, procurar Deus" \\
\hline 34 & "para terem fé em Deus, orar bastante, vigiar, confiar em Deus, jejuar" \\
\hline 35 & "que elas conversem com Deus, que busquem Deus" \\
\hline 36 & "que orem, que acreditem" \\
\hline 37 & "acreditem em Deus, peça a ele, tenham fé" \\
\hline 38 & “entregar nas mãos de Deus" \\
\hline 39 & "ter fé e acima de tudo Deus, se não for ele para dar força acho que não tenho" \\
\hline
\end{tabular}


40 "se apegar a alguma coisa independente de qual for a religião"

41 "confiar em Deus, pedir a ajuda dele, entregar nas mãos de Deus"

42 "acreditar que Deus vai ajudar, que vai dar tudo certo"

43 "para ter muita fé em Deus e confiar nos médicos"

44 "ter fé, pedir com o coração aliviado"

45 "não desacreditar nunca, pedir para Deus dar força, e aliviar nos momentos de sufoco"

46 "se apegar com Deus, acreditar e ter fé"

47 "procurar Deus, as pessoas da igreja que confortam"

48 "ter muita força, muita fé e orar bastante"

* Mãe que afirmou não ter religião 


\section{IX - Descrição das respostas que pede a descrição da situação que a mãe vivei de maior estresse nos últimos três anos}

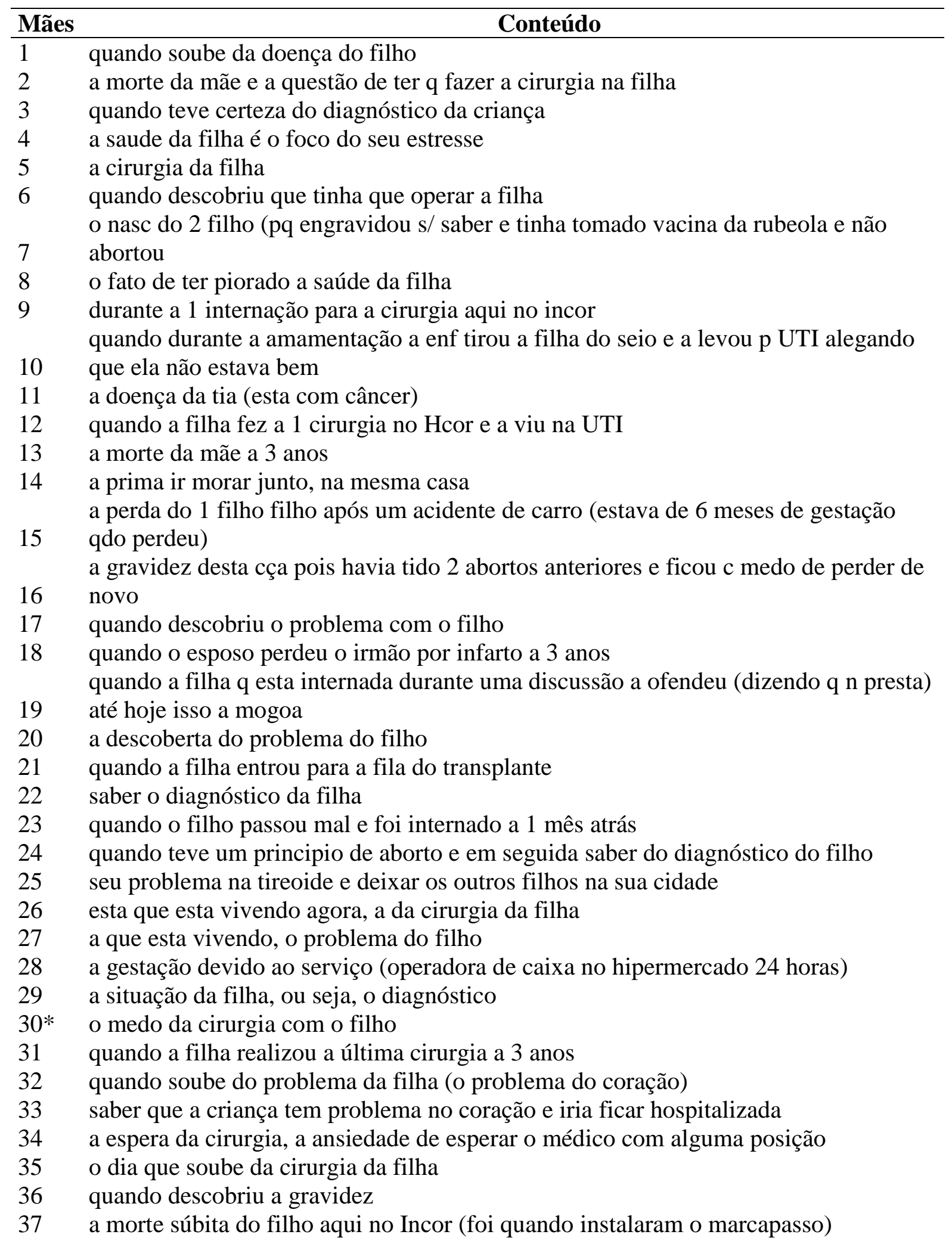


38 a morte do pai

39 a questão com o filho, a possibilidade da cirurgia

40 foi a filha mais velha assumir ser homossexual

41 a situação do filho em relação a ter que fazer cirurgia

42 o sequestro das filha mais velha (ela estava junto) quando engravidou tomando anticoncepcional e depois descobriu que a criança(a

43 internada) era down

44 o problema do filho

45 quando o filho fez a primeira cirurgia pois ele veio $\mathrm{p}$ consulta e ficou $\mathrm{p}$ cirurgia o filho ter roubado um cel do delegado e ser recolhido pelo conselho tutelar semana

46 passada

47 o fato de estar internado pela terceira vez e $n$ conseguir fazer a cirurgia

48 o problema com a filha

* Mãe que afirmou não ter religião 